*ak RMIS View/Frint Document Cover Sheet tow

This document was retrieved from the Documentation and Records Manaqement (DRM) ISEARCH System. It is intended for Information only and may not be the most recent or updated version. Contact a Document Service Center (see Hanford Info for locations) if you need additional retrieval information.

Accession \#: D196022110

Document \#: SD-SNF-DA-016

Title/Desc:

305 BLDG 2 TON BRIDGE CRANE \& MONORAIL ASSEMBLY ANALYSIS

Pages: 56 


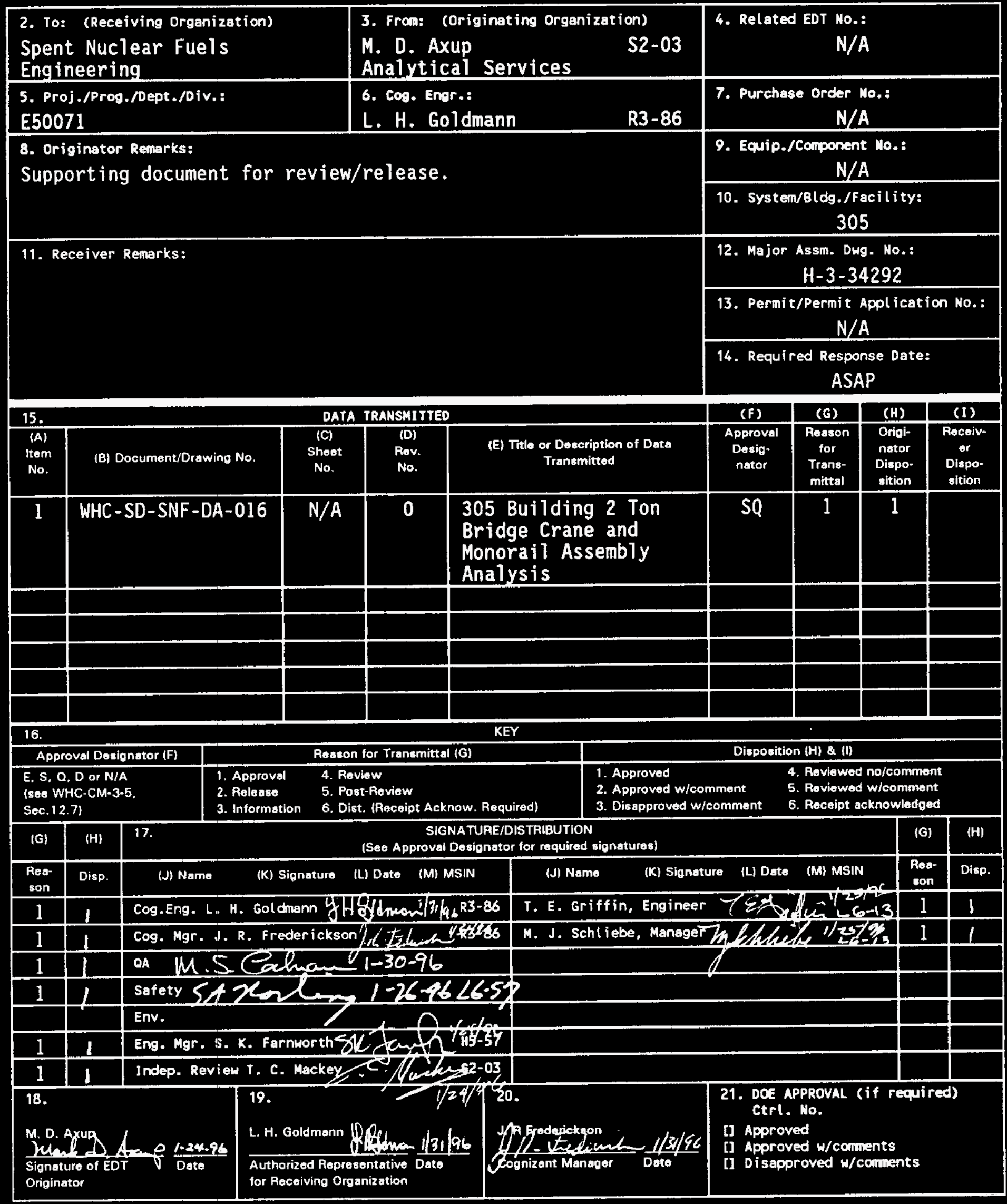




\title{
305 BUILDING 2 TON BRIDGE CRANE AND MONORAIL ASSEMBLY ANALYSIS
}

M. D. Axup

ICF KH, Richland, WA 99352

U.S. Department of Energy Contract DE-AC06-87RL10930

\author{
EDT/ECN: 614408 \\ Org Code: 5 A620 \\ B\&R Code: EW3135040 \\ UC: 537 \\ Charge Code: E50071 / KPCN P97J00 \\ Total Pages: 52 s.3 $k$ mó $/ 4 / 44$
}

Key Words: Analysis, 305, Bridge Crane, Monorail

Abstract: The analyses in the appendix of this document evaluate the integrity of the existing bridge crane structure, as depicted on drawing H-3-34292, for a bridge crane and monorail assembly with a load rating of 2 tons. This bridge crane and monorail assembly is a modification of a 1 1/2 ton rated manipulator bridge crane which originally existed in the 305 building.

TRADEMARK DISCLAIMER. Reference herein to any specific collmercial product, process, or service by trade name, tradenark, manufacturer, or otherwise, does not necessarily constitute or imply its endorsement, recommendation, or favoring by the United States Government or any agency thereof or its contractors or subcontractors.

Printed in the United States of America. To obtain copies of this document, contact: WHC/BCS Document Control Services, P.O. Box 1970, Mailstop H6-08, Richland WA 99352, Phone (509) 372-2420; Fax (509) 376-4989.

It has been verjfied that the duplicated is not Copyrighted. KMB $1 / 6 / 96$
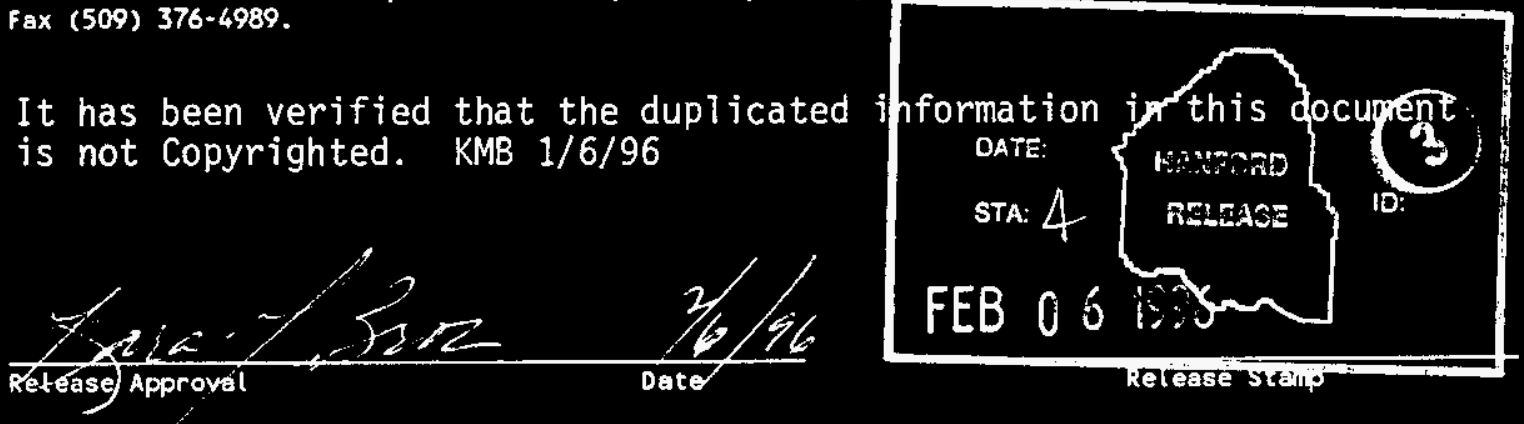

\section{Approved for Public Release}




\title{
305 BUILDING
}

2 TON BRIDGE CRANE AND MONORAIL ASSEMBLY ANALYSIS

\author{
December 1995
}

PREPARED BY: Wahd A M. D. Axup, Principal Engineer Analytical Services

REVIEWED BY: T. C. Mackey, Principal Engineer Analytical Services

APPROVED BY:

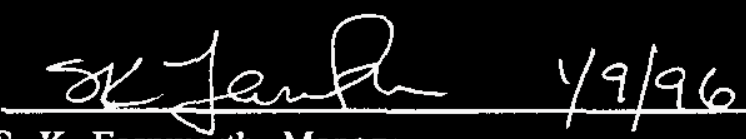

S. K. Farnworth, Manager

Analytical Services

ICF Kaiser Hanford Company

Hanford Operations and Engineering Contractor

for the

U. S. Department of Energy

Richland, Washington 


\section{CHECKLIST FOR INDEPENDENT REVIEW}

Document Reviewed 305 BUILDING 2 TON BRIDGE CRANE AND MONORAIL ASSEMBLY

Author M. D. Axup

Yex No N/A

D [ ] [ ] Problem completely defined.

め [ ] [ ] Necessary assumptions explicitly stated and supported.

[ ] [ ] $\bowtie$ Computer codes and data files documented.

$\bowtie$ [ ] [ ] Data used in calculations explicitly stated in document.

$\bigotimes \quad[$ [ ] Data checked for consistency with original source information as applicable.

D [ ] [ ] Mathematical derivations checked including dimensional consistency of results.

[ ] [ ] Models appropriate and used within range of validity or use outside range of established validity justified.

$\infty$ [ ] [ ] Hand calculations checked for errors.

[ ] [ ] $\bowtie$ Code run streams correct and consistent with analysis documentation.

[ ] [ ] \ Code output consistent with input and with results reported in analysis documentation.

\} \text { [ ] [ ] Acceptability limits on analytical results applicable and supported. Limits checked against } sources.

$\bowtie$ [ ] [ ] Safety margins consistent with good engineering practices.

D [ ] [ ] Conclusions consistent with analytical results and applicable limits.

$\infty$ [ ] [ ] Results and conclusions address all points required in the problem statement.

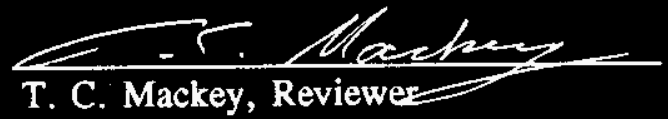

Date

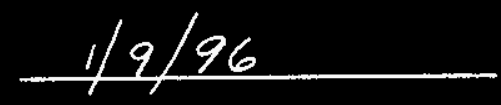




\section{CONTENTS}

1.0 INTRODUCTION $\ldots \ldots \ldots \ldots \ldots \ldots \ldots \ldots \ldots \ldots \ldots \ldots \ldots \ldots \ldots$

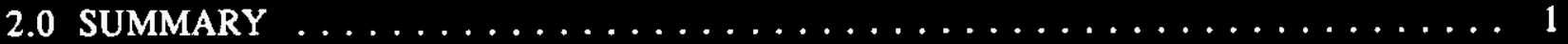

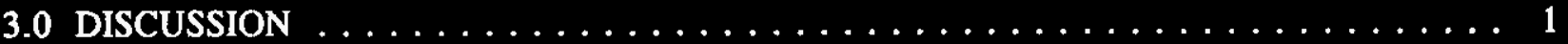

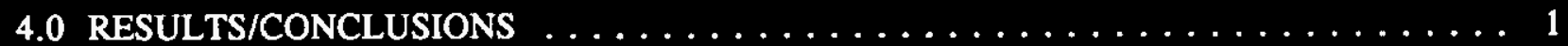

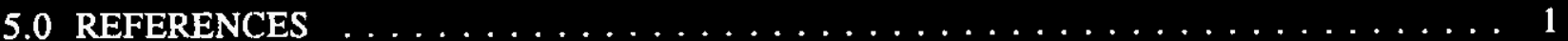

\section{APPENDICES}

Appendix A: 305 Building 2 Ton Bridge Crane and Monorail Structural Analysis . . . . . . . A-1 


\subsection{INTRODUCTION}

The analyses in the appendix of this document evaluate the structural integrity of the existing bridge crane structure, as depicted on drawing H-3-34292 (WHC 1977), for a bridge crane and monorail assembly with a load rating capacity of 2 tons. This bridge crane and monorail assembly is a modification of a $11 / 2$ ton rated manipulator bridge crane which originally existed in the 305 building. See Engineering Change Notice (ECN) \#628549 for a schematic depicture of modification referencing bridge crane load ratings and Certified Vendor Information (CVI) file number.

\subsection{SUMMARY}

The analyses in the appendix of this document show that the 305 building crane structure (WHC 1977) is adequate to support the 2 ton bridge crane and monorail assembly including the effects of impact (1.10 factor) as defined in the Manual of Steel Construction (AISC 1989). Loading for the bridge crane and monorail assembly may be any combination as long as the combined loading of either system is less than or equal to 2 tons. In addition, the analyses show that the crane structure is adequate for simultaneous loading of an existing $\mathbf{5}$ ton bridge crane, supported by the top crane rails, and loading of the new 2 ton bridge crane and monorail assembly, supported by the lower crane rails.

\subsection{DISCUSSION}

The modification of the original $11 / 2$ ton manipulator bridge crane is required to provide a mockup of a $\mathrm{K}$ basin monorail. The mockup is to be used to test and practice the handling of spent fuel in the $\mathrm{K}$ basins. The original manipulator bridge crane was supplied by The Bartholomew Co., Inc. and they were also chosen to supply the modification per WHC 1995a in accordance with WHC $1995 b$.

\subsection{RESULTS/CONCLUSIONS}

The structural analysis show that the existing design of the 305 building bridge crane structure is adequate to support the new 2 ton bridge crane and monorail assembly.

\subsection{REFERENCES}

AISC, 1989, Manual of Steel Construction, ninth Edition, American Institute of Steel Construction, Chicago, Illinois.

WHC, 1977, Structural Plan. Elevations \& Details, drawing H-3-34292, Westinghouse Hanford Company, Richland, Washington.

WHC, 1995a, Purchase Order, MDK-XDW-430047, Westinghouse Hanford Company, Richland, Washington.

WHC, 1995b, Specification For Modification of Manipulator Crane, WHC-S-047, Westinghouse Hanford Company, Richland, Washington. 
WHC-SD-SNF-DA-016, Rev. 0

Appendix A:

305 Building 2 Ton Bridge Crane and Monorail Assembly Structural Analysis

A-1 
WHC-SD-SNF-DA-01.6, Rev. 0

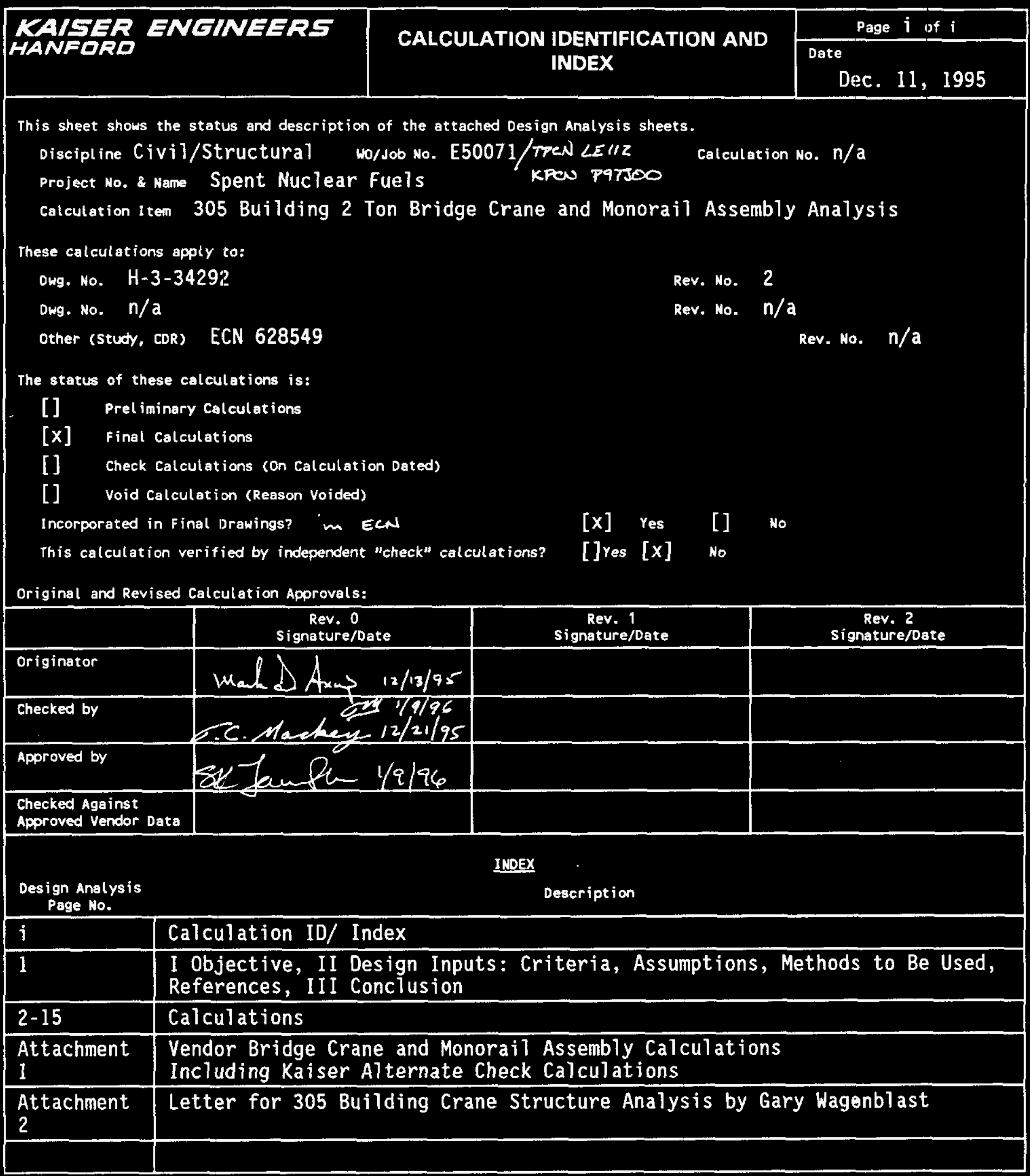


KAVERR ENEINEERS

HANFDRD

DESIGN ANALYSIS
client Westinghouse
subject Crane Rail Analysis for 2 Ton Monorail
and 2 Ton Bridge Crane
Location 305 B1dg.

WHC-SD-SNF-DA-016, Rev. 0

Calc. No. N/A

Revision 0

Page No. 1 of 15

wo/sob No. LEI12/KPCN P97J00

Date 12/05/95 By Mark Axup

checked $12 / 21 / 95$

Revised

sy G.C. Machey

By

\section{OBJECTIVE}

Provide a design analysis to qualify the existing crane structure in the 305 building, as depicted on drawing $\mathrm{H}-3-34292$, for a 2 ton crane rating supported on the lower crane rails. This rating is for the modified bridge crane and monorail assembly. Modifications were supplied by The Bartholomew Co., Inc. as per specification WHC-S-047 and purchase order MDK-XDW-430047.

\section{DESIGN INPUTS}

\section{A. CRITERIA}

1. Bridge crane and monorail assembly to be rated for a 2 ton capacity.

2. Steel shapes and plates are ASTM-A36.

3. Welding electrodes are E70XX.

4. Pombive Enfary Gussitcation Is SC. 3

B. ASSUMPTIONS

None

C. METHODS TO BE USED

1. Hand calculations.

\section{REFERENCES}

1. AISC Manual of Steel Construction, Allowable Stress Design, Ninth Edition.

2. AISC Manual of Steel Construction, Allowable Stress Design, Seventh Edition.

3. Design of Welded Structures, by Omer Blodgett.

4. Westinghouse Specification WHC-S-047, Specification For Modification of Manipulator Bridge Crane.

5. Westinghouse Purchase Order MDK-XDH-430047.

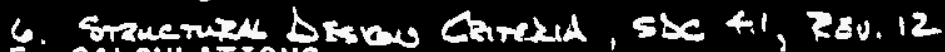

E. CALCULATIONS

Refer to following pages for design calculations.

\section{CONCLUSION}

The structural analysis show that the existing crane structure, as depicted on drawing $\mathrm{H}-3-34292$, is adequate to support the 2 ton bridge crane and monorail assembly. Loading for the bridge crane and monorail assembly may be any combination as long as the combined loading of either system is less than or equal to 2 tons. In addition, this calculation qualifies the existing crane structure for simultaneous loading of the 5 ton bridge crane, supported by the top crane rails, and loading of the new 2 ton bridge crane and monorail assembly, supported by the lower crane rails. 
KAISER ENGINEERS

HANFORD

DESIGN ANALYSIS

client Westinghouse

subject Crane Rail Analysis for 2 Ton Monorail and 2 Ton Bridge Crane

Location 305 B1 dg.
WHC-SD-SNF-DA-016, Rev. 0

Calc. No. $N / A$

Revision 0

Page No. 2 of 15

wo/sob Mo. LE112/KPCN P97J00

Date 12/05/95 By Mark Axup

checked $12 / 21 / 95$ By C. Machen

Revised

By

Load Condition 1: Monorail loaded at maximum with load centered on exist'g. bridge girder. Monorail is positioned at end of bridge girder.

Also, 2 ton hoist is unloaded, and positioned at end of bridge girder.

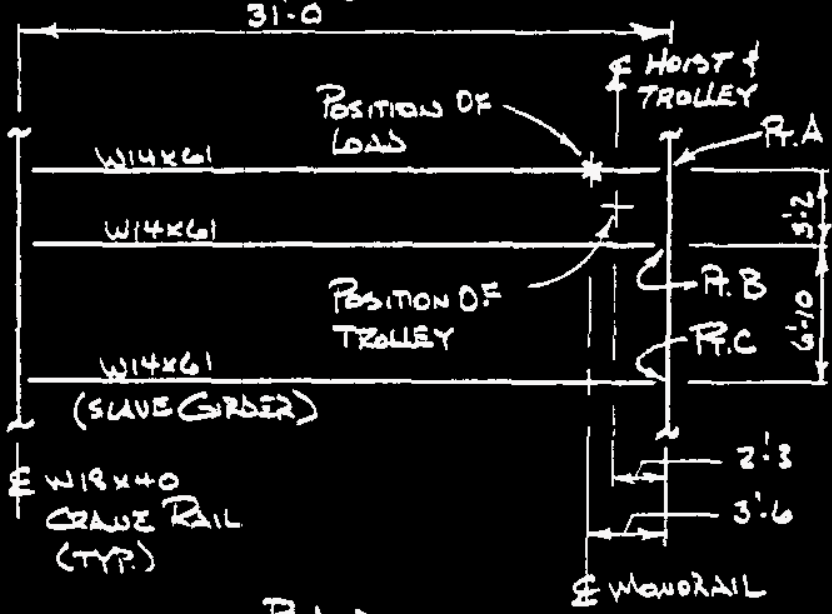

Plit

DESIGN LaADMO \& MATL. WEICHTS

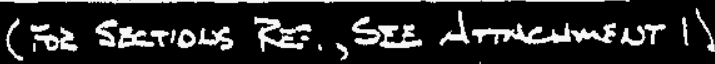

1. Liftes lods : $4000 \%$

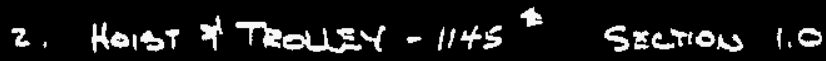

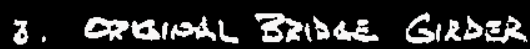

Ens TakK - $470^{*}$ Exeron 3.0

4. Movosall Hoist

4 Trouey - 41 * SEction 6.0

5. 1/2 Mowo2xil -

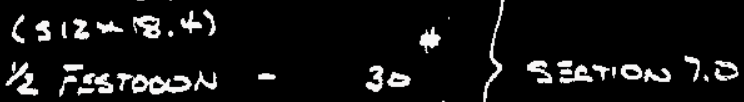

111

7 Co.s Bues - 288 *

8. Mavoust Eut Tack $-\frac{323^{*}}{1163^{*}}$

Combines

$1163 *$

(Alove 5 Intms)

Pasirioned@stots

9. Sung Girses En Truex - $300^{\#}$ Estimutas 10. Use $70 \% / k+, 702$ witkal + luises.

Calculate Wu. Whas lodls fox Pants A, B, ic

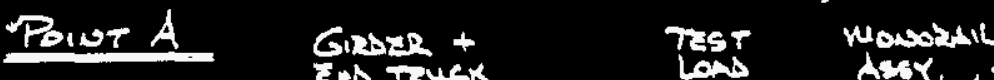

Ginser toux

Aser, 27.5 Hoist Telsy

$\max =[0.070(31.0)+0.478] 1 / 2+[4.0(1.25)+1.163]\left(\frac{27.5}{31.0}\right)+1.145(1 / 2)\left(\frac{28.75}{31.0}\right)=7.322^{k} U_{58}$ Tist Lon fimtar

$$
\Delta \mathbf{R}
$$

$\max _{1}=\left[[0.070(310)+0.470]^{1 / 2}+[4.0+1.163]\left(\frac{27.5}{31.0}\right)+1.145(1 / 2)\left(\frac{33.75}{31.0}\right)\right] 1.10=7.08^{k}$

Pont 3

$m_{A x}=\left[[0.070(31.0)+0.478]^{1 / 2}+1.145(1 / 2)\left(\frac{29.75}{31.0}\right)\right] 1.10=2.04^{k}$

Powr C

juin. $=\left[0.070(31.0) 1 / 2+0.300+[1.163-0.411]\left(\frac{27.5}{31.0}\right)\right] 1.10=2.26^{k}$ 
WHC-SD-SNF-DA-016, Rev. 0

KAISER ENGINEERS

HANFEFE

DESIGN ANALYSIS

ctient Westinghouse

subject Crane Rail Analysis for 2 Ton Monorail and 2 Ton Bridge Crane

Location 305 Bldg. calc. No. N/A

Revision 0

Page No. 3 of 15
wo/Job No. LE112/KPCN P97J00

Date $12 / 05 / 95$ By Mark Axup

checked $/ 2 / 21 / 95$

Revised
By -r. Manter

By

Load Condition 1: (Cont'd.)

Calculati C. S. OF WMERL LodAs

$$
\text { C.6. }=\frac{2.04(3.17)+2.26(10.0)}{7.32+2.04+2.26}-2.50
$$

By inspection, max. moment in crane rail will occur under the loaded W14x61 when the loads are positioned as shown below. Ref. AISC manual, p. 2-310, "General Rules for Simple Beams Carrying Moving Concentrated Loads"

Use moment distribution to calculate maximum bending moments in crane rail.

Conservatively, treat crane rail as a two span continuous beam.

Dismanes From $E$

Colume Past $d=[20.0-2.50]^{1 / 2}=8.75$

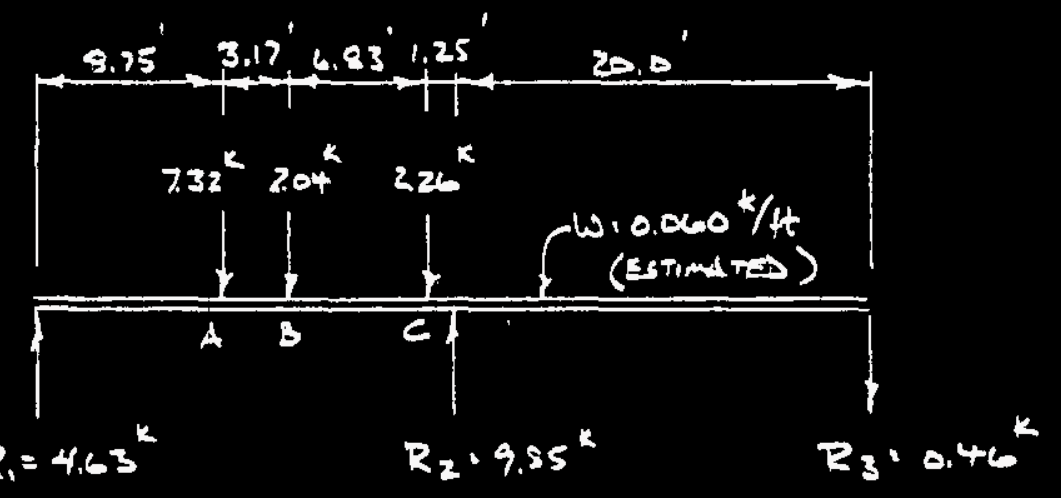

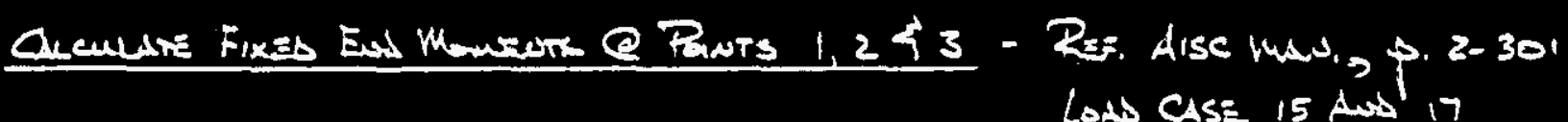

$F_{1}=-\left[\frac{0.060(20.0)^{2}}{12}+\frac{7.32(8.75)(11.25)^{2}}{20.0^{2}}+\frac{2.04(11.92)(8.08)^{2}}{20.0^{2}}+\frac{2.26(18.75)(1.25)^{2}}{20.0^{2}}\right]^{2}-26.40$

$F_{\text {EM }}=\frac{0.060(200)^{2}}{12}+\frac{7.32(11.25)(8.75)^{2}}{20.0^{2}}+\frac{2.0 \times(8.00)(11.92)^{2}}{20.0^{2}}+\frac{2.26(1.25)(18.75)^{2}}{20.0^{2}}=26.10^{1-k}$

$\frac{W_{2}}{\sigma_{M}}=\frac{-0.000(20.0)^{2}}{12}=-2.0^{1-k}$

$\mu_{3}=0.000(20.0)^{2}=+2.0^{1-k}$

Fim 
KAISER ENGINEERS

HANFERE

DESIGN ANALYSIS

client Westinghouse

subject Crane Rail Analys is for 2 Ton Monorail and 2 Ton Bridge Crane

Location 305 B1dg.
$A C-S 2-S N=-D A-016$, Rev, 0 Calc. No. $N / A$

flevision 0

Fage No. 4 of 15

w/Job No. LE112/KICN F97JCO

Date 12/05/95 By Mark Axup

checked $12 / 21 / 95$

Revised

\section{Load Condition 1: (Cont'd.)}

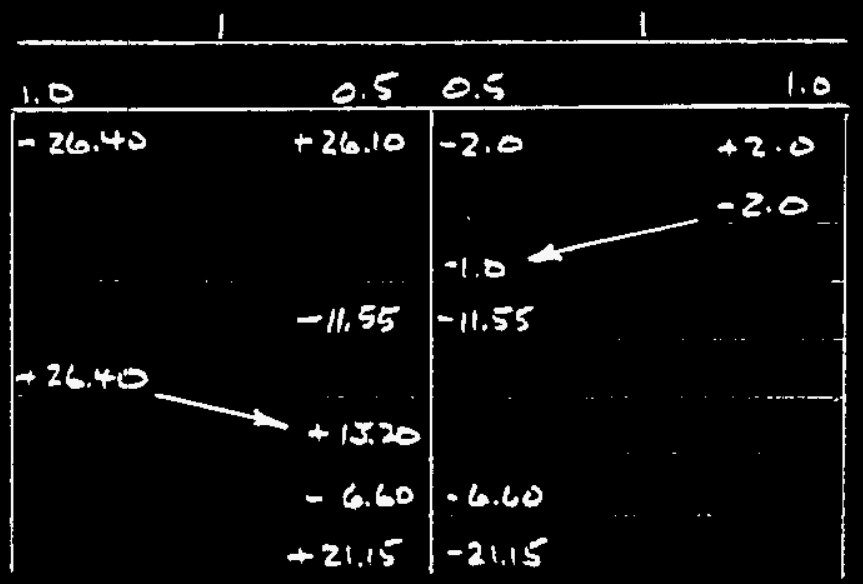

Reltive Stipknzss $k$ DistriBution Fatroz $=k / z k$ FEm

Muroek Jow 3, 3allues

CARRY OUEX

Buswes

Unear Jolnt 1, Bowhes

CAREY DoE

Bacues

Sumination $\Delta F$ Monsents

Fegs Boir Daczam,

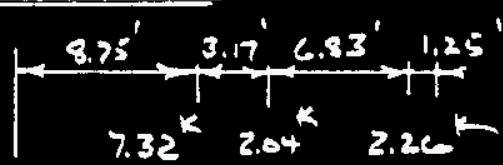

$\omega: 0.060^{k / 7 t}$

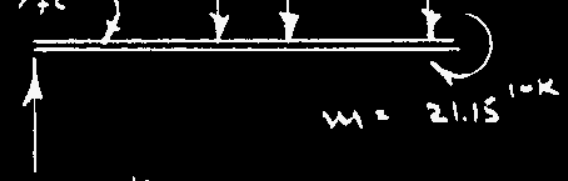

$R_{1}=4.63^{k}$

$$
\bar{K}_{1}=[7.32(11.25)+2.04(8.08)+2.26(1.25)
$$$$
\left.+0.060(20.0)^{2} / 2-21.15\right] 1 / 20.0: 4.63^{k}
$$

$\operatorname{lu}_{\text {max }}=4.63(8.75)-0.060(8.75)^{2 / 2}=38.22^{1-k}$

Fexs Bay DiaraAy 2

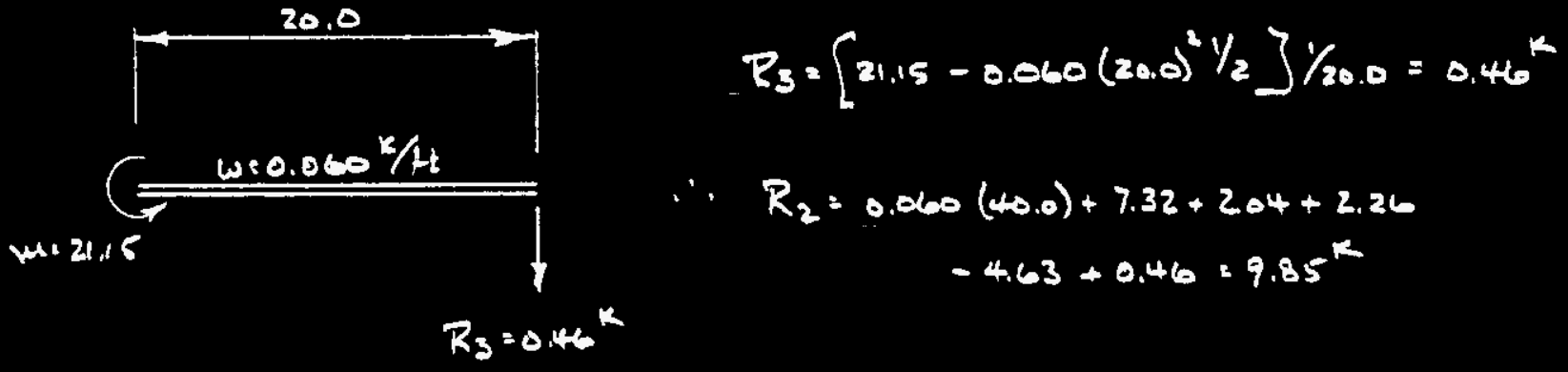

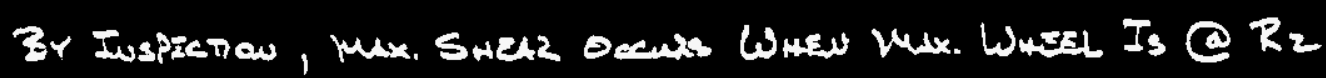

Cevezuativitr,

$$
V_{y}=0.060(20.0)+7.32+2.04\left(\frac{16.83}{20.0}\right)+2.26\left(\frac{100}{20.0}\right)=11.37^{K}
$$


KAISER ENGINEERS MANFORE

\section{DESIGN ANALYSIS}

ctient Westinghouse

subject Crane Rail Analysis for 2 Ton Monorail and 2 Ton Bridge Crane

Location 305 B1dg.
WHC-SD-SNF-DA-016, ReV, 0 Calc. No. N/A

Revision 0

Page No. 5 of 15

wo/Job Ho. LE112/KPCN P97J00

Date 12/05/95 By Mark Axup

Checked $12 / 21 / 95$

Revised

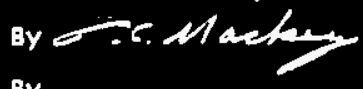

By

Load Condition 2: Monorail loaded at maximum with load centered on new slave girder. Monorail is positioned at end of bridge girder. Also, 2 ton hoist is unloaded, and positioned at end of bridge girder.

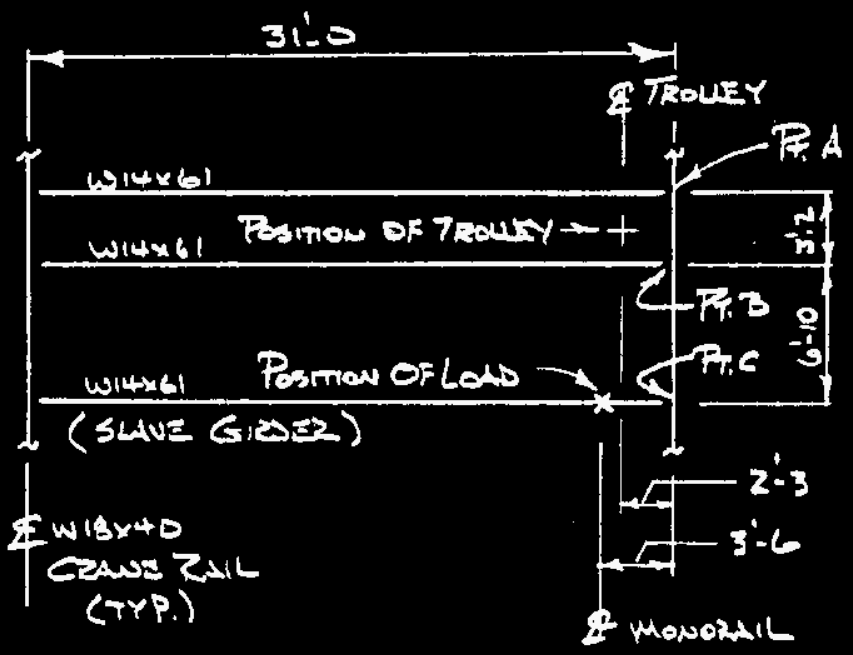

\section{PAN}

Note: Howezall \& Teousy Axs

Posinows $\mathbb{C}$ Srops

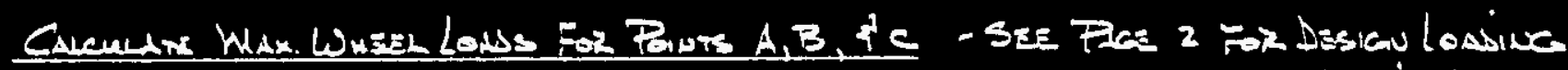
Poivt A cisst - mavenil Asery

$m_{x x}=\left[[0.070(31.0)+0.4 \times 6] 1 / 2+(1.163-0.411)\left(\frac{27.5}{31.0}\right)+\right.$

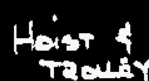

F Mutik. LERors

Tacus

Pour 3

$$
\text { luax. }=\left[[0.070(31.0)+0.4 \times 9] / 2+1.145(1 / 2)\left(\frac{38.75}{31.0}\right)\right] 1.10=2.04^{*}
$$

Ponte

$m_{\text {ax. }}=0.070(31.0)^{1 / 2}+0.300+[4.0(1.25)+1.163]\left(\frac{27.5}{31.0}\right)=6.85^{k}+$ U1.5

\section{$O R$}

$\operatorname{lundx}=\left[0.070(31.0)^{1 / 2}+0.300+[4.0-1.163]\left(\frac{27.5}{31.0}\right)\right] 1.10=6.50^{k}$ 


\section{KAISER ENEINEERS}

HANFRRE

\section{DESIGN ANALYSIS}

WHC-SD-SNF-DA-016, Rev. 0

Calc. No. N/A

Revision 0

Page No. 6 of 15

w/Job No. LE112/K.PCN P97J00

Date 12/05/95 By Mark Axup

Checked $12 / 21 / 95$

Revised
By C. Machese

\section{Load Condition 2: (Cont'd.)}

Cuculans C.6. OF Wugal Lads:

$$
C .6 .=\frac{2.04(3.17)+6.85(10.0)}{2.17+2.04+6.85}=6.43^{\prime}
$$

SLuve Labed

By inspection, max. moment in crane rail will occur under the loaded W14x61 when the loads are positioned as shown below. Ref. AISC manual, p. 2-310, "General Rules for Simple Beams Carrying Moving Concentrated Loads"

Use moment distribution to calculate maximum bending moments in crane rail. Conservatively, treat crane rail as a two span continuous beam.

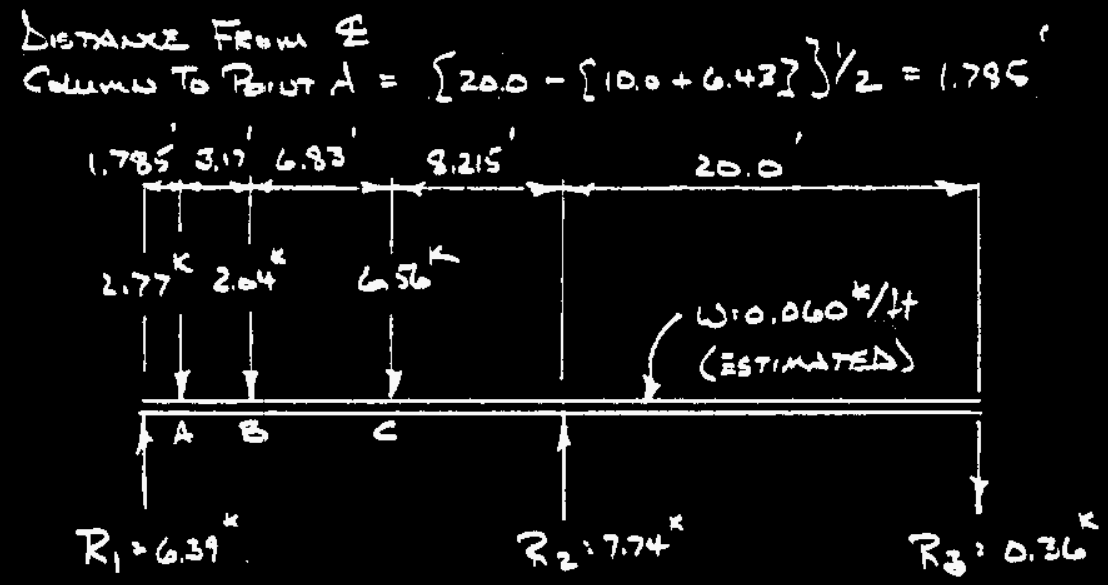

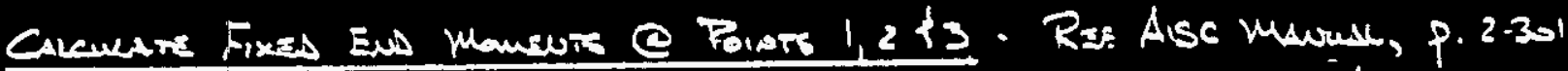
Lon Cases $15^{-}+17$.

$W_{1}=-\left[\frac{0.000(20.0)^{2}}{12}-\frac{2.77(1.705)(18.215)^{2}}{20.0^{2}}+\frac{2.04(4.955)(15.045)^{2}}{20.0^{2}}+\frac{6.56(11.785)(3.215)^{2}}{20.0^{2}}\right]^{2}=24.86$ ${ }_{F E \mu_{2}}=\frac{0.00(20.0)^{2}}{12}+\frac{2.77(18.215)(1.785)^{2}}{20.0^{2}}+\frac{2.04(15.045)(4.955)^{2}}{20.0^{2}}+\frac{6.56(8.215)(11.785)^{2}}{20.00^{2}}=23.00^{1-k}$ $M L_{2}=\frac{-0.000(200)^{2}}{12}+-2.0^{1-k}$

Fam

$m_{3}=\frac{0.060(20.0)^{2}}{12}=+2.0^{1-k}$

isin 
WHC-SD-SNF-DA-016, Rev. 0

\section{KAISER ENGINEERS} HANFERE

DESIGN ANALYSIS

$\mathrm{client}$ Westinghouse

subject Crane Rail Analys is for 2 Ton Monorail and 2 Ton Bridge Crane

Location 305 Bldg. calc. No. $N / A$

Revision 0

Page No. 7 of 15

wo/Job No. LE112/KPCN P97J00

Date 12/05/95 By Mark Axup

checked $12 / 21 / 95$

Revised

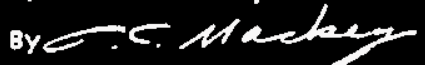

By

Load Condition 2: (Cont'd.)

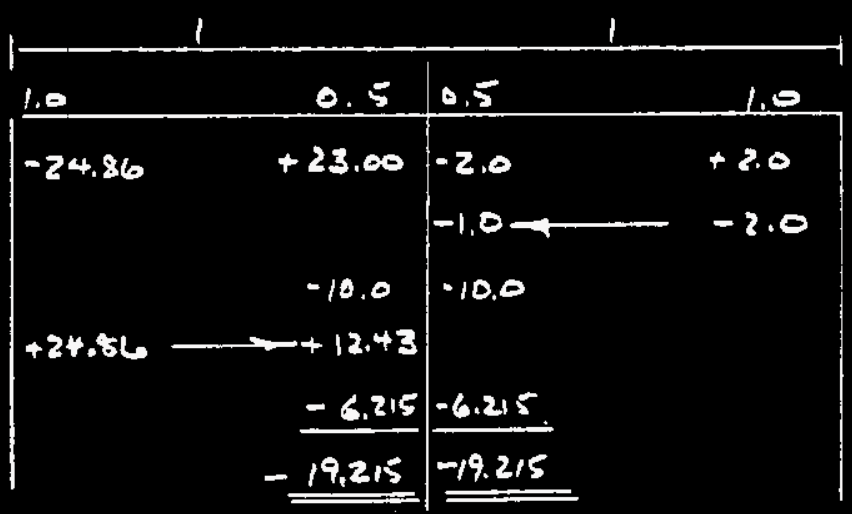

REL.Stw STIF. $k$ Distrib, Fietoz $=k / \Sigma k$ $=E m$

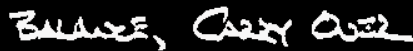

Banver

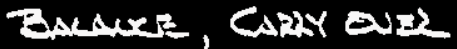

Bulves

Summation of Momserts

FrEE Bady DiaG2Am 1

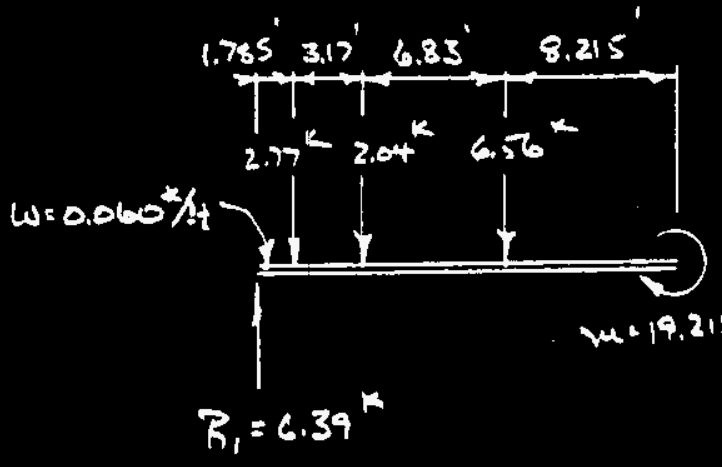

$$
\begin{aligned}
R_{L}= & {\left[0.000(20.0)^{2} / 2+2.77(18.215)+2.04(15.045)\right.} \\
& +6.56(8.215)-19.2 .5]^{4} / 20.0=6.39^{4}
\end{aligned}
$$

Frze Body Diagzam 2

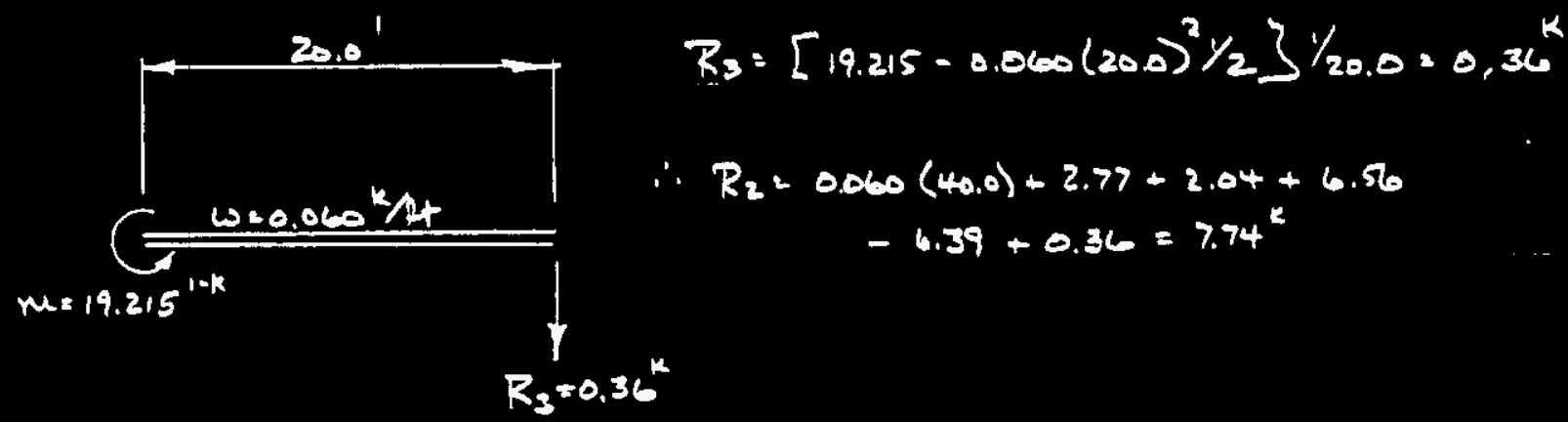

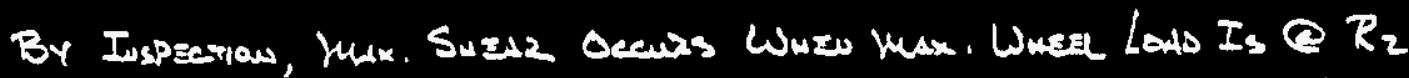

Conseluanuety, $V_{y}=0.060(20.0)+6.56+2.04\left(\frac{13.17}{20.0}\right)+2.77\left(\frac{10.0}{20.0}\right)=10.49^{k}$ 
WHC-SD-SNF-DA-016, ReV, 0

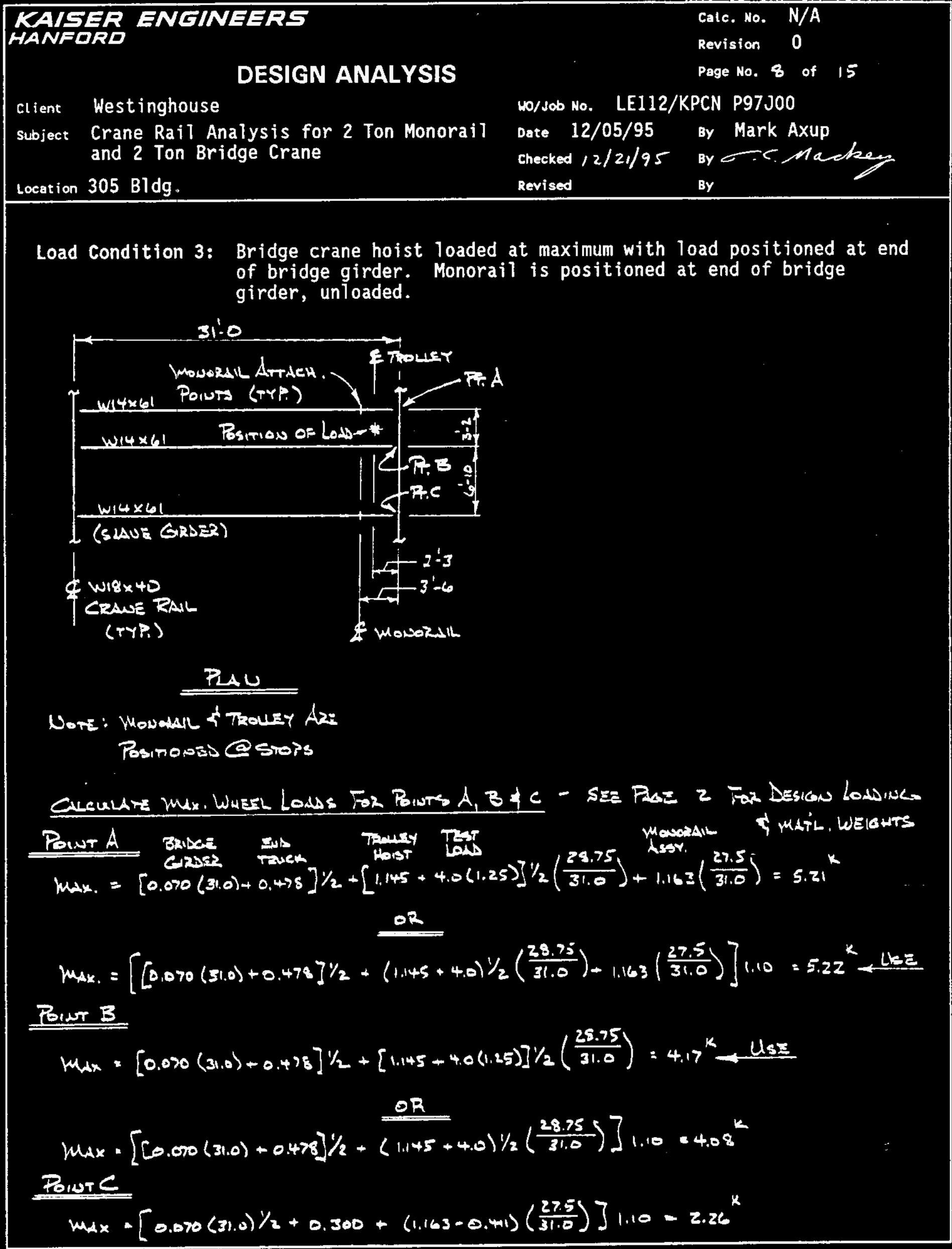


WHC-SD-SNF-DA-016, Rev. 0

KAISER ENGINEERS

HANFGRD

DESIGN ANALYSIS

client Westinghouse

subject Crane Rail Analys is for 2 Ton Monorail and 2 Ton Bridge Crane

Location 305 B1 dg. calc. No. $N / A$

Revision 0

Page No. 9 of 15

wo/sob No. LE112/KPCN P97J00

Date $12 / 05 / 95$

checked $/ 2 / 21 / 95$

Revised

By Mark Axup

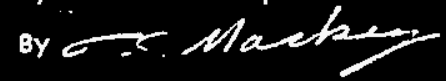

By

Load Condition 3: (Cont'd.)

Caculare C.G. of Poin Lows A,B, \&C

$$
\text { C.G. }=\frac{4.17(3.17)+2.26(10.0)}{5.22+4.17+2.26}=3.07
$$

By inspection, max. moment in crane rail will occur under the loaded W14x61, at point B, when the loads are positioned as shown below. Ref. AISC manual, p. 2-310, "General Rules for Simple Beams Carrying Moving Concentrated Loads"

Use moment distribution to calculate maximum bending moments in crane rail. Conservatively, treat crane rail as a two span continuous beam.

Domaves r̈zom $\mathscr{E}$ coums to Fant $4=[20.0 \cdot[3.17+3.07\}] \frac{7}{2}=6.88$

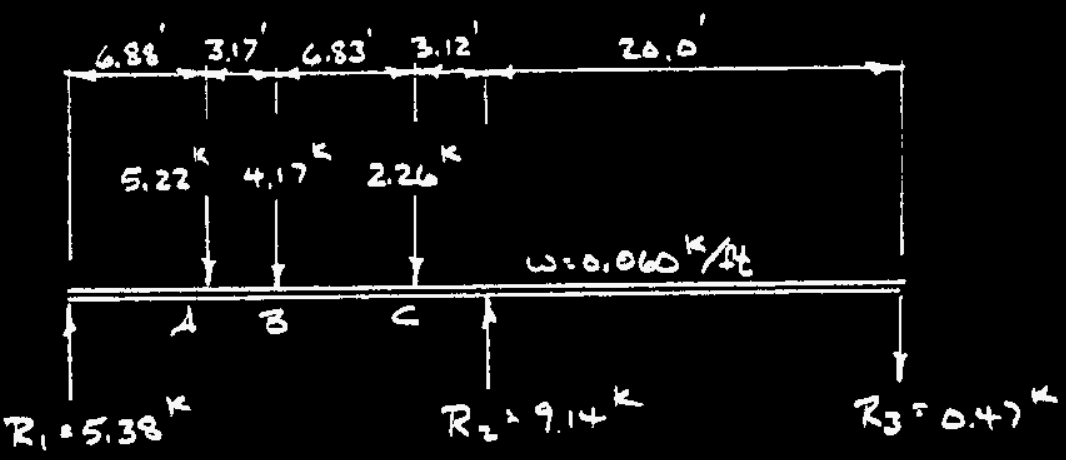

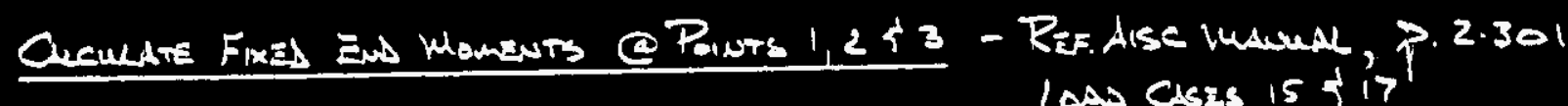

$m_{1}=-\left[\frac{0.060(20.0)^{2}}{12}+\frac{5.22(6.85)(13.12)^{2}}{20.0^{2}}+\frac{4.17(10.05)(9.95)^{2}}{20.0^{2}}+\frac{2.26(16.83)(3.12)^{2}}{20.0^{2}}\right]=-28.76^{1-k}$

$m_{2} L=\frac{0.06(20.0)^{2}}{12}+\frac{5.22(13.12)(6.98)^{2}}{20.0^{2}}+\frac{4.17(9.95)(10.05)^{2}}{20.0^{2}}+\frac{2.26(3.12)(16.85)^{2}}{20.0^{2}}+25.60^{10 k}$

$M_{2 R}=\frac{0.00(20.0)^{2}}{12}=-2.0^{1-K}$

PEm

$F_{3}=\frac{0.060(20.0)^{2}}{12}=+2.0^{1 *}$ 
KAISER ENGINEERS

MANFERD

DESIGN ANALYSIS

client Westinghouse

subject Crane Rail Analysis for 2 Ton Monorail and 2 Ton Bridge Crane

Location 305 Bldg.
WHC-SD-SNF-DA-016, Rev. 0 Calc. No. N/A

Revision 0

Page No. 10 of 15

w/sob No. LE112/KPCN P97J00

Date 12/05/95 By Mark Axup

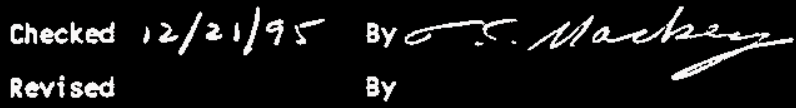

Load Condition 3: (Cont'd.)

\begin{tabular}{|c|c|c|c|}
\hline 1.0 & 0.5 & 0.5 & 1.0 \\
\hline \multirow[t]{3}{*}{-28.76} & +25.60 & -2.0 & +2.0 \\
\hline & & -1.0 & -2.0 \\
\hline & -11.30 & -11.30 & \\
\hline \multirow[t]{3}{*}{+24.76} & -14.38 & & \\
\hline & .7 .19 & $=7.19$ & \\
\hline & +21.49 & -21.49 & \\
\hline
\end{tabular}

RaL. SPAw STIFF. $K$

Distrits. FASTOL $=k / \Sigma k$

FEM

Baudes, Gazr Ousz

Ballawes

Baldues, cardy ouse

Batuce

Summdtion of Mowsuts

Fros Basy Ditanim 1

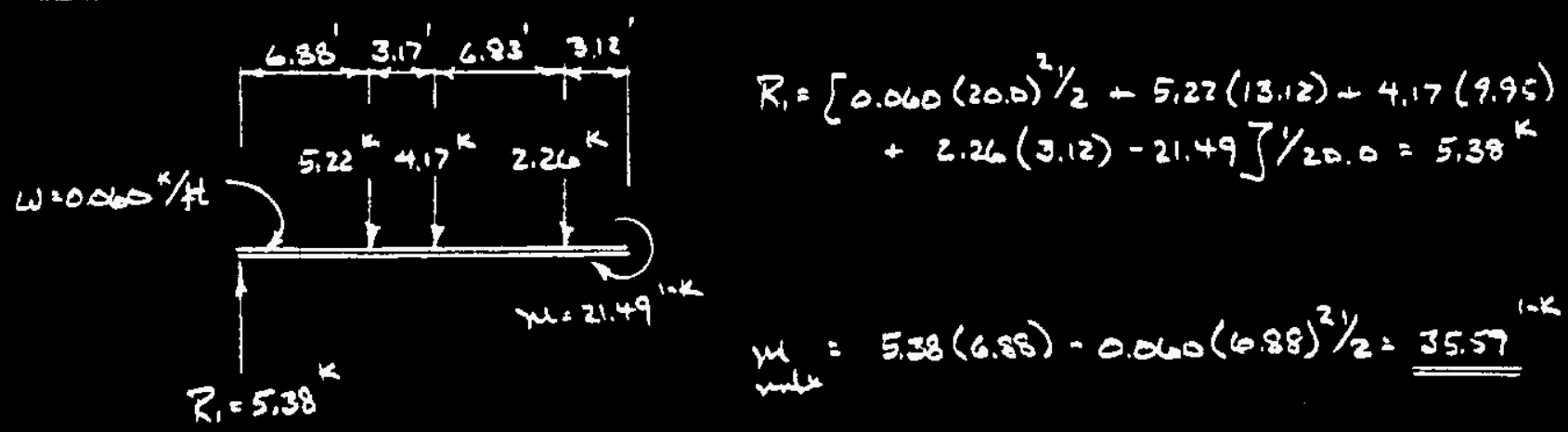

Fase Bor Dicram 2

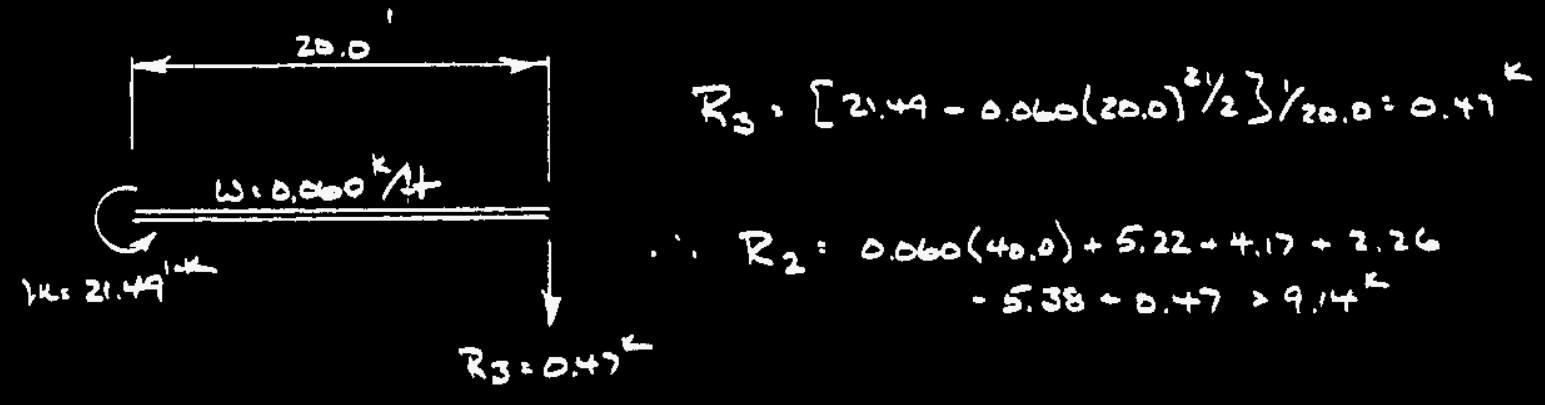

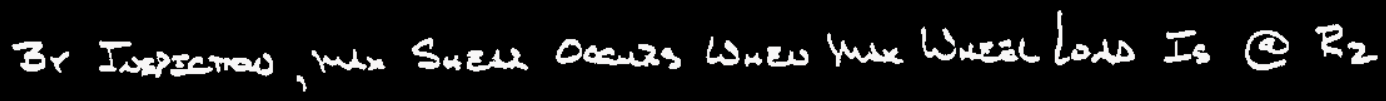

Conasevarivity, $V_{y}=0.060(20.0)+5.22+4.17\left(\frac{16.83}{20.0}\right)+2.26\left(\frac{10.0}{20.0}\right)=11.06^{k}$ 
WHC-SD-SNF-DA-016, Rev. 0

\section{KAISER ENEINEERS \\ HANFGRD}

\section{DESIGN ANALYSIS}

client Westinghouse

subject Crane Rail Analysis for 2 Ton Monorail

and 2 Ton Bridge Crane

Location $305 \mathrm{Bldg}$.
Calc. No. N/A

Revision 0

Page Ho. 11 of is

wo/Job No. LE112/KPCN P97J00

Date $1 / 09 / 96$

checked $1 / 9 / 96$

Revised

Loading Conclusion: Load condition 1, which has all the load on the monorail assy., controls as the worst load case for analyzing the crane rail and also the column attachment. Load condition 3, which has all the load on the bridge crane, is less than load condtion 1. Therefore, any combination of loading between the monorail and the bridge crane will be less critical than when the monorail is fully loaded.

Lateral loading: Per section A4.3 of the AISC manual, p. 5-29, the lateral force for analysis is $20 \%$ of the sum of the lifted load and crane trolley only. Load conditions 1 and 2 have the monorail loaded. The monorail is to be used for a $K$-bas in mockup where the lifted load will only be moved parallel to the crane rails. Furthermore, the motors for the monorail, both the end trucks and the monorail hoist, are at very low speed ratings of $16 \mathrm{fpm}$ and also are equipped with soft starts and stops. Therefore, the monorail load conditions will not impose a lateral load to the crane rails.

Use load condition 3 to calculate the lateral bending moment in the crane rails.

\section{Calculate Maximum Lateral Wheel Loads for Points A \& B}

Since the crane rail is rigidly restrained at top and bottom flanges at it's connection to the building columns, consider beam as being fixed at both ends for weak axis bending. Conservatively, calculate maximum bending moment by applying entire load at center of span.

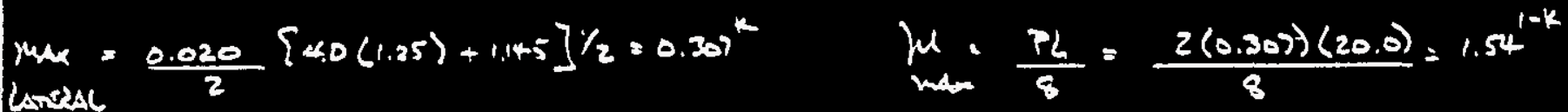

Compare Maximum Lateral Wheel Loads due to Impact to Lateral Loading due to Seismic

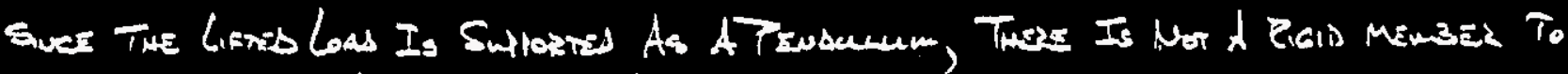

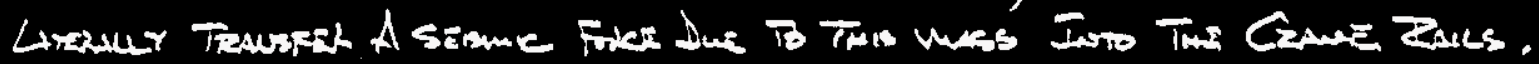

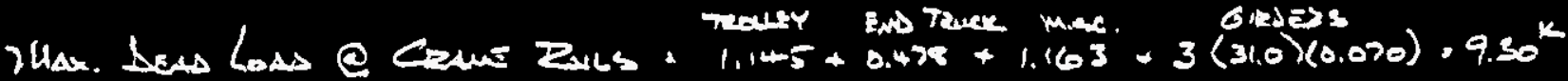

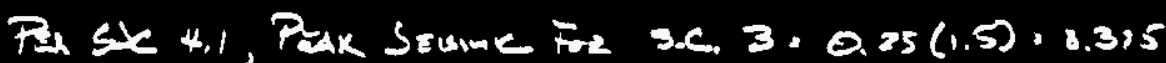

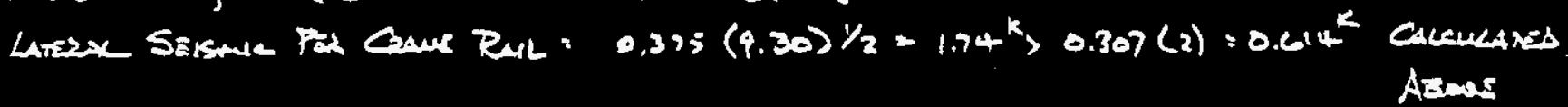

$\therefore$ Munt Cuser Sisme 
KAISER ENGINEERS HANFDRO

DESIGN ANALYSIS

Revision 0

Page No. 12 of 15

client Westinghouse

wo/sob No. LE112/KPCN P97J00

subject Crane Rail Analysis for 2 Ton Monorail and 2 Ton Bridge Crane

Location 305 Bldg.

Date $12 / 05 / 95$

checked 1/9/76

Revised
By Mark Axup

By C. Whala

By

\section{Crane Rail Stress Analysis:}

Desias lodswa

(From Pravions Parse 2 Trionam 11)

$M_{x}=39,22^{1-k}$ ?

$V_{y}=11.37^{k}\{$ SeE lods Cosdinon 1

$\left.m_{x}=35.54^{1-k}\right)$

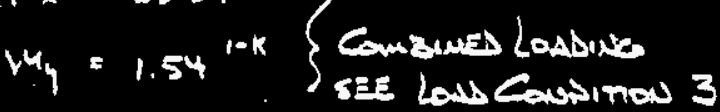

$/ r_{t}=\frac{20.0(12)}{1.52}=157.89>\sqrt{\frac{510 \times 10^{3} \mathrm{Cb}}{7 y}}=119.02$

$d=17.90 \mathrm{in}$ $D R$ $F_{b_{x}}=\frac{170 \times 10^{3} C_{b}}{\left(l / r_{t}\right)^{2}}=\frac{170 \times 10^{3}(1.0)}{(157.89)^{2}}=6.82^{\mathrm{kgl}} \quad$ Fandrod F1.7, Alsc unw, $F_{b_{x}}=\frac{170 \times 10^{3} C_{b}}{\left(l / r_{t}\right)^{2}}=\frac{170 \times 10^{3}(1.0)}{(157.89)^{2}}=6.82^{\mathrm{kgl}} \quad$ Fandrod F1.7, Alsc unw,

wisx40 Stertion Paptrtics.

$d=11.80 \mathrm{in}^{2}$

$t_{w}=0.315$ in

Lf $=6.015$ is

$t_{f}=0.525 \mathrm{in}$

$r_{t}=1,52$ is

$d / A_{f}=5.67$
$I_{x}=612 \mathrm{in}^{4}$

Sx: $68 .+$ in $^{3}$

$I_{y}=19.1 \mathrm{in}$

$L_{c}=6.30 \mathrm{tt}$

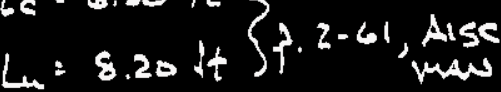

$S_{y}=\frac{5 y / 2}{b / / 2}=\frac{19.1}{6015}$

$=3.18 \mathrm{in}^{3}$

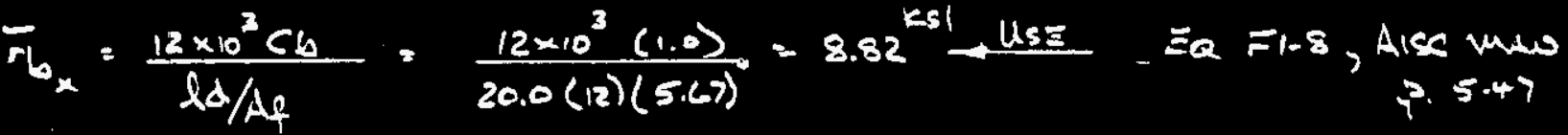
$F_{b_{y}}=0.75 F_{y}=0.75(36.0)=27.0^{\mathrm{ksl}}$

Ea F-2-1, Aise man

$f_{b x} \cdot \frac{38.22(12)}{68.4}=6.71^{k 81}<8.82^{k 91}$ ok

$f_{q}=\frac{11.37}{(19.90)(0.315)}: 2.02^{k+1}<F_{v}=0.4 F_{y}=14.4^{k=1} \mathrm{Kk}$

Cuesc Compines Loubine

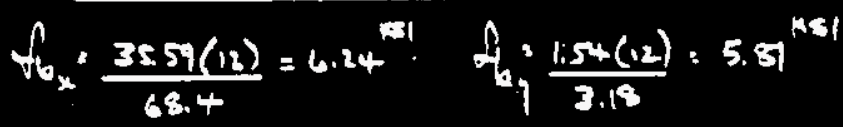

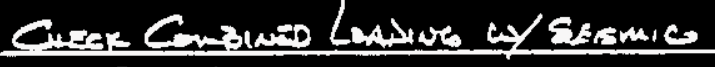

I.R.F $\frac{6.24}{8.42}-\frac{5.81}{27.0}=0.92<1.0$.k $I . R=\frac{6.24}{0.82}+\frac{5.81\left(\frac{1.74}{0.614}\right)}{27.0}=1.32<1.33^{\text {OK }}$ 


\section{KAIGER ENGINEERS}

HANFERE

DESIGN ANALYSIS

client Westinghouse

subject Crane Rail Analys is for 2 Ton Monorail and 2 Ton Bridge Crane

Location 305 B1dg.
WHC-SD-SNF-DA-016, Rev, 0 Calc. No. $N / A$

Revision 0

Page No. 13 of 15

wo/sob No. LE112/KPCN P97J00

Date 12/05/95 By Mark Axup

checked $12 / 21 / 95$

Revised

By

By

\section{Check Attachment of Crane Rail to Column:}

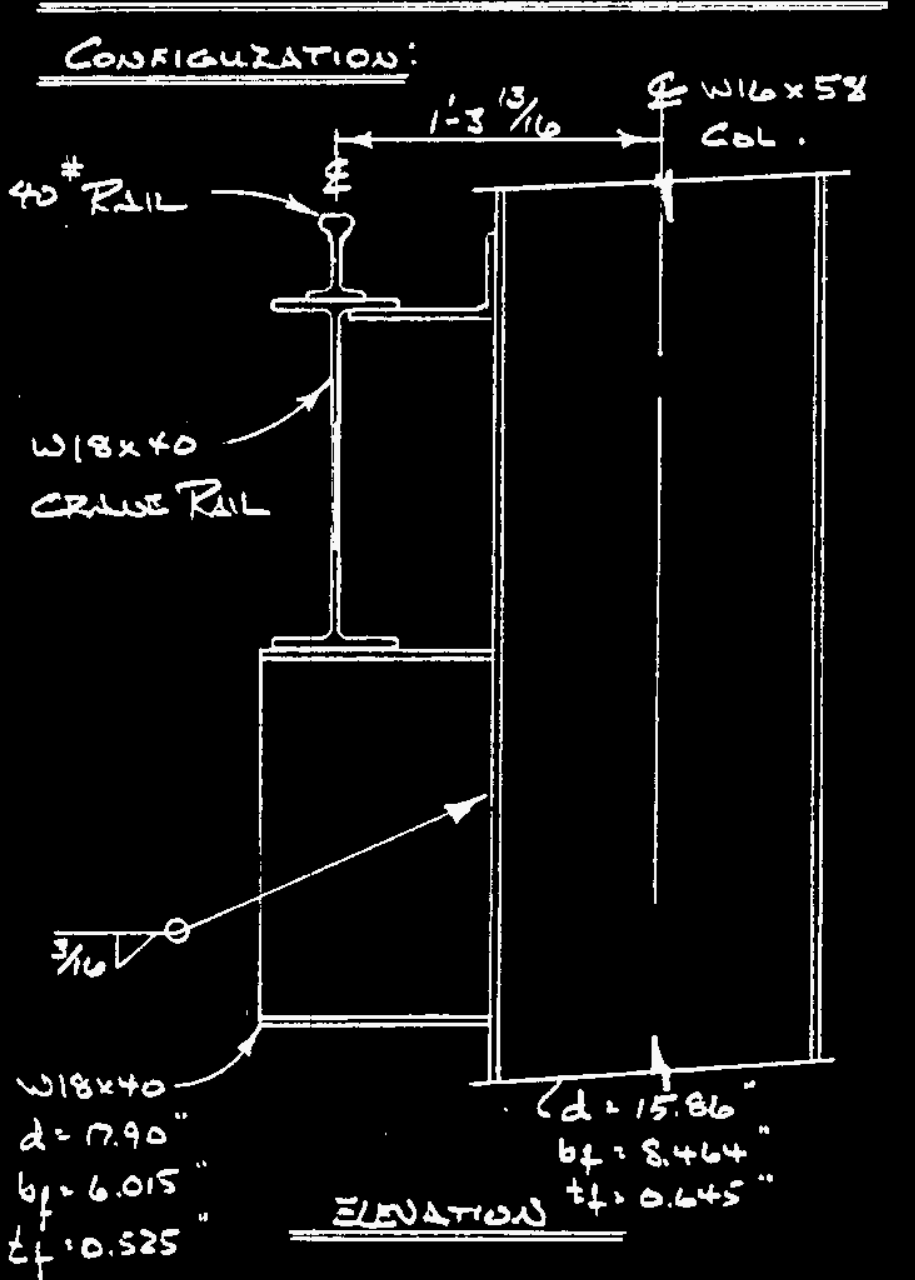

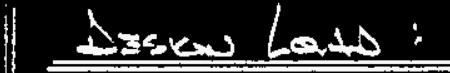
$V_{y}=11.37^{k}$ SEs Las Consimou 1

Consyadtively, Eueahire komat @ E of Coums.

$w=11.37(1.32)+15.0^{1-k}$

viste

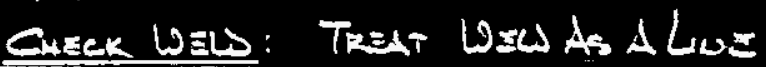
Rar, Basat", Dision of

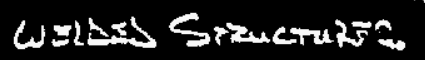

Qub Paparias:

$A=2 \times 18.36$ in

s. $26 d+\frac{d^{2}}{3}$

$$
=2(6.0)(18.0)+\frac{18.0^{2}}{3} \cdot 324.0: i^{2}
$$

\section{wrib Sress:}

$f=\left[\left(\frac{11.37}{36.0}\right)^{2}+\left(\frac{15.0(12)}{324.0}\right)^{2}\right]^{1 / 2}=0.639 \%$

$\omega_{\text {Tadi }}=\frac{0.639}{0.3(70.0) 0.707}=0.04 " k<3 / 10 "$ ok 
WHC-SD-SNF-DA-016, Rev, 0

\section{KAISER ENGINEERS \\ HANFERE}

DESIGN ANALYSIS

ctient Westinghouse

subject Crane Rail Analysis for 2 Ton Monorail and 2 Ton Bridge Crane

Location 305 B $1 \mathrm{dg}$.
Calc. No. N/A

Revision $\mathbf{O}$

Page No. 14 of 15

w/Job No. LE112/KPCN P97J00

Date 12/05/95 By Mark Axup checked $12 / 21 / 95$

Revised

By

Check Attachment of Crane Rail to Column: (Cont'd.)

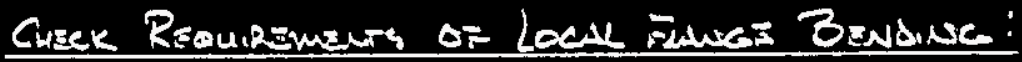

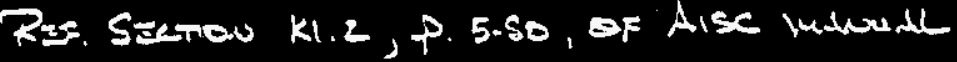

$$
\begin{aligned}
& P_{B f}=\left[\frac{15.0(12)}{17.90-0.525}\right] 5 / 3=17.27^{K}
\end{aligned}
$$

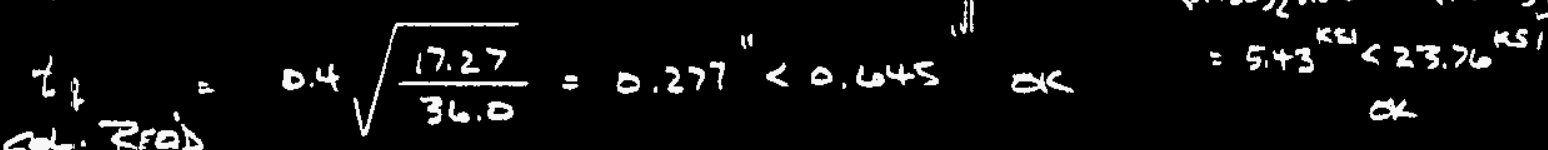

Curek locAl wes Buckine:

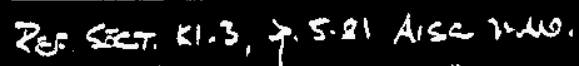
$k: 1.375 ", N-t_{f}: 0.525 ", 20.0 .430$

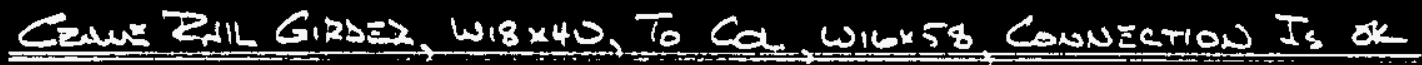

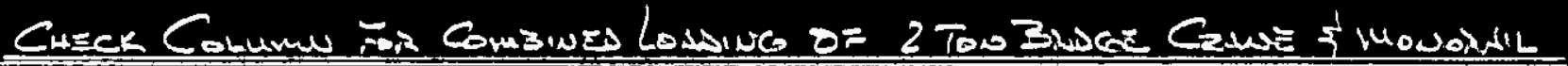

\section{Ans 5 Ton Benas Cane}

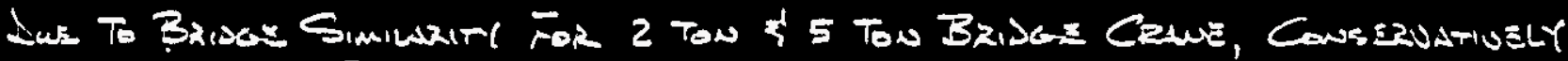

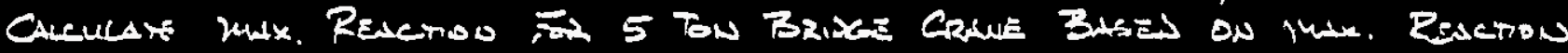

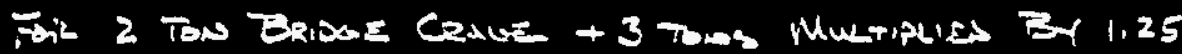

$$
V_{Y}=(11.37+6.0) 1.25,21.7^{K}
$$

lotas $\tan$

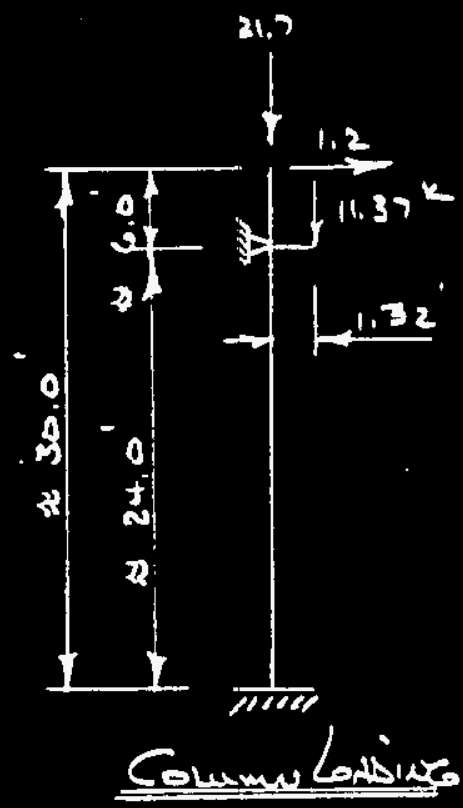

$V_{x}=0.20(10.0+2.0) \cdot 1.2^{k}$ 10 Tos 2

Esmmanes Wevatr of 5 Tos BRises Trablex
Nons: $k=1.0$ 


\section{DESIGN ANALYSIS}

ctient Westinghouse

subjece Crane Rail Analys is for 2 Ton Monorail and 2 Ton Bridge Crane
Revision $\mathbf{O}$

Page No. 15 of 15

wo/sob No. LEI12/KPCN P97J00

Date 12/05/95 By Mark Axup

cheeked $1 / 9 / 96$

By C.C. Machery

Revised

By

Check Column For Combined Loading: (Cont'd.)

W16.54 PROPARES

$$
\begin{aligned}
& A=17.04: 2 \\
& \alpha / A_{t}=2.91 \\
& S_{x}=9.4 .1 \mathrm{in} \\
& T_{x}=6.62 \text { in } \\
& \Gamma_{y}=1.88 \mathrm{in} \\
& L=24.5 t \\
& \text { uwerand } \\
& f_{6 .}=\frac{22.2(12)}{94.1}=2.83^{k 1} \\
& F_{6 x} \cdot \frac{12 \times 10^{3} c L}{\lambda d / A q}=\frac{12 \times 10^{3}(1.0)}{24.0(12)(2.91)}=14.32^{\mathrm{ksl}}
\end{aligned}
$$

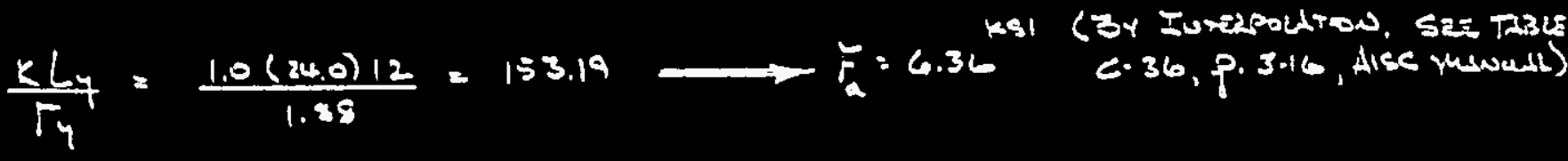

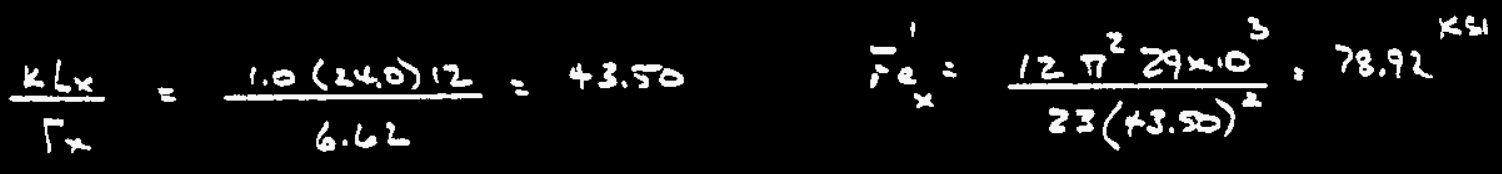$$
f_{a}=\frac{33.07}{17.04}=1.94^{k 41} \frac{f_{a}}{F_{a}}=\frac{1.94}{6.36}=0.31>0.15
$$

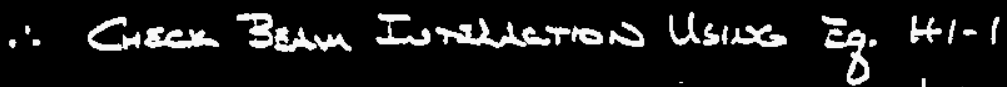

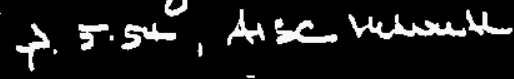

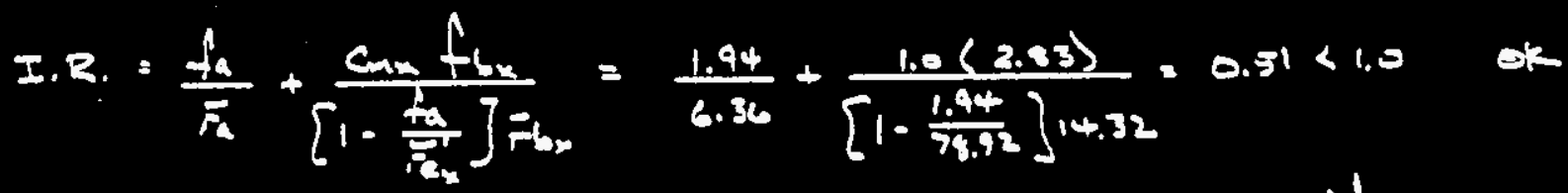

\section{Conclusion:}

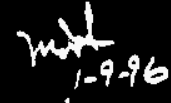

Extend 7 is conention

This column analys is of the building crane structure meptfies thewatidty of the letter fron Gary Wagenblast, dated 8/23/83 (see attachnent 2). In the 1etter, Mr. Wagenblast states that the structure was analyzed for a 10 ton bridge crane for the top rails and a manipulator bridge crane (of unknown rated capacity) for the lower rails. The letter only identifies crane rajl and beam to column deficiencies that would need to be addressed for a much higher load combination than is required for this modification and is addressed in this calculation. Since the crane rail and its connections are qualified in this calculation, no further building analysis is required. 
Attachment 1:

Vendor Bridge Crane And Monorail Assembly Calculations Including Kaiser Alternate Check Calculations

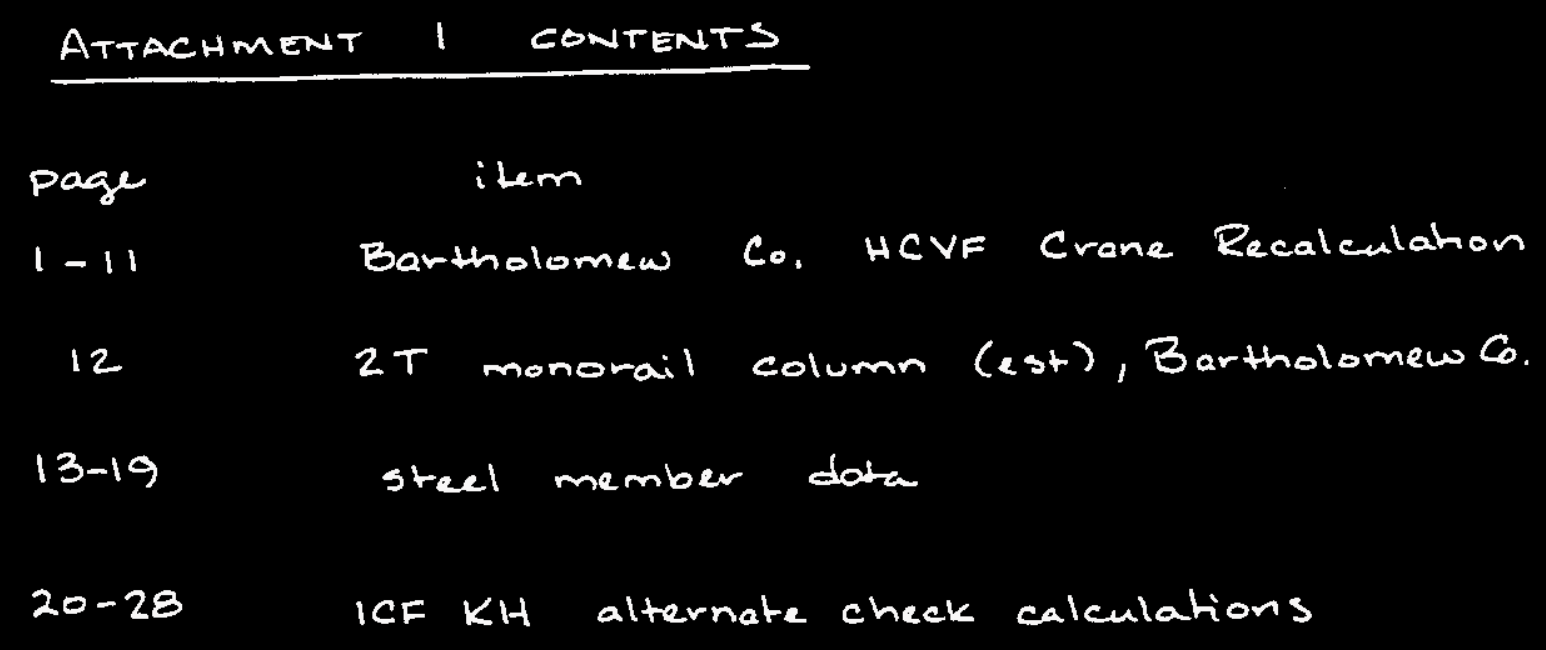


WHC-SD-SNF-DA-016, Rev. 0

THE BARTHOLOMEW COMPANY, INC.

91 NEW YORK AVENUE WESTEURY. N.Y. 11590 Phone (516) 333-0100. Fax (516) 333-0301

REVSION D DATES $=$ customin Jö nUMBer $\geqslant 362$ PREPAREO BY 4602

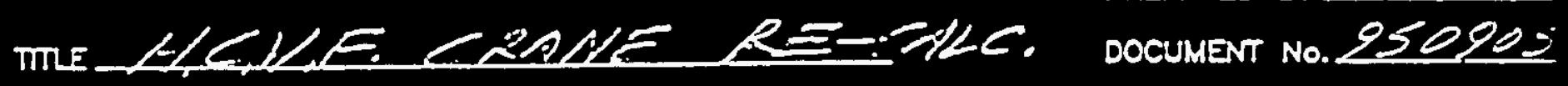

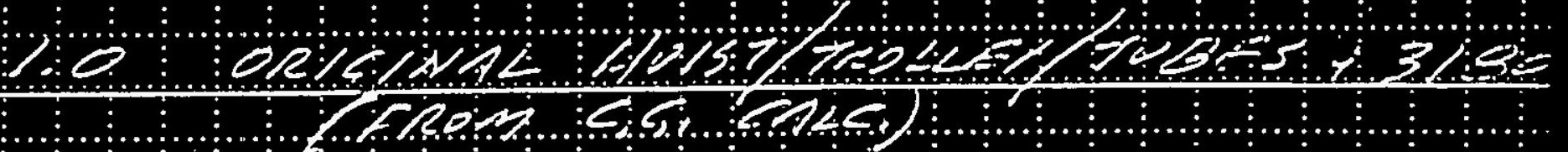

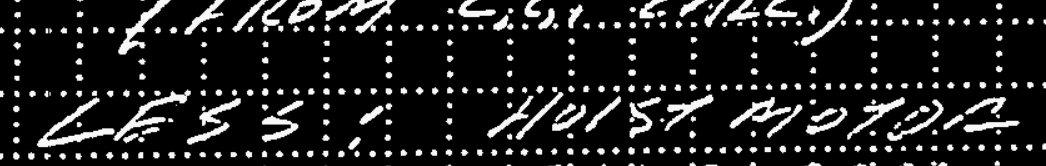

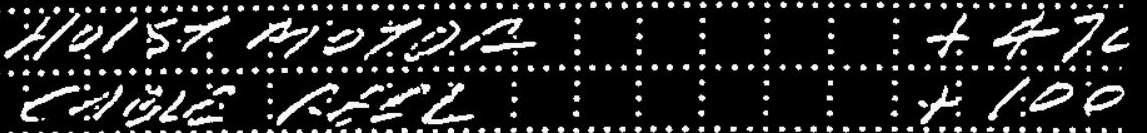

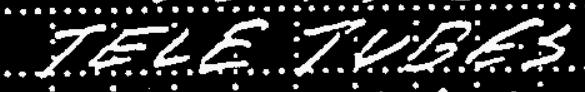

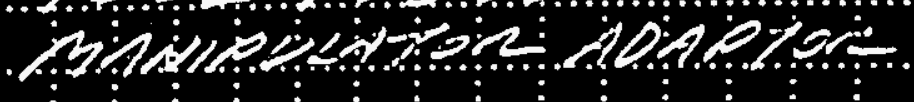

20

J

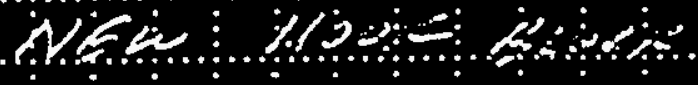

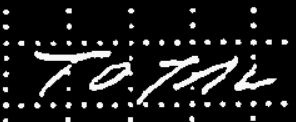

joe $20 \% \%$

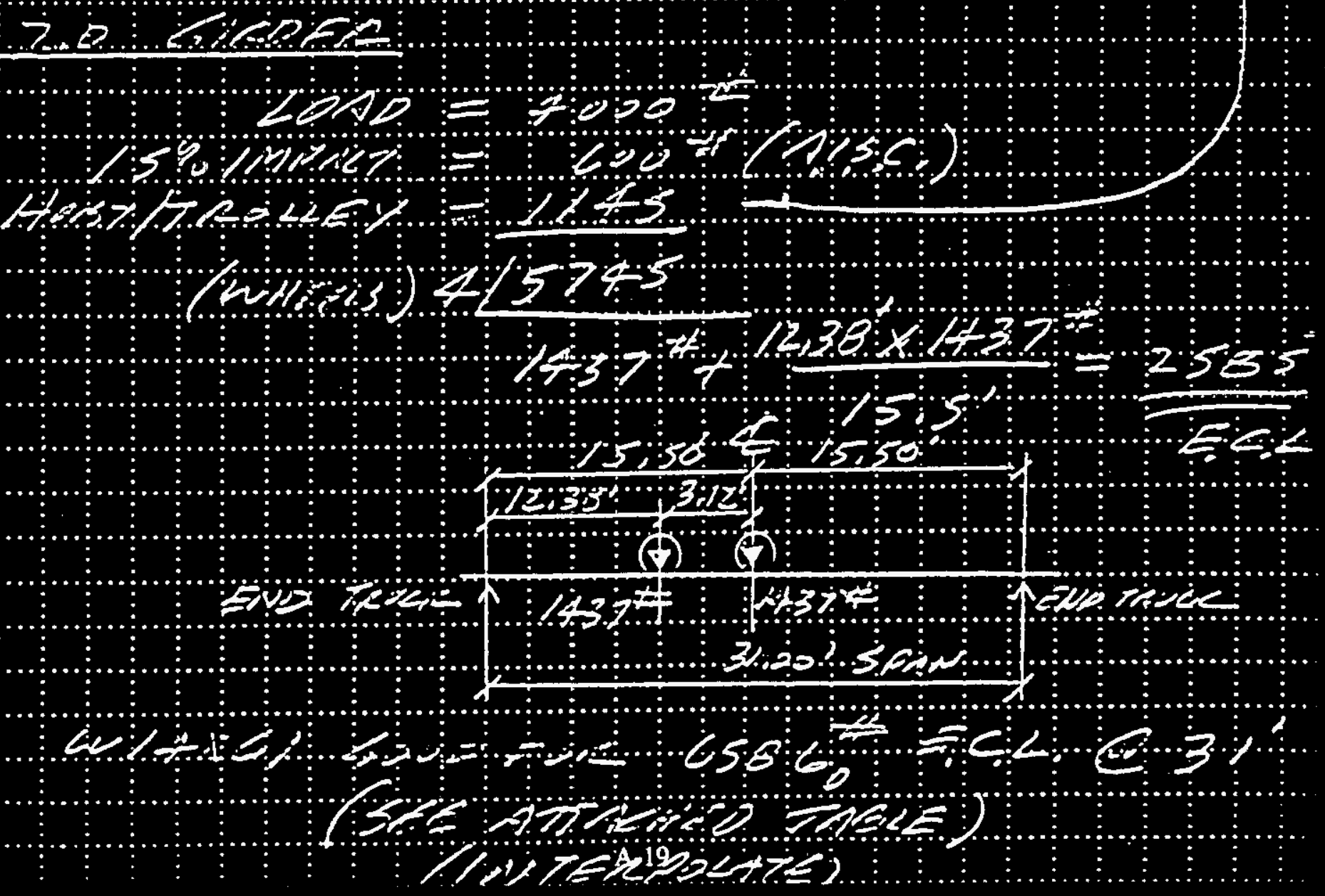


WHC-SD-SNF-DA-016, Rev. 0

THE BARTHOLOMEW COMPANY, INC. $A * 1$, Pg 2 of 28

PAGE OF.

91 NEW YORK AVENUE WESTEURY. N.Y. 11590 REMSION DATE Phon (516) $333-0100$ Fax (516) 333-0301 JOB NUMBER - CUSTOMER PREPARED BY TIRE DOCUMENT No. 950905 -

3

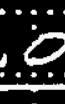

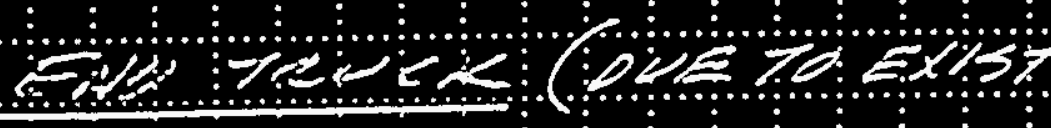

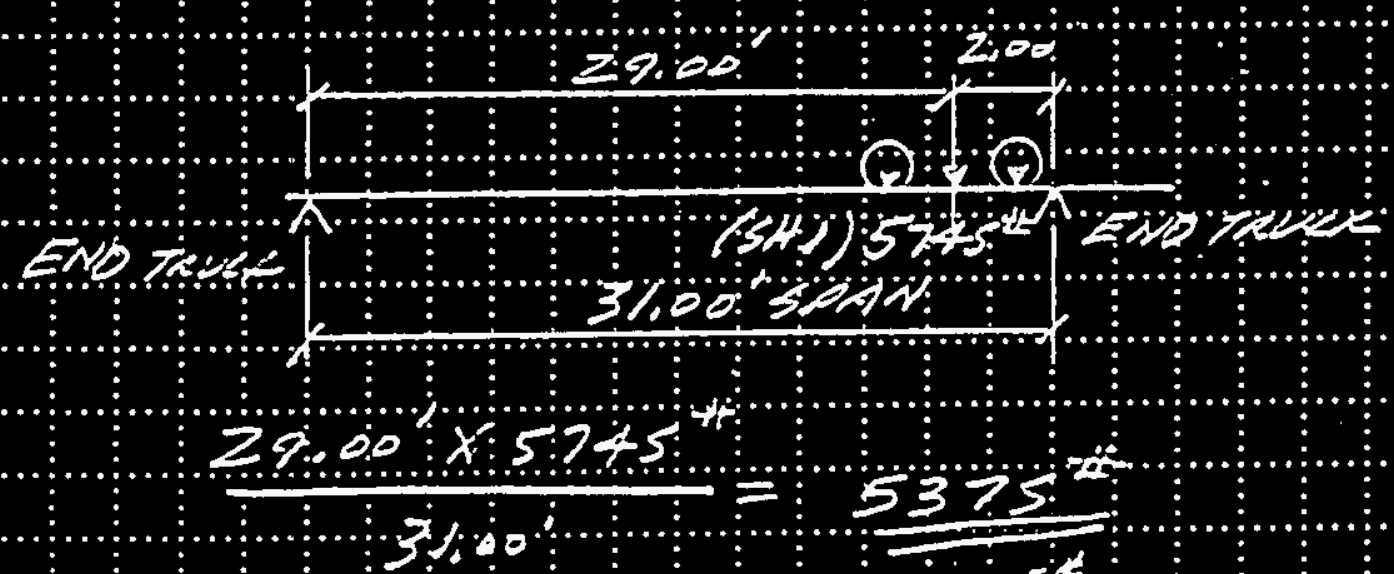

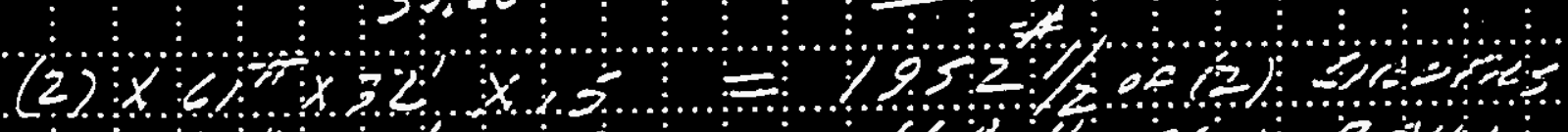

(2) $\times 5$ S

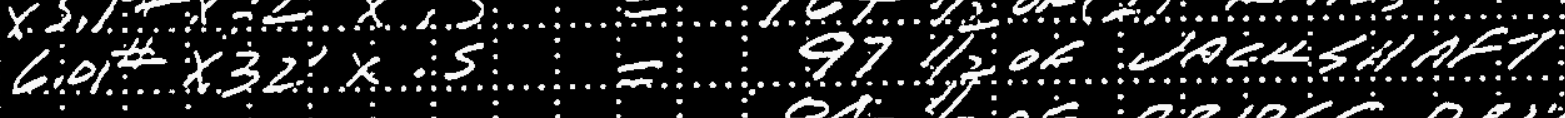

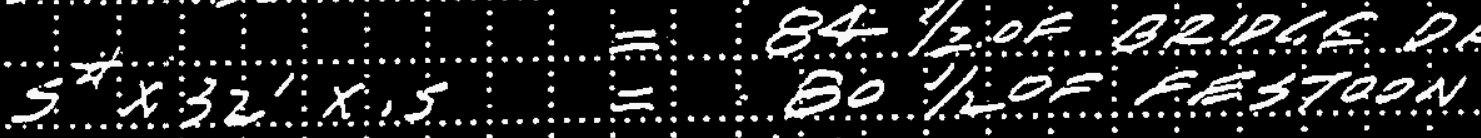

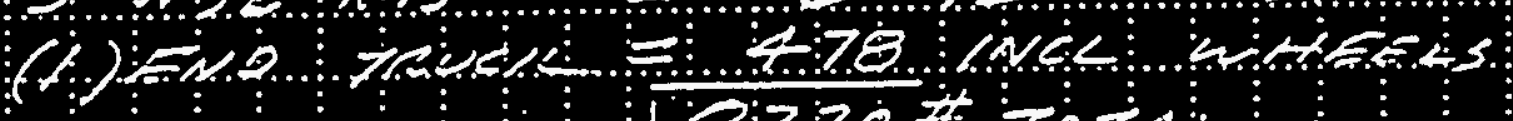

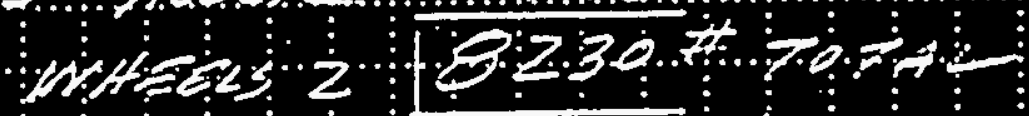

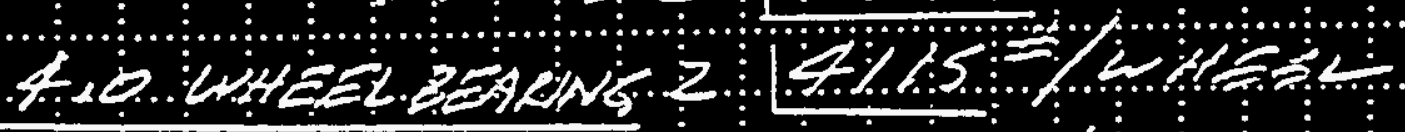
$2900 \times 000$ on $3 \% .00$ zed

mp or

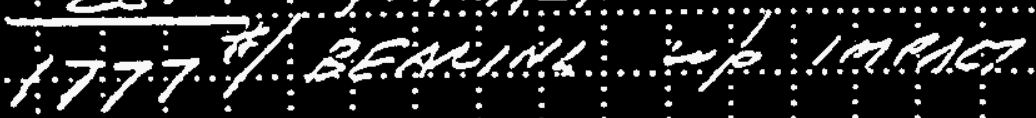

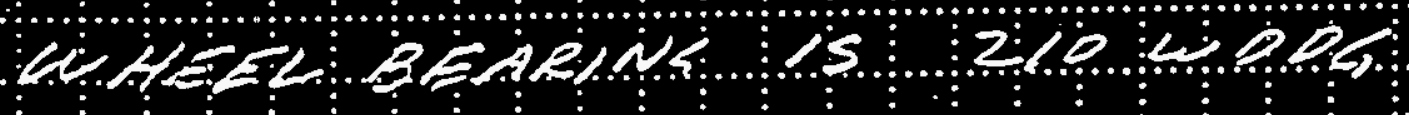

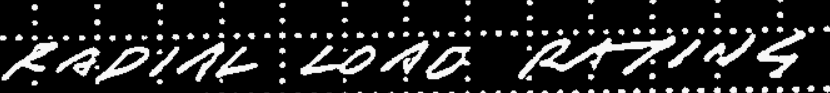
35:3 3 P

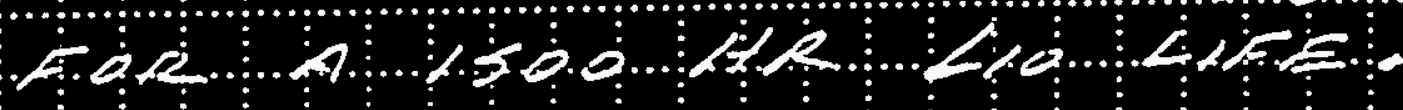

$A-20$ 


\section{THE BARTHOLOMEW COMPANY, INC.} 91 NEW YORK AVENUE WESTBURY. N.Y. 11590 Phom (516) $333-0100$

Fax (516) 335-0301

CUSTOMER

TIR
WHC-SD-SNF-DA-016, Rev. 0 AH I, Pg 3 of 28 PAGE 2 OF

REMSION DATE JOB NUMEER

- PREPAREO EY

DOCUMENT No. 950905

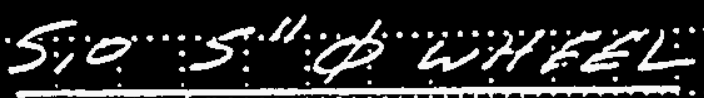

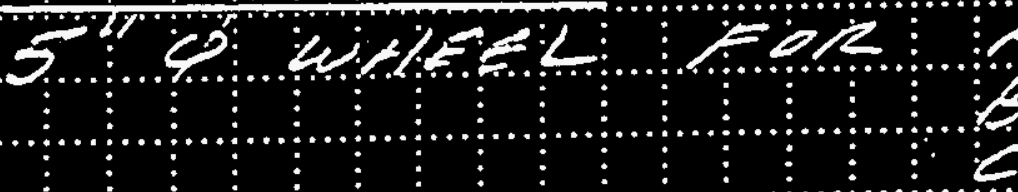

A 3 onos

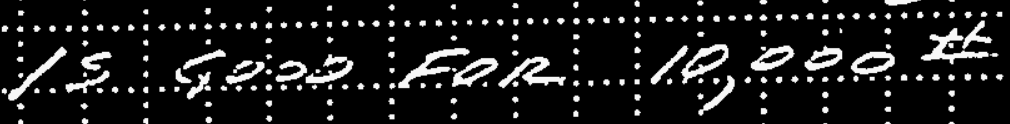

7oporits

ond

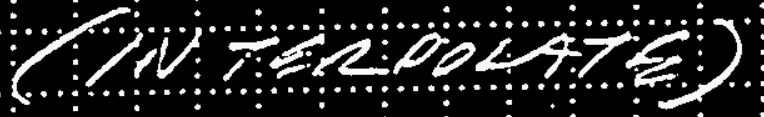


THE BARTHOLOMEW COMPANY, INC.

91 NEW YORK AVENUE WESTEURY, N.Y. 11590

Phone (516) 333-0100

Fax (516) $333-0301$

CUSTOMER

TIE

WHC-SD-SNF-DA-016, Rev. 0

AH 1, Pg 4 of 28

PACE \& OF

REMSION

DATE

JOB NUMBER

PREPARED BY

DOCUMENT No. $95090:$

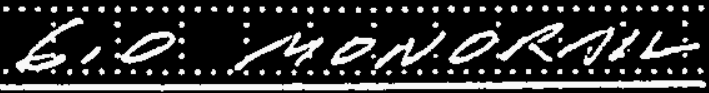

$4 x+20=40 p=7$

ort

$\frac{1}{5: 1 \%: 1 \%}$

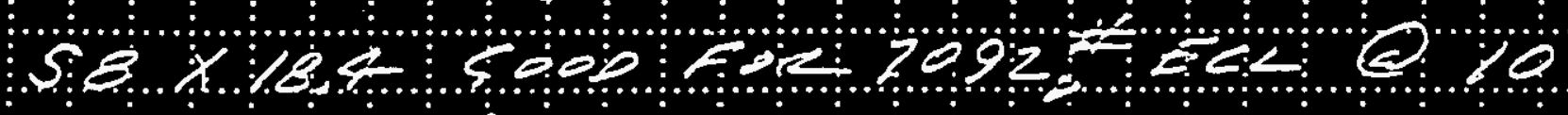

pry ex

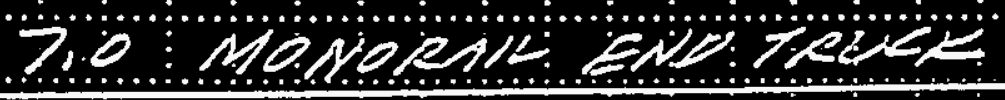

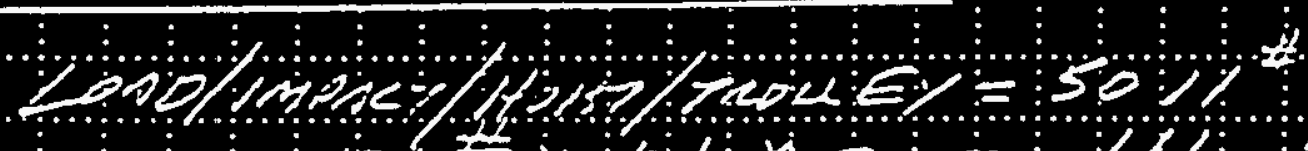

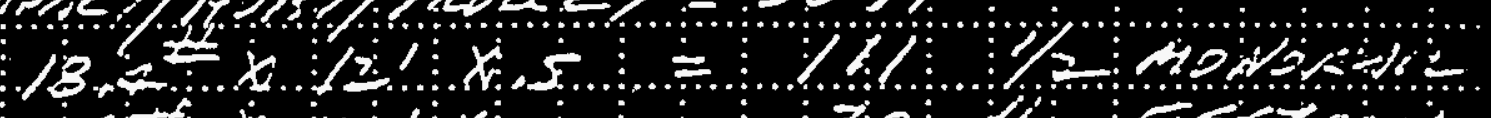

$$
\begin{aligned}
& \text { - > no } 1 / 2 \text { zs }
\end{aligned}
$$

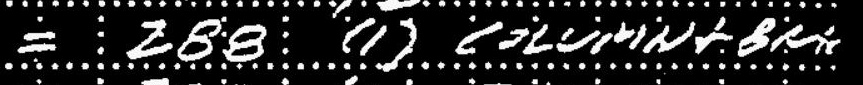

$$
\begin{aligned}
& =323 \text { (1) } \\
& \text { 25763-40 }
\end{aligned}
$$

Q.0.2. 20

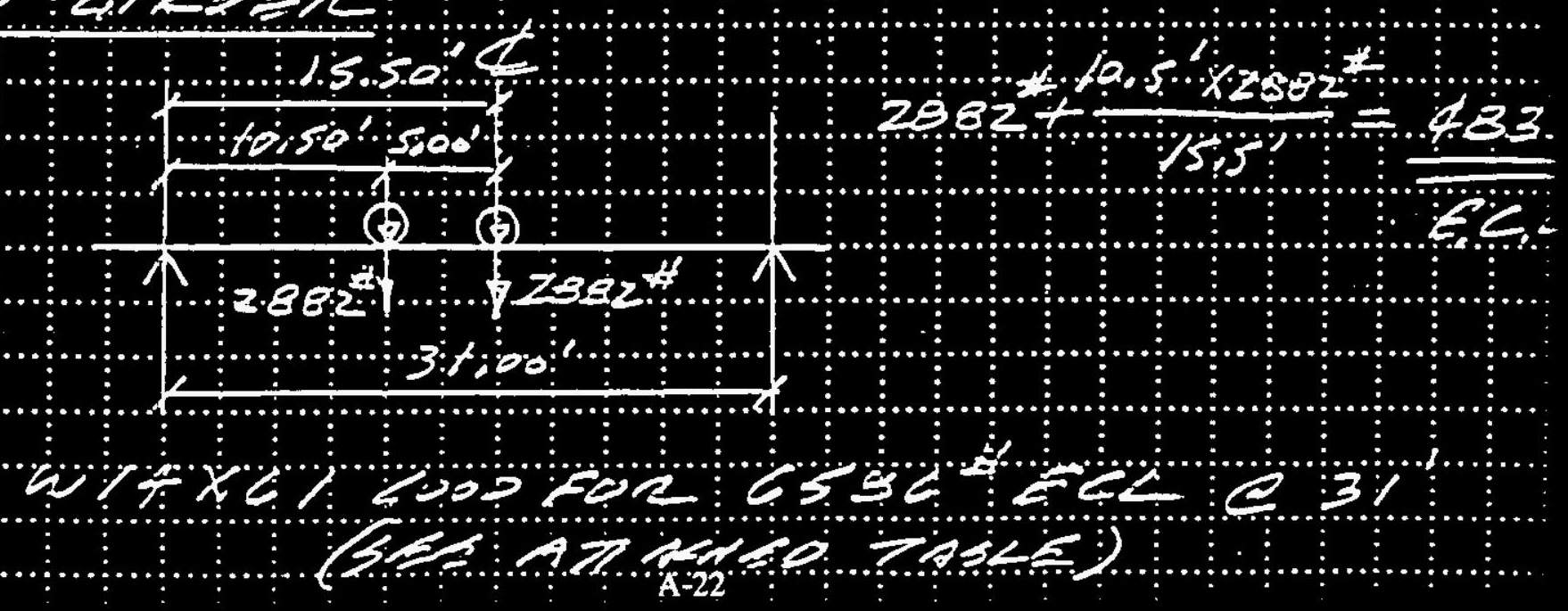





\section{THE BARTHOLOMEW COMPANY, INC.}

91 NEW YORK AVENUE WESTBURY, N.Y. 11590

Phons (516) 333-0100

$F a x(516) \quad 333-0301$

CUSTOMER

TII
WHC-SD-SNF-DA-016, Rev. 0 $A t+1, P g 6$ of 28

PAGE

REMSION DATE

JOB NUMBER

PREPARED EY

DOCUMENT No. 250 QRUS

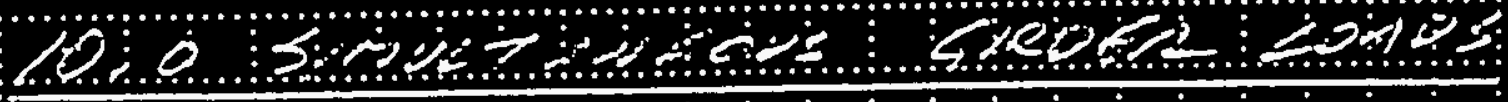

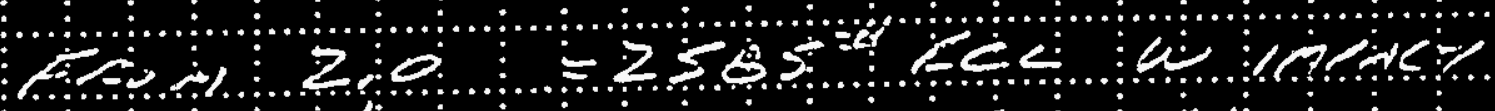

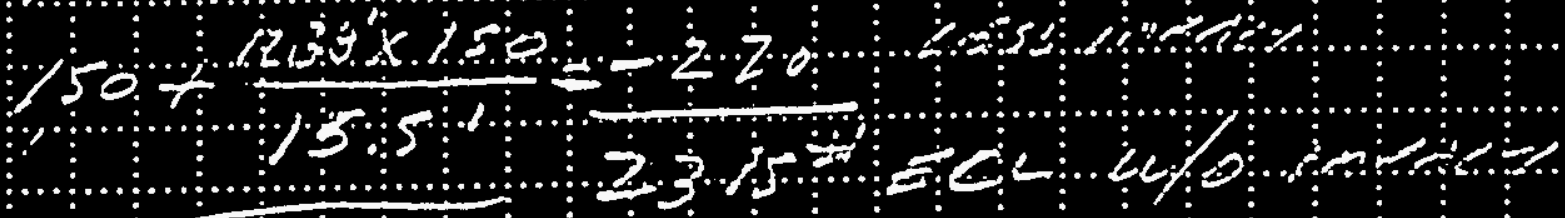

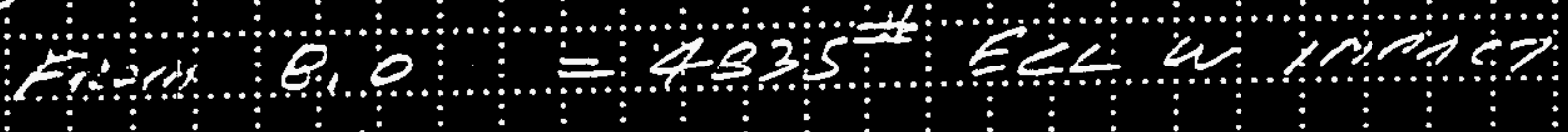

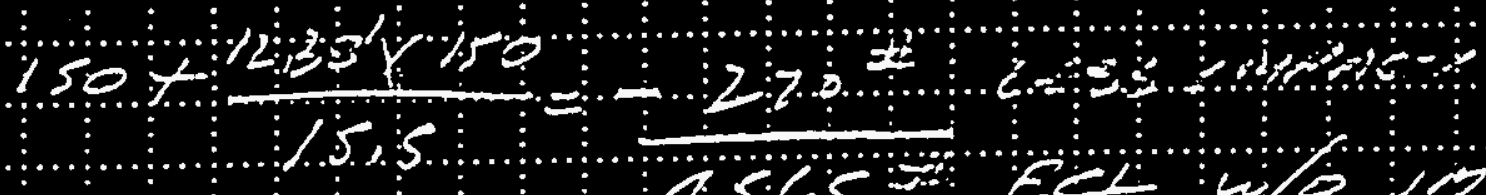

$4565 \%$ w w w

$235 \%+20=0$

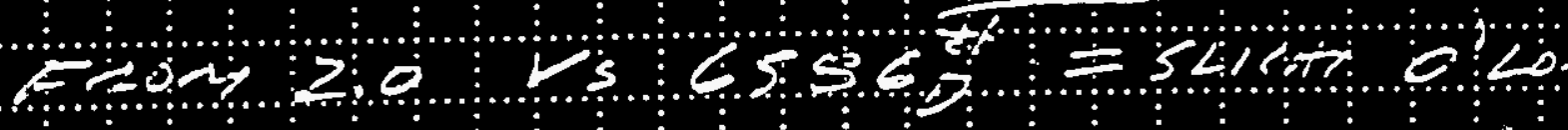

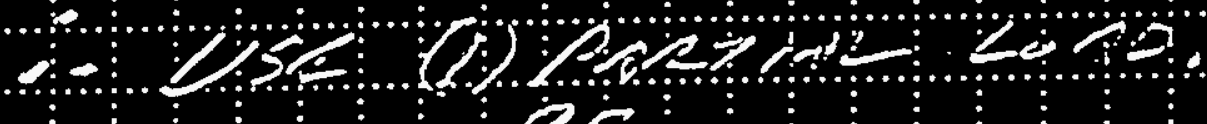

oj

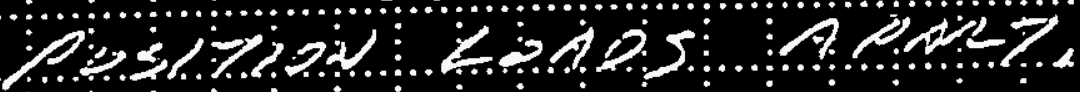


THE BARTHOLOMEW COMPANY, INC. 91 NEW YORK AVENUE WESTBURY, N.Y. 11590 Phone (516) $333-0100$

Fox (516) 333-0301

CUSTOMER $\pi \mathrm{m}$
WHC-SD-SNF-DA-016, Rev. 0 Att 1, Pg 7. of 28 PAGE $\longrightarrow$ of REVLON $\&$ DATEZSZL JOB NUMBER PREPARED BY DOCUMENT No. 952225

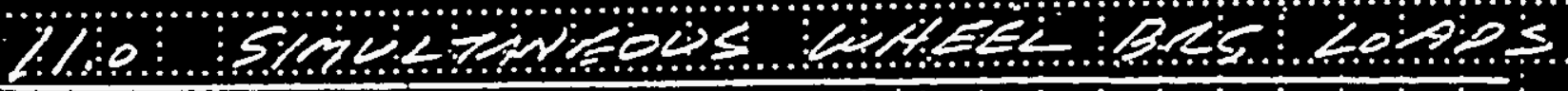

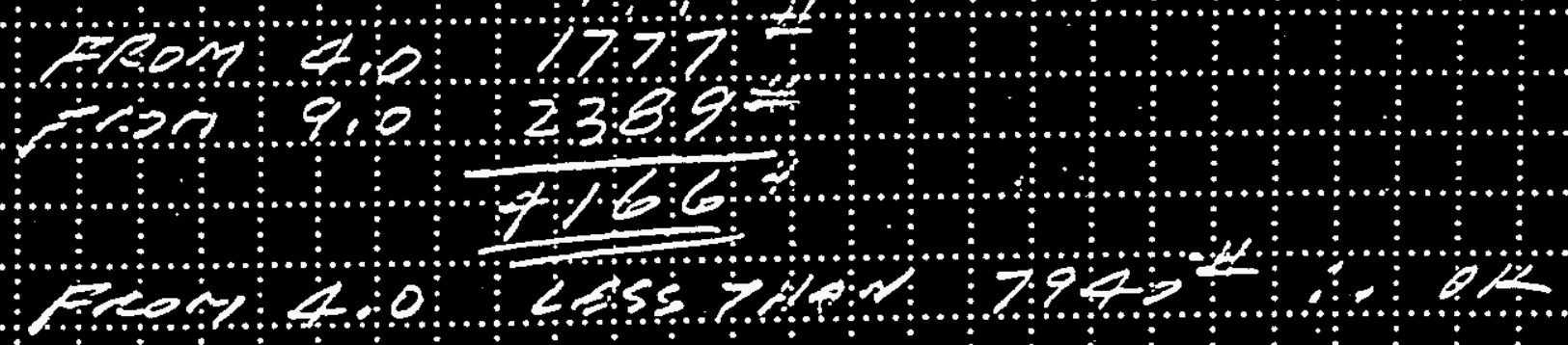

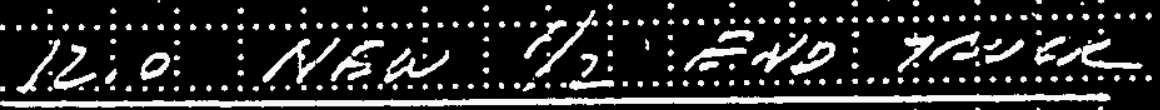

$$
\begin{aligned}
& \text { popomo }
\end{aligned}
$$

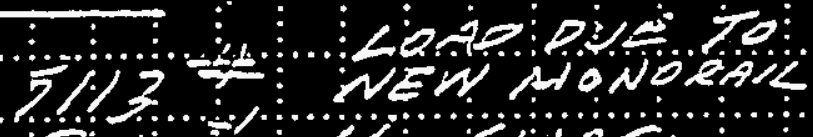

$$
\begin{aligned}
& \text { : } \\
& \text { 726: } 2156120= \\
& 1 \text { \% }
\end{aligned}
$$
6490 Th

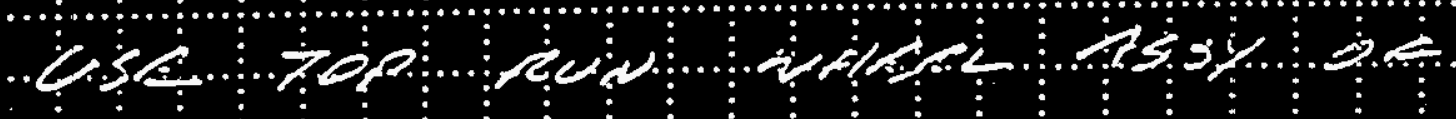

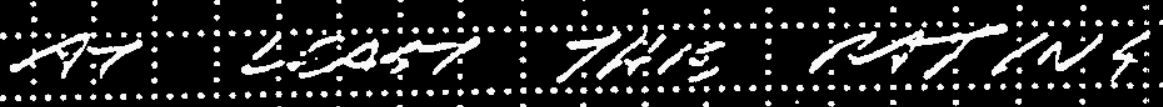


THE BARTHOLOMEW COMPANY, INC. 91 NEW YORK AVENUE WESTEURY, N.Y. 11590

Phono (516) 353-0100

Fox (516) 333-0301

CUSTOMER

mI
WHC-SD-SNF-DA-016, Rev. 0 At+ 1 , PS 8 gf 28

REMSION $A$ DATE $2 B \leq 20$ JOB NUMBER

PREPARED EY

DOCUMENT No. $350005=$

bo

reon

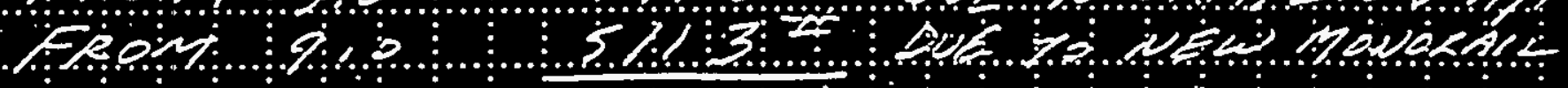
$92 z 8$

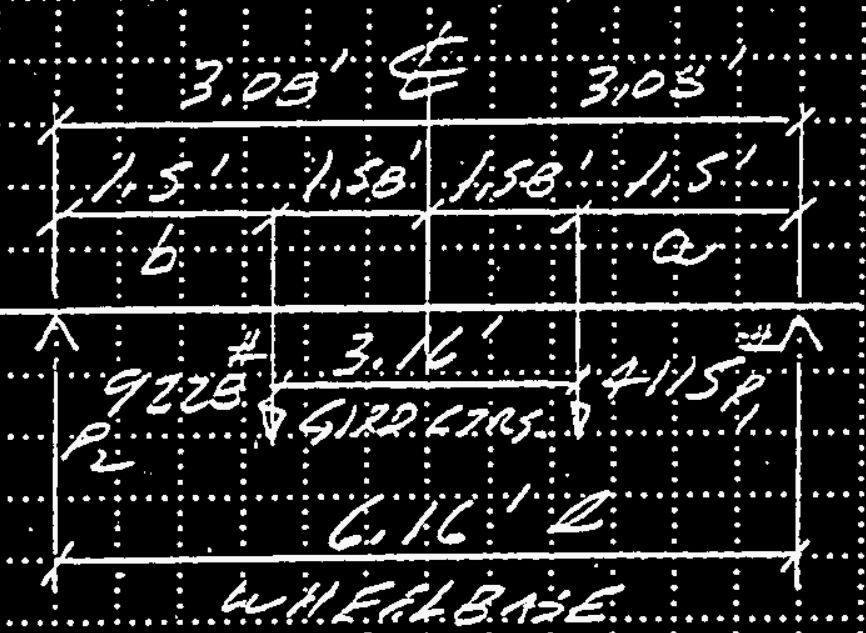

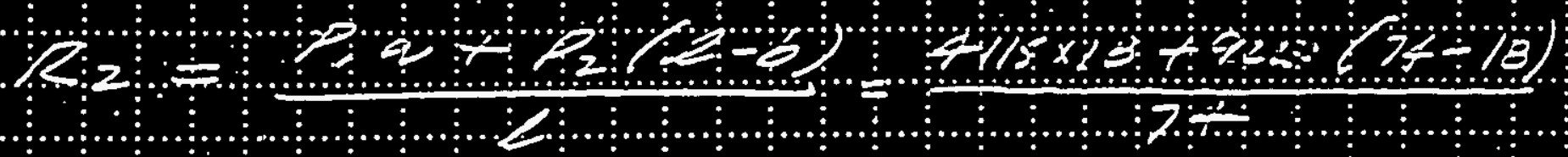

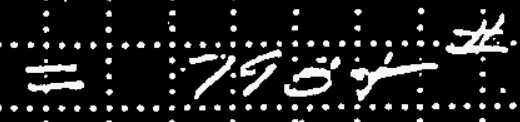

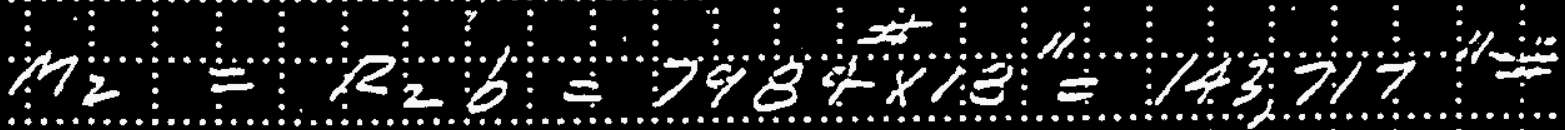
Squ - 
THE BARTHOLOMEW COMPANY, INC. 91 NEW YORK AVENUE WESTBURY, N.Y. 11590 Phons (510) 333-0100 Fox (516) 333-0301
WHC-SD-SNF-DA-016, Rev. 0 At+ 1, 99 gof 28

PAGE

REVIION $C$ DATELOCZ JOB NUMBER

PREPARED EY

DOCUMENT No. $950 \% 05$

MIL

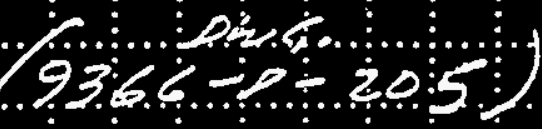

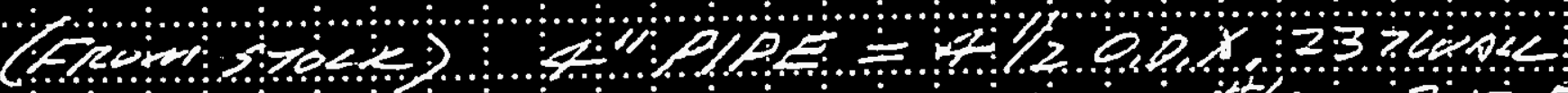
:

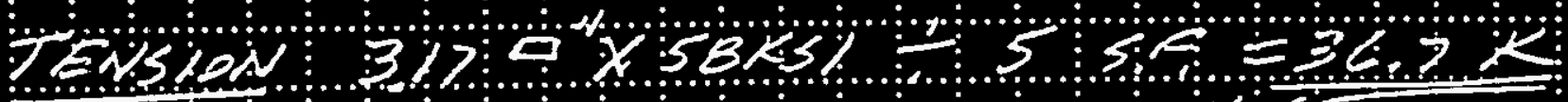

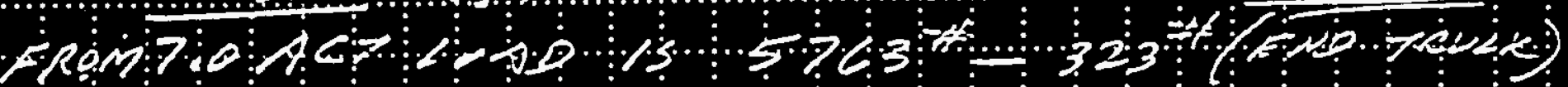

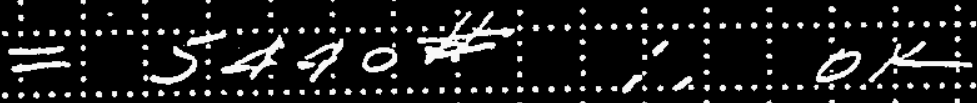

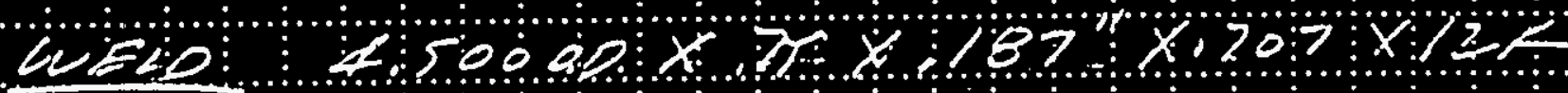

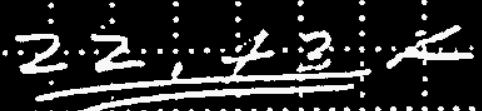

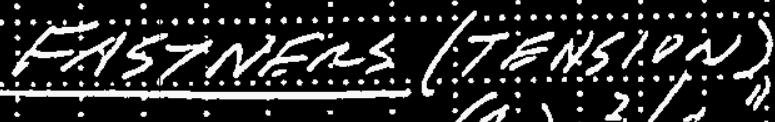

(7)

$(4)$

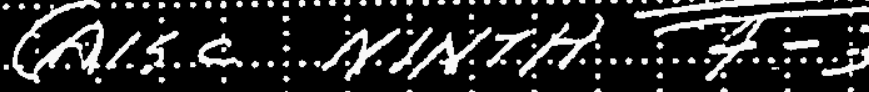

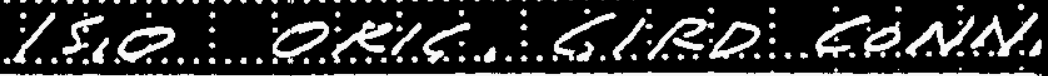

Aijis

(1)

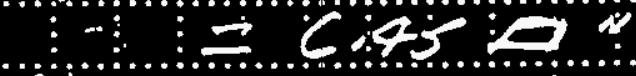

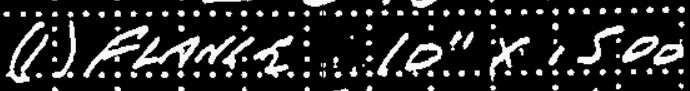

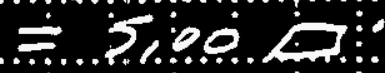

(l)ken

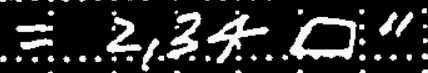

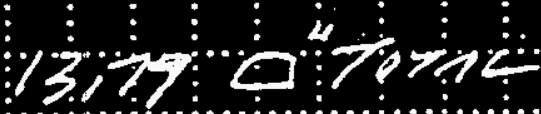

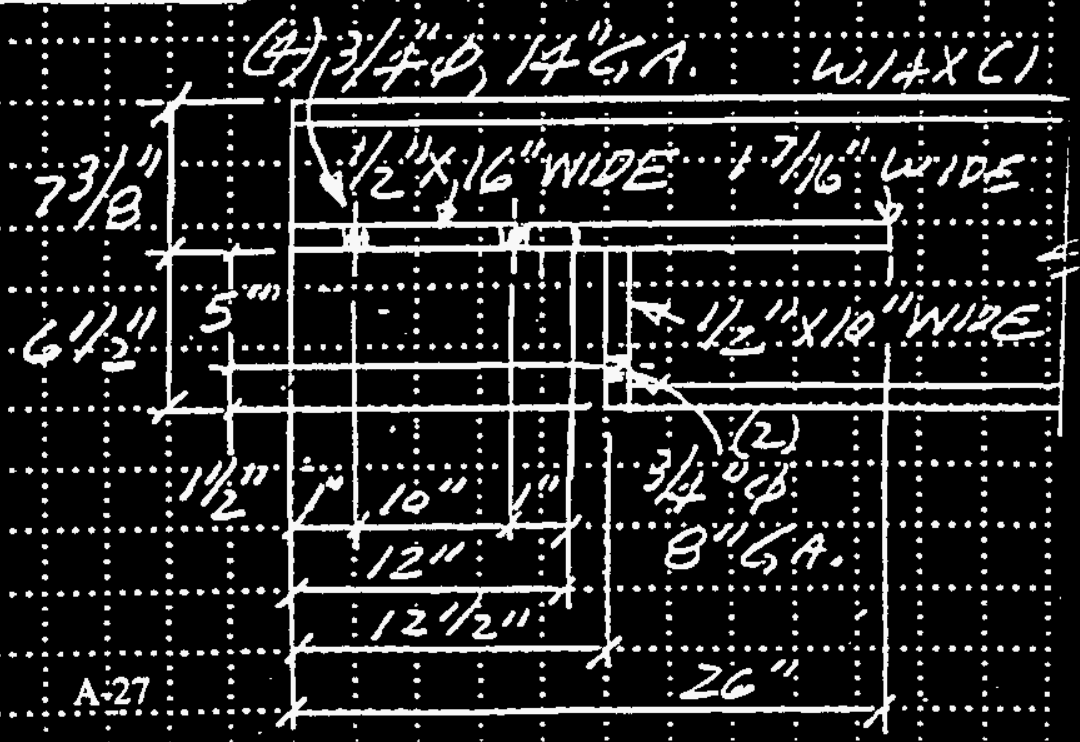


WHC-SD-SNF-OA-016, Rev. 0
$A+t 1,09$, of 28

THE BARTHOLOMEW COMPANY, INC.

91 NEW YORK AVENUE WESTEURY. N.Y. 11590

CUSTOMER

MILE.
Phon (516) 333-0100

Fax (516) 333-0301

$\frac{150}{1000 \%}$
PACE $1 / B^{\circ}$ OF

REM SION $\angle$ DATE 100 OC Y

JOB NUMBER

PREPARED EX

Document No. $12-205$

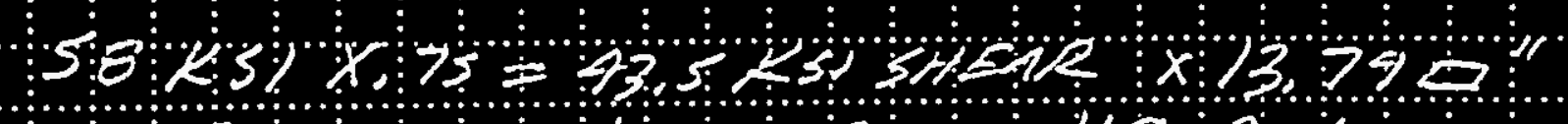

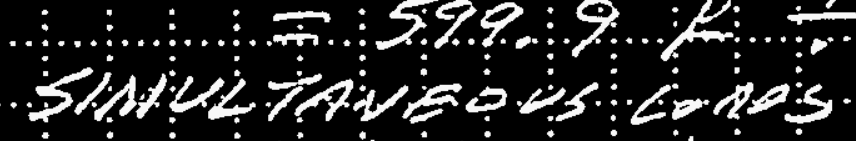

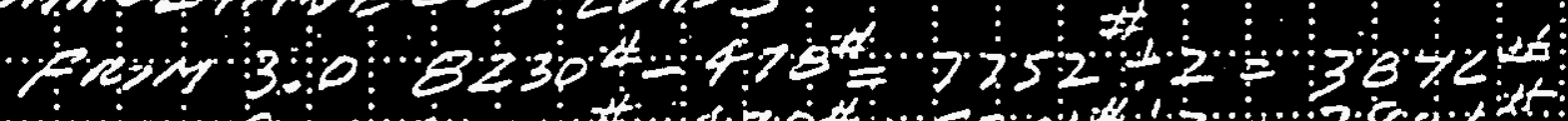

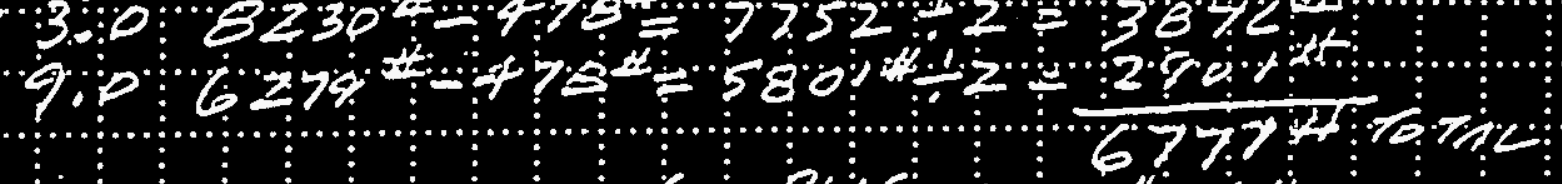

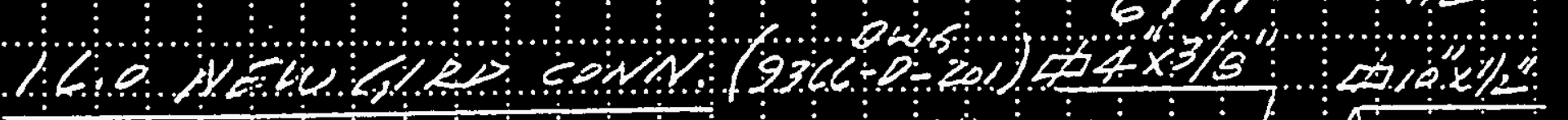

AR efl

(2) $=250 \times 10$

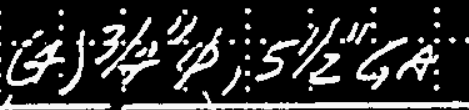

$4 / 2)^{2}$

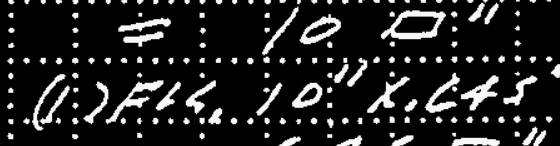

doter es

Q

\&"

(1) Hes Z

id y

$=24+4$

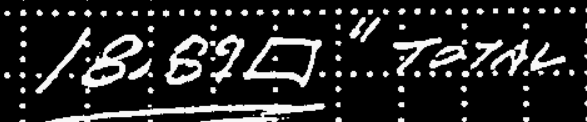

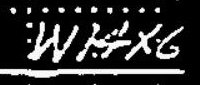

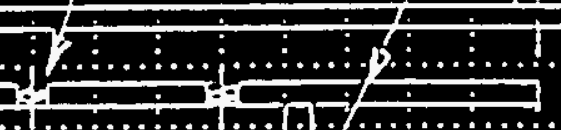

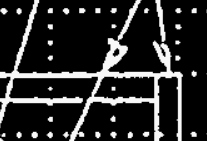

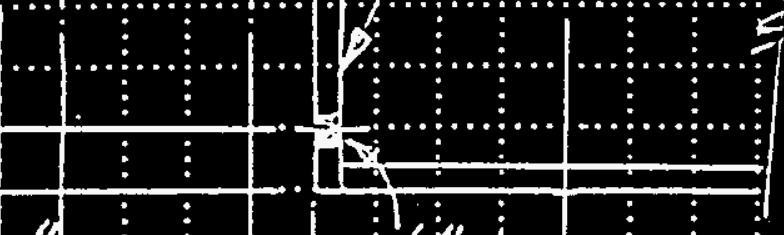

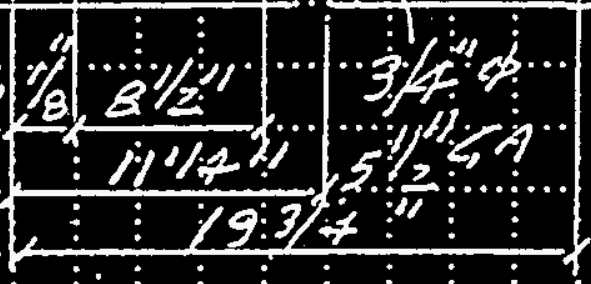

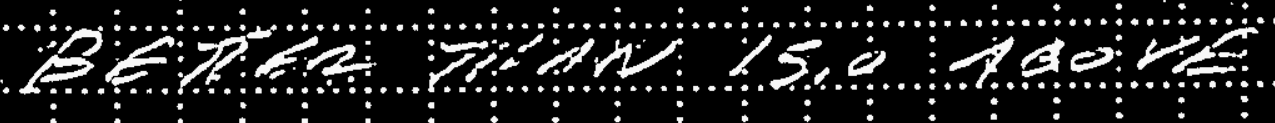

A:28: 
THE BARTHOLOMEW COMPANY, INC.

91 NEW YORK AVENUE WESTBURY, N.Y. 11590 Phone (516) $233-0100$

CUSTOMER TILE

Fox (516) 353-0301
Att 1 C-SD-SNF-DA-016, Rev.

PACE $11 / 28$ OF

REViSION $\angle$ DATE 10 OCT

JOB NUMBER

PREPARED BY

DOCUMENT No. $950805-$

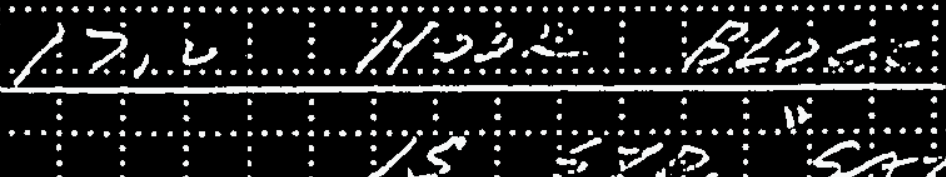

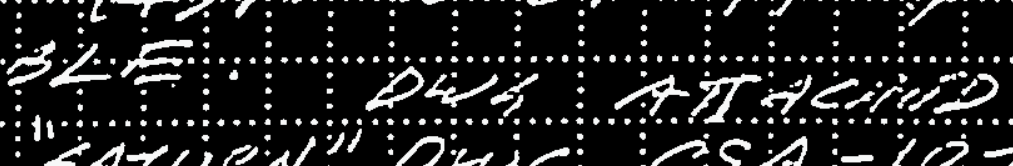

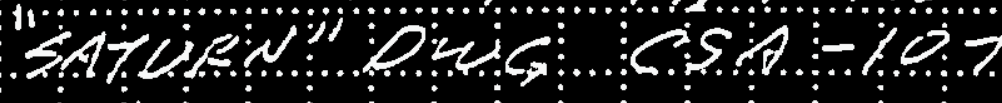

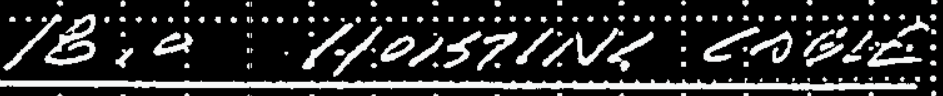

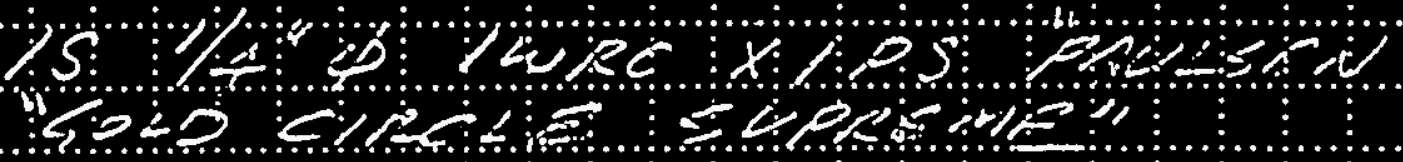

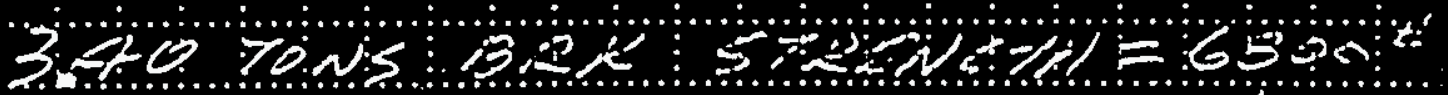

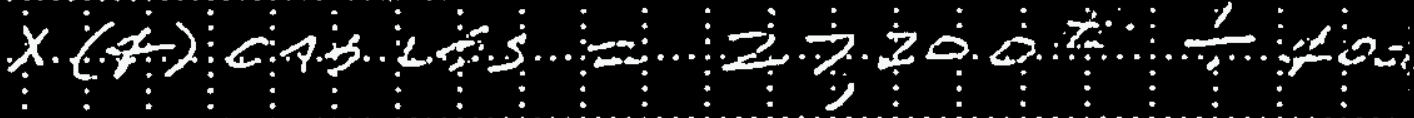

$$
\begin{aligned}
& =6,3, \ldots
\end{aligned}
$$

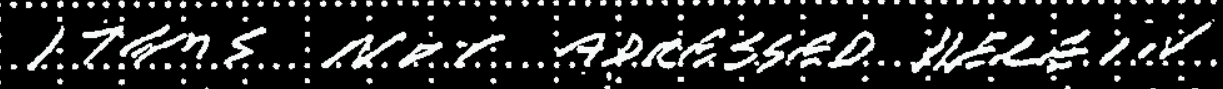

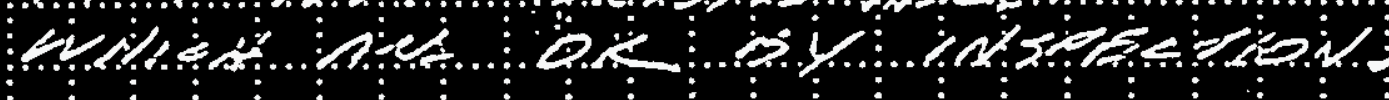

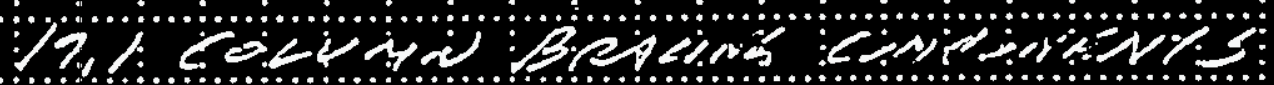

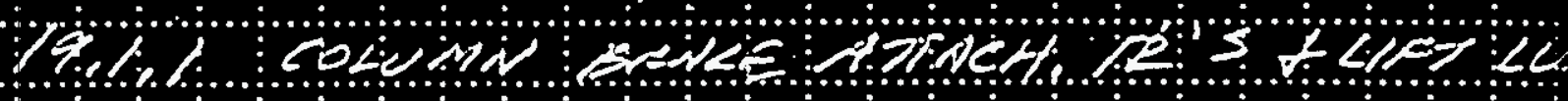
$904360-0-205$

\% $04936-0-262$

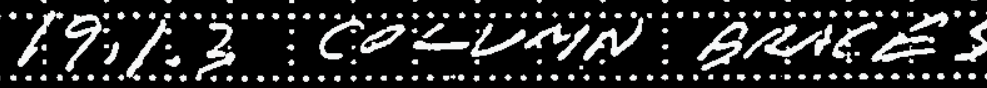

$046936<-0-303-2,29$

(AL 30 is 
THE BARTHOLOMEW COMPANY, INC. 91 NEW YORK AVENUE WESTEURY, N.Y. 11590 Phom (516) 353-0100
WHC-SD-SNF-DA-016, Rev. 0 PAGE 12 OF 28

REMSION $A$ DATE $205 A 9 \%$

JOB NUMBER $23 \mathrm{CL}$

PREPARED EY

Document No. $95 / 224 \mathrm{E}$ -

\section{Tins

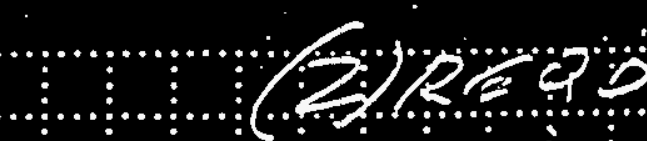 \\ $4 \%$ \%}

CUSTOMER WEST KIANLRRO

2)

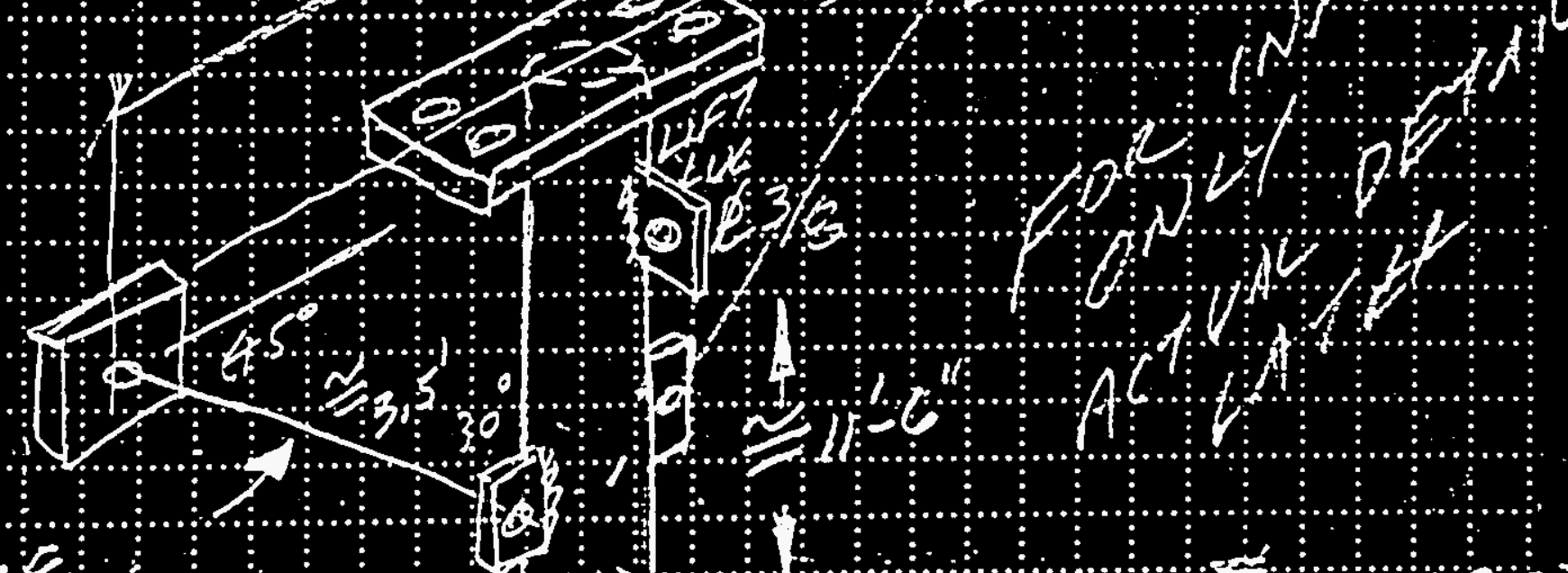

of

Ala

$\% 0$ 1:

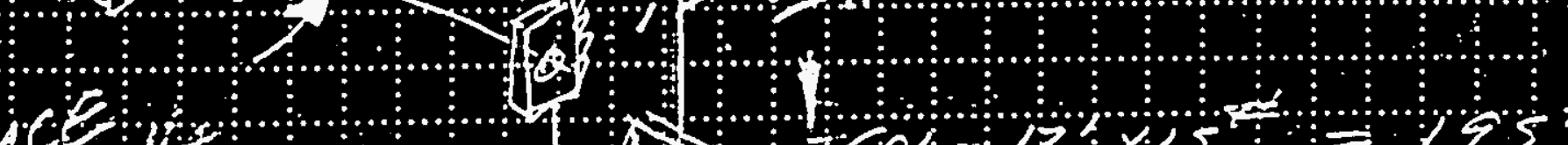

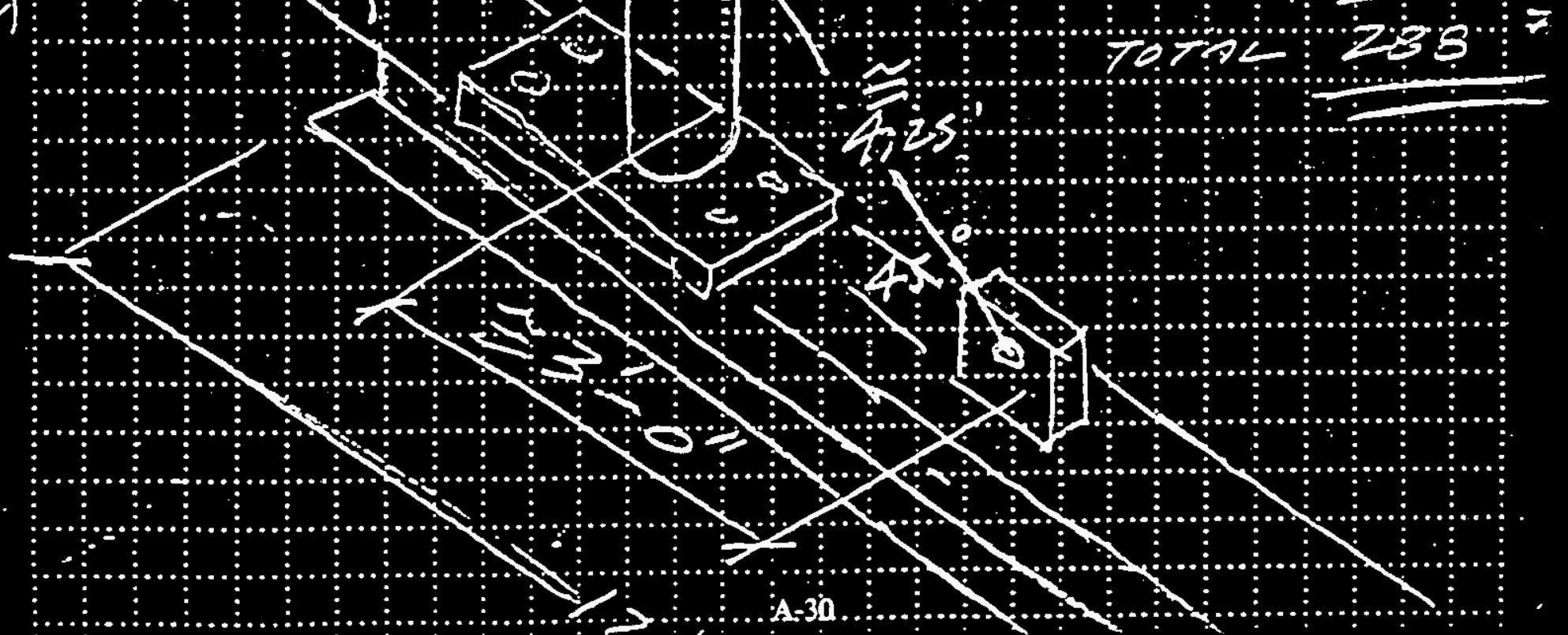


WHC-SD-SNF-DA-016, Rev. ' 0

Att. 1, pg 13 of 28

\section{URAIHHT STRUCTURAL BEAM DESIGN GUIDE AND \\ SELECTION CHART FOR OVERHEAD CRANE RUNWAY SYSTEMS}

AFFI Hoist \& Crane Division 


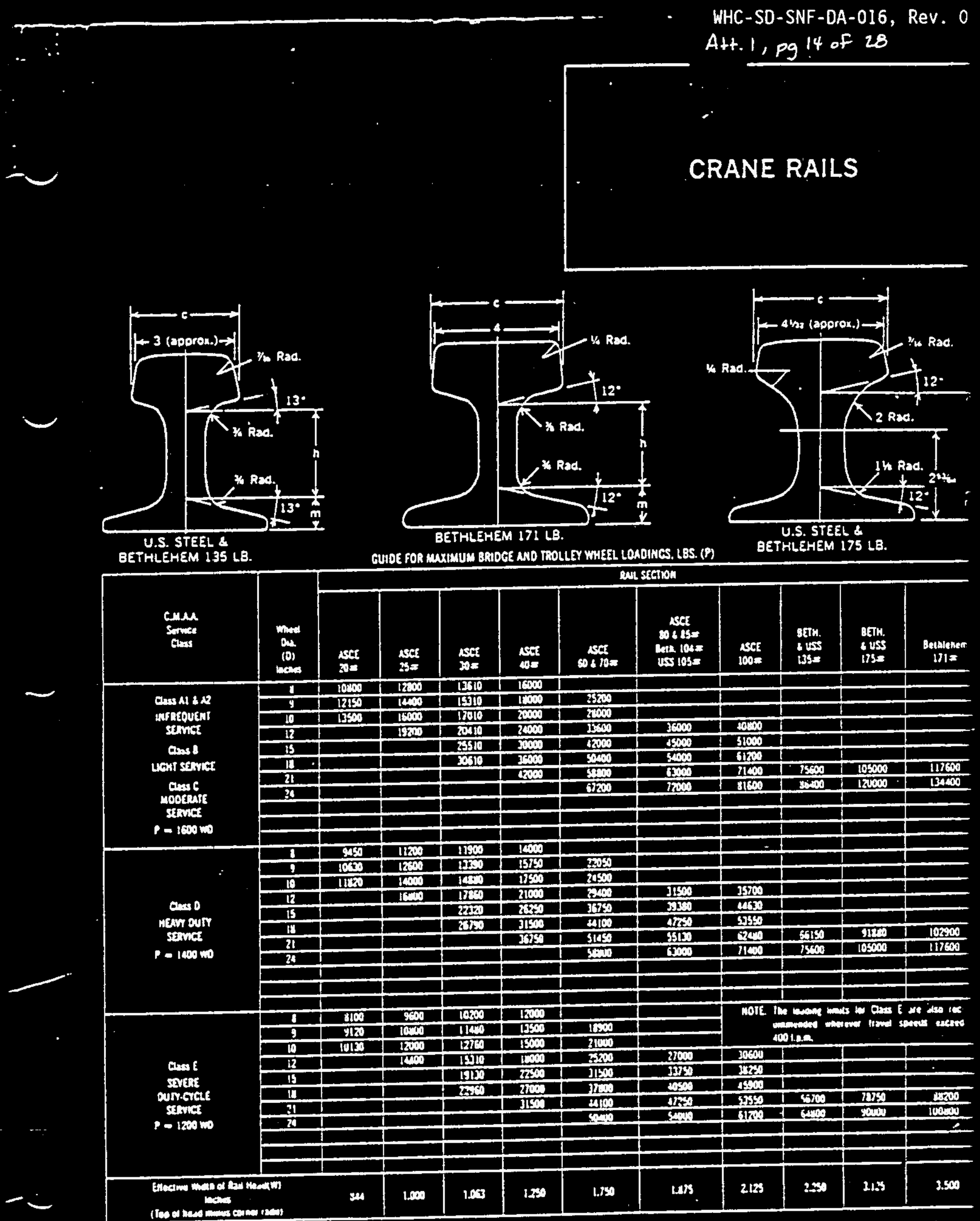

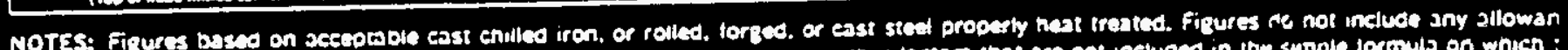

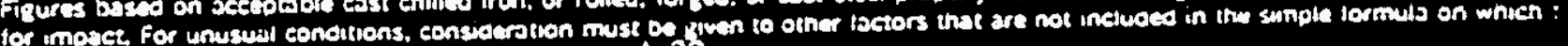

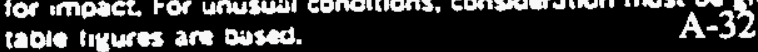




\title{
Light
}

\author{
200 Series
}

\section{Load Ratings}

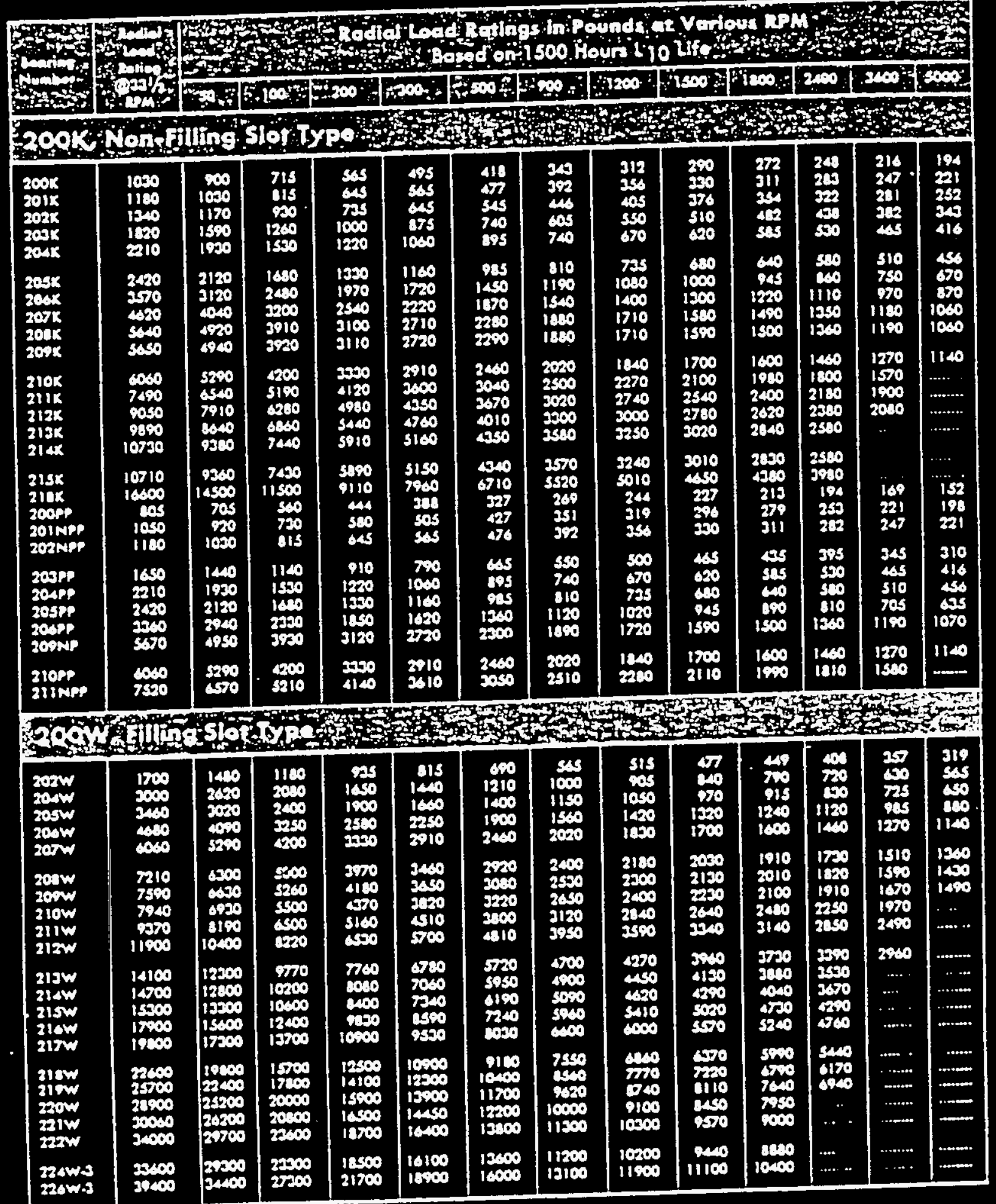




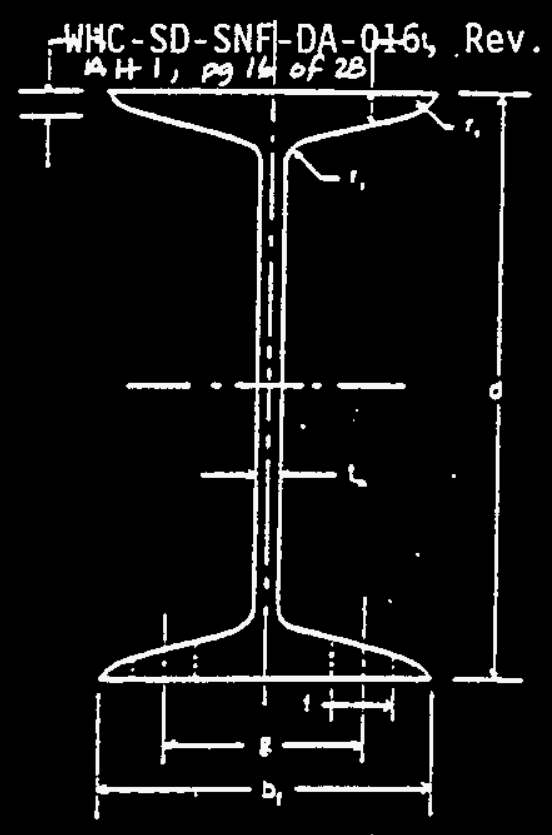

\begin{tabular}{|c|c|c|c|c|c|c|c|c|c|c|c|c|c|c|c|c|}
\hline $\begin{array}{l}\text { Seztona } \\
\text { Oestifation } \\
\text { Nember }\end{array}$ & $\begin{array}{c}\text { Depth } \\
\text { of } \\
\text { Section }\end{array}$ & $\begin{array}{l}\text { Nitiont } \\
\text { ont } \\
\text { foof }\end{array}$ & $\begin{array}{c}\text { Nuea } \\
\text { Section }\end{array}$ & Whet & $\begin{array}{l}\text { Ftange } \\
\text { riont: }\end{array}$ & $\begin{array}{l}\text { Flange } \\
\text { Avertse } \\
\text { Phicknets }\end{array}$ & $\begin{array}{l}\text { Hea } \\
\text { of } \\
\text { Ponge }\end{array}$ & $\frac{d}{4}$ & \multicolumn{3}{|c|}{$\begin{array}{c}\text { Elastik Prosenties } \\
\text { Aris } x-x\end{array}$} & $\begin{array}{c}\text { Fisans } \\
\text { Nomual } \\
\text { Thichnass } \\
\text { at Tor }\end{array}$ & $\begin{array}{c}\text { Radius } \\
\text { it } \\
\text { Toe }\end{array}$ & $\begin{array}{l}\text { Radicas } \\
\text { if } \\
\text { fillat }\end{array}$ & $\begin{array}{l}\text { Usual } \\
\text { Plapase } \\
\text { Gate }\end{array}$ & $\begin{array}{l}\text { Marinom } \\
\text { Flante } \\
\text { Pastenes }\end{array}$ \\
\hline & 10 & & $A$ & $b$ & $b_{1}$ & $t_{1}$ & 1 & & 1 & 5 & I & 4 & $P_{1}$ & 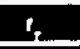 & 8 & $t$ \\
\hline & in. & b. & in? & in. & in. & a. & in. ${ }^{2}$ & & i. & in. ${ }^{3}$ & in. & in. & in. & in. & in. & in. \\
\hline $554 i 2.5$ & 16.0 & 32.5 & 3.67 & 0.232 & 3.532 & 0358 & 1.196 & 5.02 & 22.1 & 7.37 & 2.45 & i & .14 & 33 & 2 & *ै \\
\hline 55117.35 & 6.0 & 17.25 & 5.07 & 0.465 & 3.585 & 0.359 & 1280 & 4.69 & 26.3 & 8.77 & 228 & is & .14 & 33 & 2 & Fi \\
\hline $57 \times 15.3$ & 7.0 & 13.3 & 150 & 0.252 & 3.653 & 0.392 & 1.435 & 4.88 & 36.7 & 10.5 & 2.86 & 8 & .15 & 35 & 234 & $\frac{4}{3}$ \\
\hline SE!!E.4 & 8.0 & 18.4 & 54 & 0.271 & 4.091 & 0425 & 1.700 & 4.70 & 57.6 & 141 & 3.26 & $1 / 4$ & .16 & 37 & 236 & 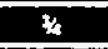 \\
\hline $56 \times 5$ & 8.0 & 23.0 & 8.17 & $0.46 !$ & 4.171 & 0.425 & 1.773 & 4.51 & 24.9 & 162 & 3.10 & 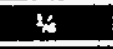 & .16 & 37 & 23 & 4 \\
\hline $510 \times 254$ & 10.0 & 25.4 & 716 & 0.511 & 9681 & 0491 & 2385 & 437 & 124 & 24.7 & 4.07 & tis & .19 & $4 !$ & $23 i$ & $y$ \\
\hline $510 \times 35$ & 10.0 & 350 & 10.3 & 0.594 & 4.944 & 0491 & 2.428 & 6.12 & 117 & 28.4 & 3.78 & $\Sigma_{16}$ & .19 & 41 & $2 y$ & 4 \\
\hline Si2k31.8 & 12.0 & 31.8 & 935 & 0.350 & 5.000 & 0.514 & 2.720 & 4.61 & 218 & 36.4 & 1.83 & 4 & 21 & 45 & 3 & 4 \\
\hline $5: 2436$ & 12.0 & 350 & 10.3 & 0428 & 5.078 & 0.541 & 2.762 & 434 & 229 & 38.2 & 1.72 & 3 & 21 & 45 & 3 & 4 \\
\hline $512 \times 40.8$ & 12.0 & 40.8 & 12.0 & 0.462 & 5252 & 0.659 & 3.461 & 3.06 & 272 & 45.4 & 4.71 & ?ho & 28 & 56 & 3 & 4. \\
\hline $5: 2 \times 50$ & 12.0 & 56.0 & 14.7 & 0.537 & 5.477 & 0.659 & 3.619 & 3.32 & 305 & 50.8 & 4.55 & ine & 28 & .5 & 3 & 3 \\
\hline $519 x+29$ & 15.0 & 129 & 12.6 & 0.411 & 5.501 & 0.222 & 3.422 & 438 & 417 & 59.5 & 5.95 & 30 & 25 & 51 & 345 & $3 i$ \\
\hline S:SESO & 15.0 & 50.0 & 14.7 & 0.35 & 5.640 & 0.522 & 3.508 & 128 & 435 & 6.8 & 5.75 & $k_{k}$ & 25 & 51 & $34 h$ & 3 \\
\hline SH3254.7. & 18.0 & 5.7 & 16.1 & $0.46 !$ & 6.001 & 0.691 & 4.147 & 134 & 804 & 89.4 & 7.07 & 3is & 23 & .56 & 34 & 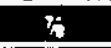 \\
\hline 518270 & 18.0 & 70.0 & 206 & $0.71:$ & 6.251 & 0.691 & 6319 & 4.17 & 926 & 303 & 6.71 & $x_{10}$ & .28 & .56 & $3 h$ & 3 \\
\hline $530 \times 65.1$ & 20.0 & 63.4 & 19.2 & 0.500 & 6250 & 0.789 & 4.931 & 4.05 & 1180 & 118 & 7.4 & ive & 39 & 80 & 34 & 8 \\
\hline 523.75 & 200 & 75.0 & 22.1 & 0.011 & 6.391 & 0.789 & 5.042 & 3.96 & 1280 & 128 & 1.50 & is & 30 & .60 & 39 & 3 \\
\hline 530285 & 20.0 & 25.0 & 250 & 0.659 & 7.053 & 0.916 & 6460 & 3.09 & 1320 & 152 & 1.79 & 4 & .36 & .70 & 1 & 1 \\
\hline $505 \times 95$ & 20.0 & 980 & 27.9 & 0.250 & 7200 & 0.916 & 6.595 & 3.03 & 1610 & 161 & 7.60 & 4 & 36 & 70 & 4 & 1 \\
\hline 594.75 .9 & 280 & 79.9 & 235 & 0.501 & 7601 & 0.871 & 6098 & 3.9 & 2110 & i75 & 9.47 & 4 & .30 & .60 & 4 & 1 \\
\hline $53: 180$ & 130 & 90.0 & 26.5 & 0.624 & 7.124 & $0.87 !$ & 8.265 & 3.67 & 2280 & 107 & 9.22 & 4 & 30 & 60 & 1 & 1 \\
\hline $5: 2100$ & 260 & 100.0 & 29.1 & 0.717 & 7247 & 0.871 & 6.312 & 3.80 & 2390 & 199 & 8.01 & 4 & .30 & 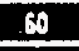 & 4 & 1 \\
\hline 526.165 .9 & 128.0 & 105.9 & 38.1 & 0.625 & 7.675 & 3.102 & 8.678 & 2.77 & 2638 & 236 & 8.53 & $13_{\text {is }}$ & 30 & 80 & 4 & 1 \\
\hline 524.130 & 240 & 129.0 & 35.3 & 0.798 & 8.048 & 1.102 & 8.869 & 2.71 & 3030 & 252 & 9.36 & $1_{\text {iv }}$ & 30 & .00 & 4 & 1 \\
\hline
\end{tabular}

NOT:5

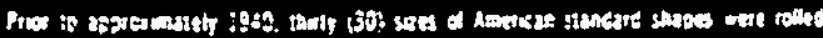

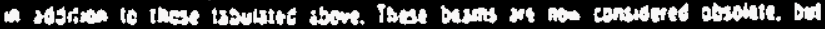

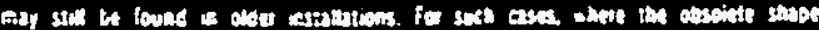

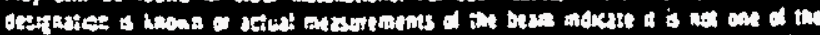

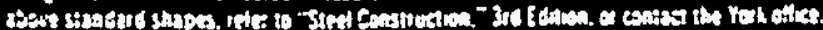

\section{aruaners:}

maraual of Stcel Construetion." Serenth Edition, Anezican Iastitule of Stcel Construction. Ine, Kew Yeeh, 1970.

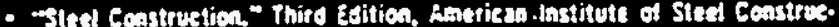
tion, the. Kew Yoxh, 1937.

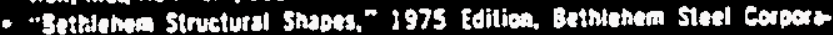
tion. Bothlothan, Po., 1975.

- "Bothichen Strutural Shapes," 1962 Edition, Bothizhem Sted Coxpors tion, Enthichem, P2., 1962. 
Lowe thange losdings tabulated below are based on static foad and do not consider serviec. Spating between whed eenters must be equal to or grester than total flange witth. All lasting figures shown are in pounds.

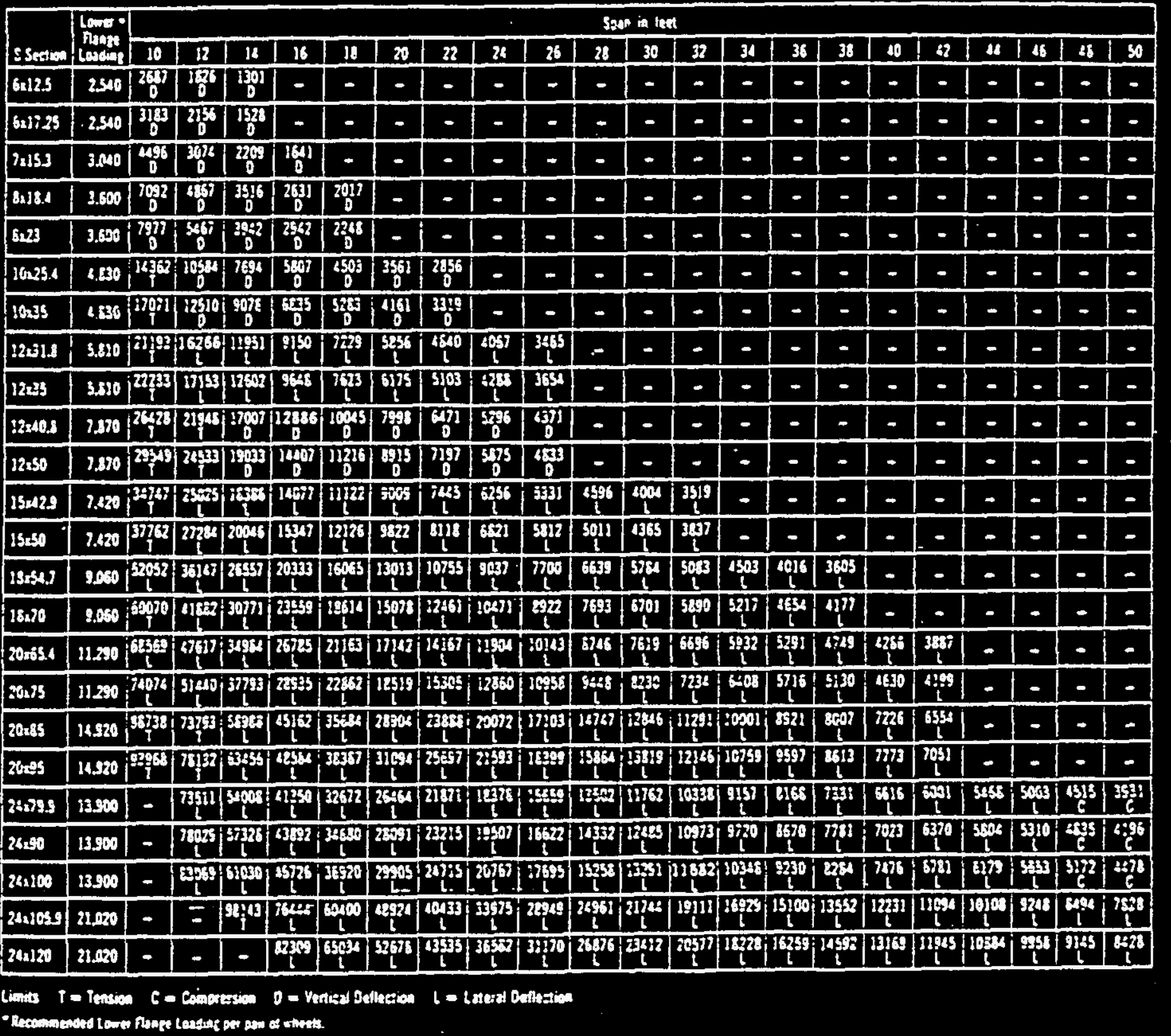



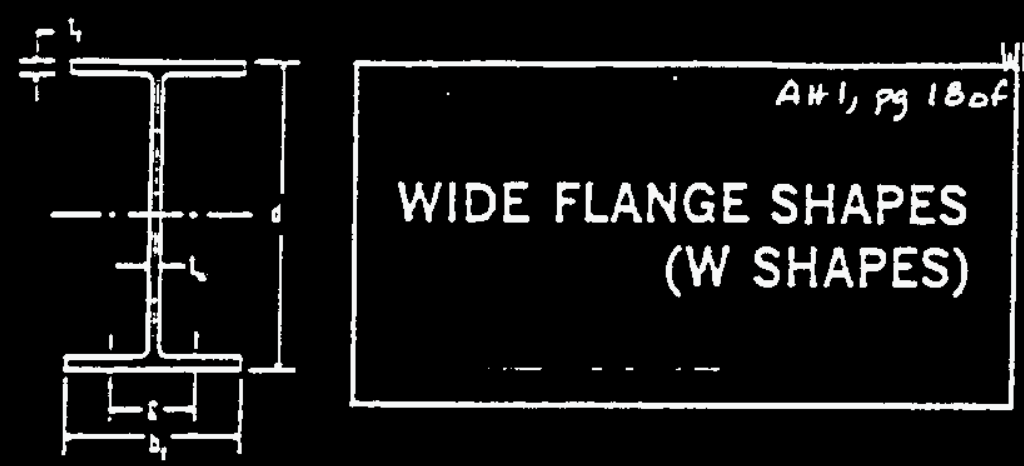

$H C-S P-S M E D A-016$, RaY, O

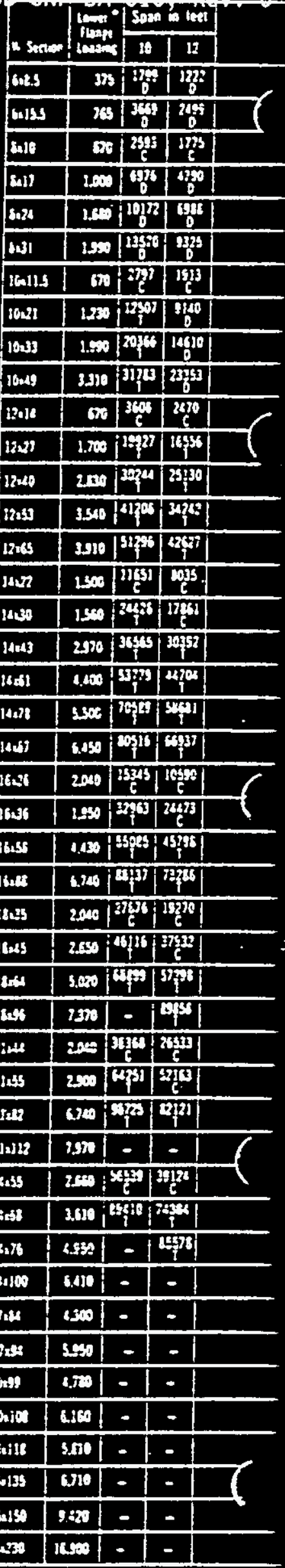

\begin{tabular}{|c|c|c|c|c|c|c|c|c|c|c|c|c|}
\hline \multirow{2}{*}{ 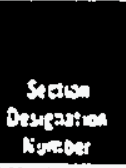 } & \multirow{2}{*}{$\begin{array}{c}\text { Dopin } \\
\text { setion } \\
\vdots \\
0\end{array}$} & \multirow{2}{*}{ 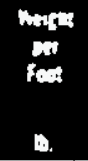 } & \multirow{2}{*}{$\begin{array}{c}\operatorname{los} \\
\sin \\
1\end{array}$} & \multirow{2}{*}{ niminos } & \multirow{2}{*}{$\begin{array}{l}\text { rant } \\
\lim _{1}\end{array}$} & \multirow{2}{*}{$\begin{array}{c}\text { Mange } \\
\text { rimsimes } \\
\text { in } \\
\text { in }\end{array}$} & \multirow{2}{*}{ then } & \multirow[b]{2}{*}{$\frac{1}{\lambda}$} & \multicolumn{3}{|c|}{ 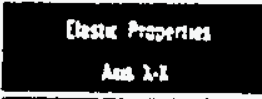 } & \multirow{2}{*}{ 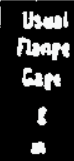 } \\
\hline & & & & & & & & & 1 & $\begin{array}{c}S \\
-1\end{array}$ & $i$ & \\
\hline Wonts & 8.83 & 23 & 231 & 0.170 & 3.580 & GIX & 6.1\% & $\overline{3.53}$ & $\overline{\text { IIII }}$ & $\lg$ & 2.83 & 23 \\
\hline 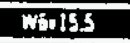 & 60. & Bb. & 65 & 0.235 & $\operatorname{s.c5}$ & 0.325 & 1512 & 3.72 & 30.1 & 100 & 235 & $j_{h}$ \\
\hline 52310 & 7.50 & 1000 & 25 & 0.170 & $3 . \mathrm{gm}$ & 0.00 & $0 . \mathrm{fit}$ & 5.6 & 302 & $7 w_{0}$ & 5.28 & $2 \pi$ \\
\hline wand & 10 & 120 & 59 & 0.230 & 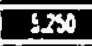 & 0.35 & 1.31 & GS & $\bar{x}$ & $\overline{B D J}$ & 3.3 & 24 \\
\hline Kand & 7.93 & 201 & 7.65 & 0.245 & $E D$ & 0356 & 233 & j.07 & $\sqrt{2.25}$ & 5203 & 134 & $3 n$ \\
\hline mall & 8.00 & 310 & 0.12 & $0.5 \pi$ & $\operatorname{lom}$ & 0.015 & $20 x$ & 251 & 110 & hik & 3.07 & sh \\
\hline W:osliss & 9.77 & 115 & 1.5 & 0.00 & 956 & 000 & 640 & 2223 & 5 & 70.5 & $3 \Omega$ & 24 \\
\hline $7302 \pi$ & 9.50 & 21.0 & 0 & 0500 & 5.50 & 0300 & 1.33 & 3.6 & 107 & 215 & 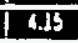 & 25 \\
\hline Tinas & 9.75 & 30 & 3.n1 & 0.21 & $7 M$ & 645 & 34 & $2 \pi$ & Din & 325 & 650 & 3 \\
\hline$\pi 1006$ & 1000 & 4in & $\overline{10.1}$ & 0350 & 10.000 & $\cos x$ & 3 & 1.8 & 273 & 5.6 & d! & 5 \\
\hline 0.2030 & I1.51 & BII & $6 x$ & $0.1 \%$ & 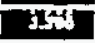 & $\operatorname{sen}$ & 0.60 & 16.46 & 8 & 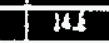 & $\pi$ & $2 \sqrt{x}$ \\
\hline (122031 & 7IS & 210 & $\omega b$ & $\sqrt{2235}$ & bIST & 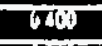 & 34 & 85 & 20 & 32 & $5,0 \%$ & $\sqrt{n}$ \\
\hline Nif8 & $\pi n$ & Iid & III & $a x$ & 2000 & d.55 & 4.125 & $\mathrm{ZW}^{2}$ & 30 & 189 & 5.17 & $\ln _{n}$ \\
\hline$\pi 12553$ & 12.0 & 530 & 18.5 & 0,295 & 50.60 & 0.536 & 3.20 & 203 & 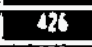 & 70.7 & 22 & 5 \\
\hline 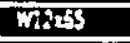 & 12.12 & 650 & 19.1 & 0.50 & 12.000 & $8 \times \omega^{\circ}$ & 1221 & 1.5 & EAt & 80 & 233 & In \\
\hline$N i \sqrt{2 B}$ & 18.72 & 20 & 8 & 0230 & hoon & $\overline{0.535}$ & 1.673 & 8.5 & $I I I$ & 29 & 55 & 24 \\
\hline 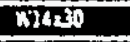 & 138 & 30 & 28 & 0.376 & 6.253 & 035 & 2.576 & 35 & 20 & 49 & $3 . \pi$ & 3 \\
\hline Kion:13 & Dु. & 430 & 12.0 & 0306 & 8.000 & $\overline{0.23}$ & 8526 & 328 & 857 & bis & 150 & $3 \%$ \\
\hline N16251 & I3.91 & 매, & in & 0370 & Do.m & $\delta \overline{L S 3}$ & 6,30 & 2.16 & ब1 & 525 & 1 III & $\overline{94}$ \\
\hline K14t2x & 10.05 & 200 & 2as & 0423 & 123000 & 0.711 & 8.616 & 2.63 & 8 & 123 & 6.66 & 53 \\
\hline nent? & 10.0 & ino & 3.0 & 0.420 & $16 \sin$ & 0.53 & 9.576 & 1.00 & F; & 19 & 6.36 & 5187 \\
\hline 129623 & 16.55 & $\overline{x .0}$ & 707 & 0230 & $\sin$ & 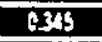 & $2 \times 1$ & 8.5 & 300 & II: & 6.53 & 24 \\
\hline N68236 & 15.65 & 30. & 20.6 & 0.21 & 6.52 & 0628 & 298 & 83 & 47 & XI & 6.50 & 318 \\
\hline n.6.68 & IE.L. & 50 & III] & 0.00 & 8.6 & a.M3 & 5.039 & 211 & 79 & 248 & 6.2 & sh \\
\hline KIGed & 10.16 & 20 & 81 & $\cos x$ & IIf:2 & 0.80 & g.ju & $1.7 n$ & $\operatorname{lm}$ & $\sqrt{151}$ & 60 & 96 \\
\hline Waks & $10 \pi$ & 39.0 & 103 & 0 & 5 & 0,62 & 258 & 6.6 & 5 & $5 x$ & 7.85 & 34 \\
\hline nifors & 12.0. & 480 & $\overline{122}$ & and & $m w_{1}$ & $O D_{5}$ & i.j]1 & 6.5 & 80 & $\pi$ & 730 & 13 \\
\hline Nithos & 170 & म. & III & 0.013 & WII & 0.65 & 5 & 25 & 160 & III & 7.6 & 5 \\
\hline Witis & $\pi n$ & 50 & 52 & DSL & $11 r^{2}$ & Qxin & $\overline{g .01}$ & II & 100 & 15 & 8.70 & 5 \\
\hline (23154 & $20 x$ & uno & {$[3$} & 0.30 & 65 & D[S3] & $2 \pi$ & $7 x$ & DI3 & a & 6.67 & 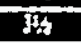 \\
\hline C.d1255 & 200 & 50 & $\sqrt{13}$ & 0.376 & DIS & 0.52 & 420 & 6.5 & 150 & 110 & 84 & $s_{n}$ \\
\hline ne252 & $\mathrm{gan}$ & DD & 213 & 0.05 & $\overline{\mathrm{L} 3}$ & Qwis & 7.520 & $2 \mathrm{at}$ & then & 10 & $\mathrm{LF}$ & sh \\
\hline K21RI12 & 21.0 & 12.0 & $\mathfrak{3 0}$ & 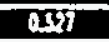 & If.6 & $\alpha \sqrt{35}$ & 1958 & is & 730 & 25 & $8 . S 2$ & $5 m$ \\
\hline$\sqrt{1221553}$ & 235 & $m$ & 10 & 035 & 7.60 & एक्य, & 3 3.5. & 6.5 & 130 & III & 9.10 & 3 \\
\hline$\sqrt{32+25}$ & $2 \mathbf{n}$ & $2 x$ & 200 & 0.16 & $2 \mathrm{Et}$ & 283 & $2, n 3$ & 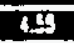 & 100 & $1+3$ & 9.5 & (5948 \\
\hline $18291 \pi$ & $2 m n$ & $\pi 0$ & 21 & 0000 & 8926 & C.C3 & 6.22 & 3.3 & 210 & wb & 96 & 54 \\
\hline (2001000 & 200 & 100 & 45 & 0.00 & 2,000 & 0.723 & 8.300 & 2.2 & 300 & 83 & 160. & 54 \\
\hline nind & 3.. & 20 & 24 & 0.26 & 5 Sit & 0.63 & 6.51 & 42 & $2 \times 3$ & 243 & 10.7 & $\bar{G}$ \\
\hline nzitas & 20.9 & 20 & 27.1 & is<re & 9900 & 076 & 928 & 261 & 2350 & 213 & 16.9 & 5 \\
\hline $\cos 20$ & 34 & sino & 2.1. & 0.572 & 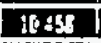 & 0.60 & $\overline{x y 3}$ & 823 & 100 & 30 & iil & \$s \\
\hline WJohid & 29.8 & Exto & $3 \mathbf{3 . 4}$ & $\sin 2$ & 10102 & $C . T^{2}$ & 7.45 & 37 & $4 x$ & 30 & 1118 & Bh \\
\hline KEBSIII & 53 & IIII0 & 3 & OSES & 111.4 & 0.29 & 2.873 & in & 50 & 35 & 1330 & 5 \\
\hline Nentis & 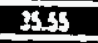 & 1560 & $\boldsymbol{m}$ & $0 \leq 41$ & $111 \times 3$ & 0.63 & 2.4 & 3.18 & 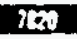 & 40 & 118.0 & 54 \\
\hline F3:1E? & 34 & 150 & 43 & a.s. & 18.92 & 590 & 13.53 & 3.11 & $\operatorname{cas}$ & सू & $\overline{163}$ & th \\
\hline nestanin & 22.3 & $23 x 0$ & [2] & 0.701 & $16 m$ & 1.30 & 20.753 & 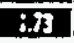 & $\operatorname{Exp}$ & $x$ & 169 & $\overline{42}$ \\
\hline
\end{tabular}

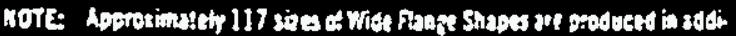

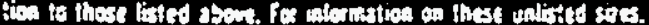

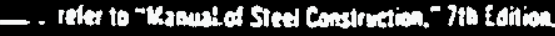

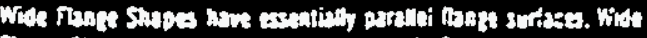

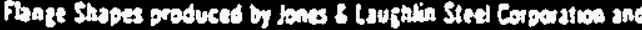

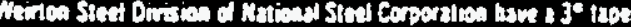

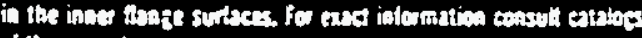
of thate voducers

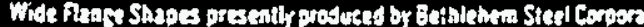

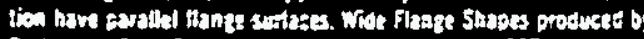

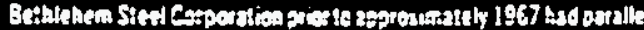

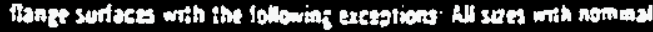

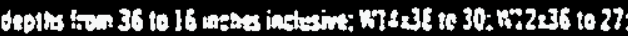

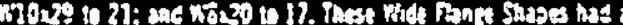

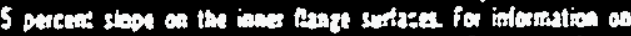

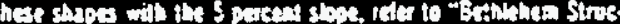

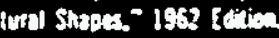

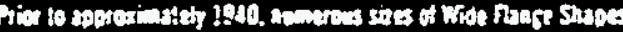

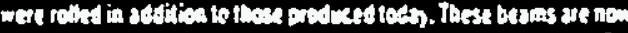

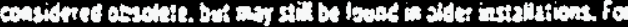

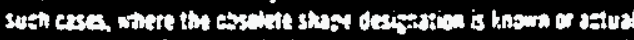

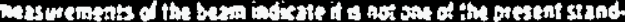

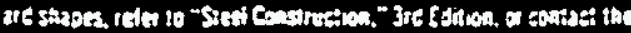
Yeat oftice. methincess: $\sin$ oses 6

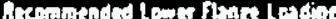
on pis of whents 
$\underset{0}{8}$

176

$121 / 25$

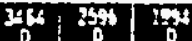

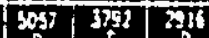

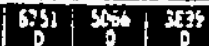

$\operatorname{lin} \mid$ 这3

की

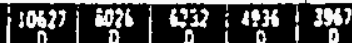

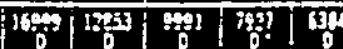

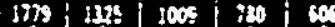

i2406 54507000

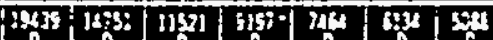

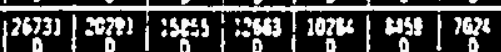

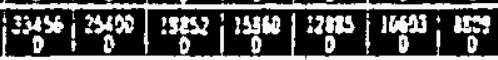

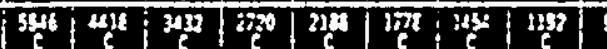

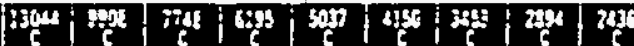

|245\%

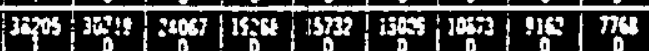

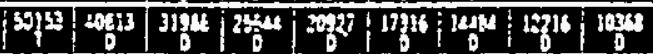

|5:313 कent

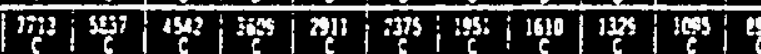

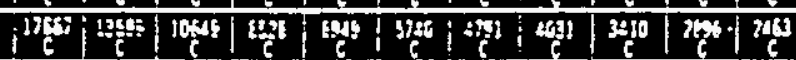

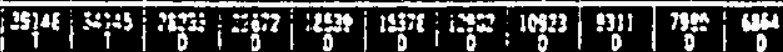

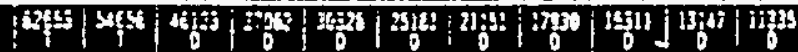

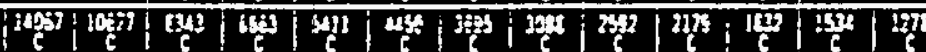

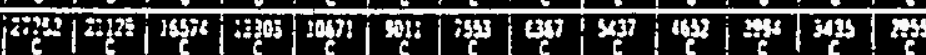

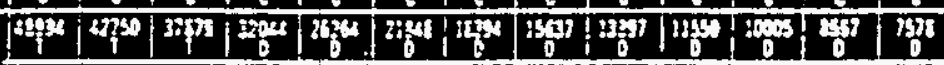

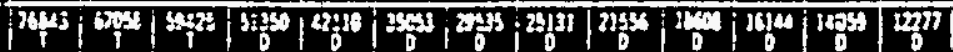

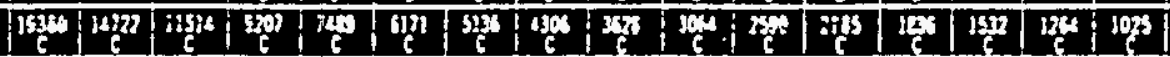

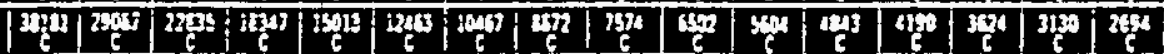

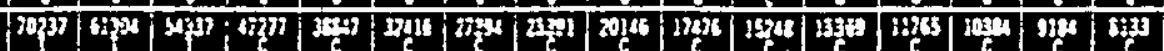

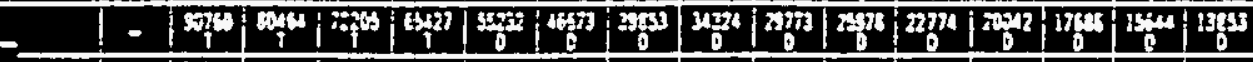

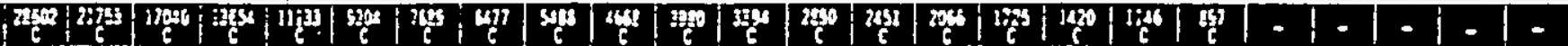

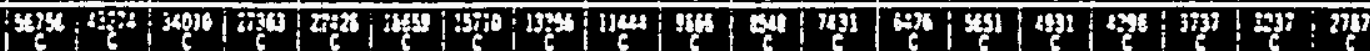

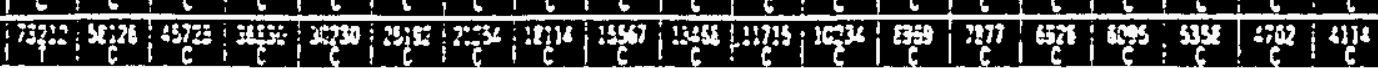

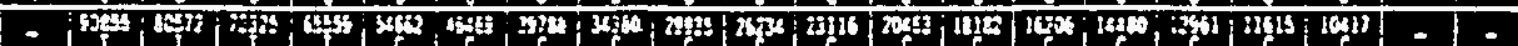

;

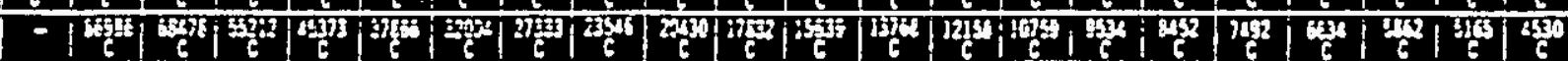

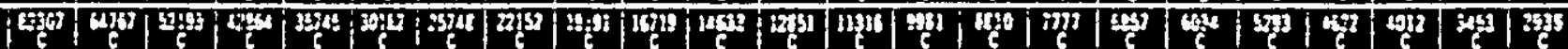

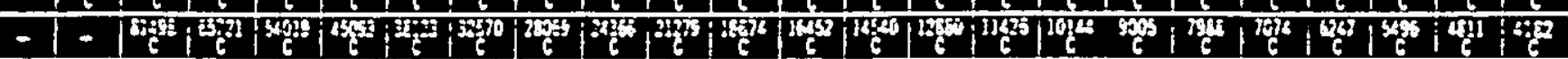

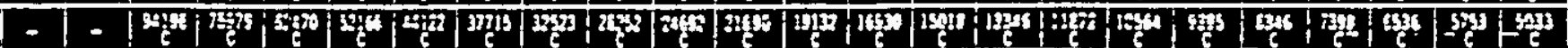

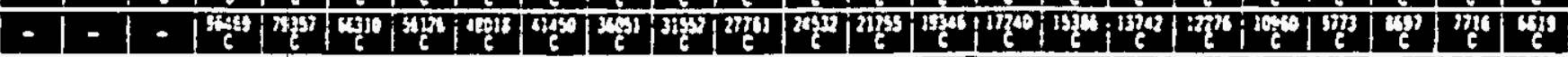

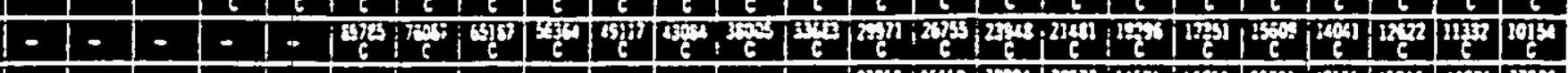

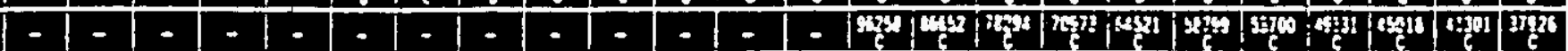




\section{DESIGN ANALYSIS}

client Westinghouse

subject Alternate Analysis Check of Caics. by Harry Gotte of The Bartholomew Co. Inc. for the 305 Bldg. Bridge Crane Mod.

Location 305 Building

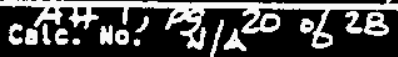

Revision 0

Page No. 1 of

wo/sob No. LEI12

Dore $9 / 20 / 95$

cheeked 9/27/95

By Mark Axup

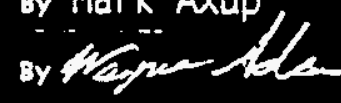

Revised

Note: Section numbers shown correspond to section numbers on original calculation by Harry Gotte (H. G.) of The Bartholonew Co.

2. Bridge girder (W14x61, ref. owg. H-4-101657, sht. 1 of 3 )

Design loading and stress analysis for 2 ton bridge girder hoist \& trolley.

\section{Sesiqu Londing:}

Vartical: Lifted live Loed * $4000.0 *$

hoist \& Twally : $\frac{1145.0^{*}}{5745.0^{*}}$ - Sue Sudin 1.0 of Ho. Cale. $10 \%$ impact $\frac{5,4.5}{5659.5} *$ Lise Setwai AH.2

whed load $\frac{2895.5}{4}=14,4.9+\operatorname{san} 1+5.0^{\circ}$

Lainal LL-kist itrollen $=3145.0$

wherlond $\frac{5145.0}{4} \cdot 12520.3^{4}$

Alse Setini 14.3

Laterad teres/mal.

$1286.3(0.20) \cdot 257.3^{*}$

$\operatorname{san} 20.0^{*}$

Lacitudined max. Lond/quides $2(1+5.0)=2830.0^{4}$

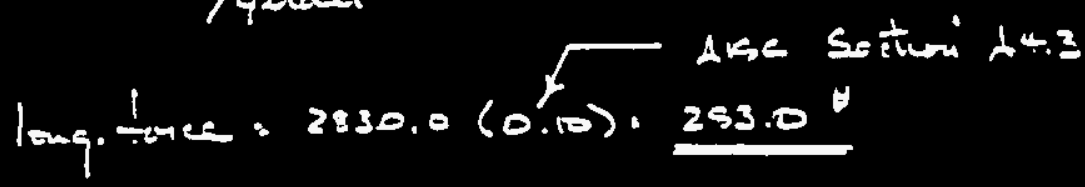




\section{DESIGN ANALYSIS}

client Westinghouse

subjeet Alternate Analysis Check of Calcs. by Harry Gotte of The Bartholomew Co. Inc.

for the 305 8idg. Bridge Crane Mod.

Location 305 Building cite. NT. " $N \mathrm{~A}^{21}$ of 28

Revision I

Page No. 2 of

wo/ Job No. LE112

Dose 9/20/95 By Mark Axup

cheeked $9 / 27 / 15$

Revised $12 / 7 / 65$ by

2. Bridge girder (cont'd.)

\section{stuas Anahis:}

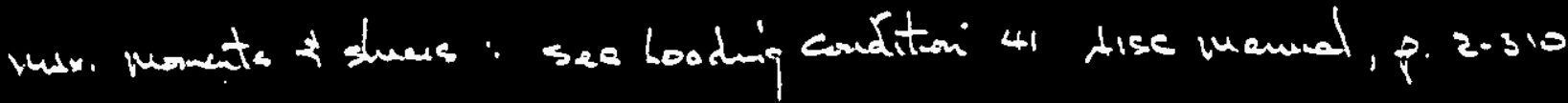

$a=3.17^{\prime}$. See dwip. H.4.101457 sh. $10+3$

L. $31.0^{\prime}-\operatorname{sen} d u g$. $H \cdot 4 \cdot 101654$

$3.17<0.586 l_{1} 18.17^{\prime} \therefore m_{\text {mile }}$ oceurs unden lord

Vatied

$$
e_{x} 1 / 2\left[31.0 \cdot \frac{3.17}{2}\right]=14.11^{\prime}
$$

$$
\begin{aligned}
& 14.71^{\circ} \quad 3.17^{\circ} \quad 13.12^{\circ}
\end{aligned}
$$

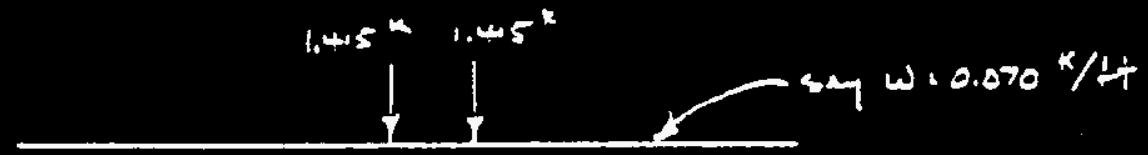

$$
\begin{aligned}
& \begin{cases}R_{L}=2.427^{k} & R_{E}=2.573^{k}\end{cases} \\
& R_{R}:\left[0.070(31.0)^{2.1 / 2}+1.4 .5(14.71+17.85)\right] / 31.0=2.573^{K} \\
& R_{i}: 0.070(31.0)+2(1.415)-2.573=2.427^{k} \\
& \mu_{x_{k y}}=2.427(14.11) \cdot 0.070(14.11)^{2 / 2}=28.13^{1.4} \\
& R_{\max }=1.415\left[2 \cdot \frac{3.17}{31.0}\right]+\frac{0.070(31.0)}{2}=3.770^{K}
\end{aligned}
$$




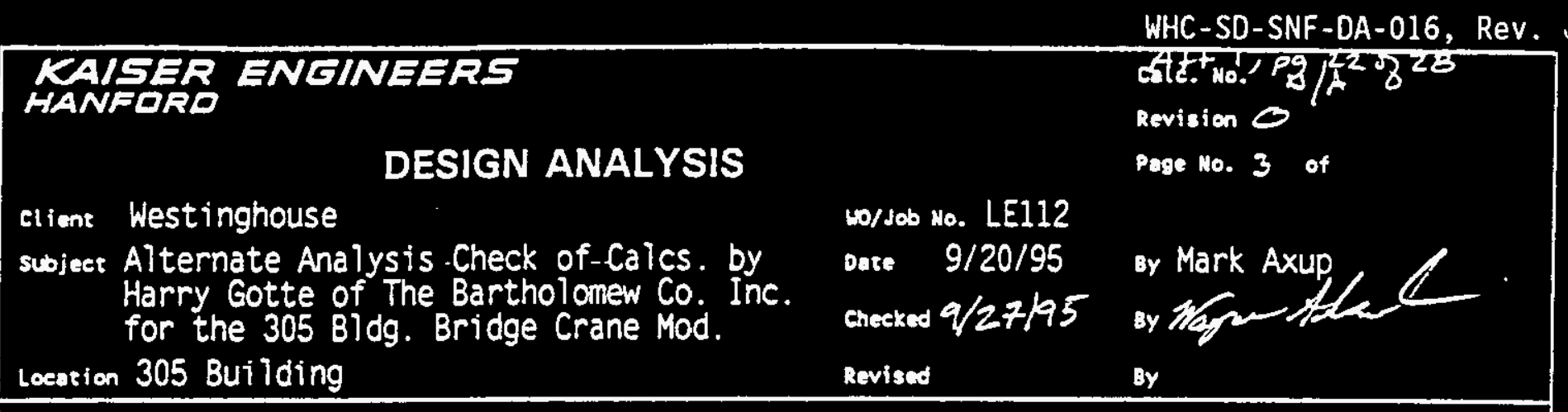

2. Bridge girder (cont'd.)

Stwes Andysis ' (contd).

Latered

$$
m_{7_{\text {max }}}=\frac{0.260}{2(31.0)}\left[31.0-\frac{3.11}{31.0}\right]^{2}=4.000^{1-k}
$$

wisxel Secton Properties:

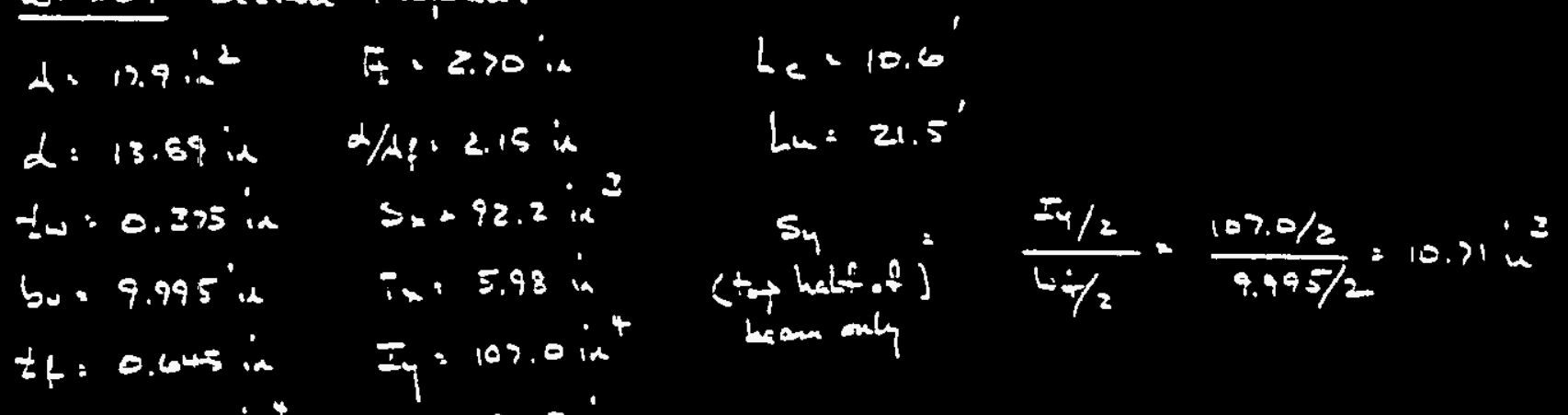

Ix: 600.0 in if if 2.45 in

$$
\begin{aligned}
& L / i_{i}=\frac{31.0(12)}{2.70}=137.8>\sqrt{\frac{510 \times 10^{3} \mathrm{Cb}}{F_{y}}}=119.02 \\
& F_{b x}=\frac{170 \times 10^{3} \mathrm{cb}}{\left(f / i_{6}\right)^{2}}=\frac{170 \times 10^{3}(1.0)}{(137.8)^{2}}=8.95^{\mathrm{ks1}} \\
& F_{x} \cdot \frac{12 \times 10^{3} \mathrm{Cb}}{l d / \lambda f}=\frac{12 \times 10^{3}(1.0)}{12(31.0)(2.15)}=15.00^{\mathrm{ks}}+U_{\text {se }}
\end{aligned}
$$

KEH $0037.00(06 / 92)$ KEF055

A- 40 
KAISER ENEINEERS

HANFERD

\section{DESIGN ANALYSIS}

client Westinghouse

subjeet Alternate Analysis Check of Calcs. by Harry Gotte of The Bartholomew CO. Inc. for the 305 Bldg. Bridge Crane Mod.

Location 305 Building cal:

Revision

Paill Ne. 4 of

2. Bridge girder (cont'd.)

stuess Analysis: (Conti.)

the louge stuess

$$
\begin{aligned}
& \frac{f}{6 x}=\frac{25.13(12)}{92.2}=3.461^{k 81} \\
& f_{b y}=\frac{4.00(12)}{10.71}=4.482^{\mathrm{kg} 1} \\
& \frac{1}{\log .} \frac{0.283}{(1.995)(0.645)}=0.044 \mathrm{kst} \\
& f_{\text {total }}=8.187^{k s 1}<150^{k s 1}=k
\end{aligned}
$$

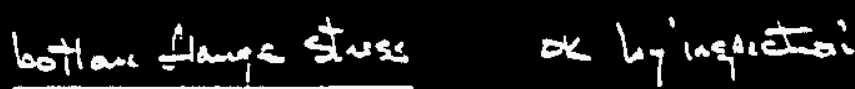

elued biflection: Consunatiely, assume concentinted load of $2 \times 1.45=2.83^{K}$ acts $\&$ anter.

$\Delta \cdot\left[\frac{5(0.070) 31.0^{+}}{394\left(29 \times 10^{3}\right) 640}+\frac{2.83(31.0)^{3}}{48\left(29010^{3}\right) 640}\right] 1729 \cdot 0.2419^{\circ}=L / 1538$ oK 
KAIGER ENEINEERS

HANFDFB

\section{DESIGN ANALYSIS}

client Westinghouse

subject Alternate Analysis Check of Calcs. by Harry Gotte of The Bartholonew Co. Inc. for the 305 Bldg. Bridge Crane Mod.

Leation 305 Building

6. Monorail Analysis: 2 tom eapoeitin

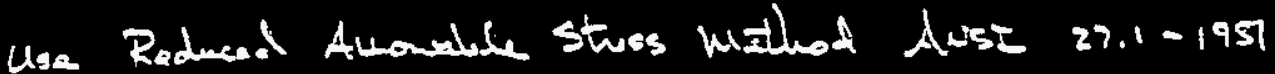

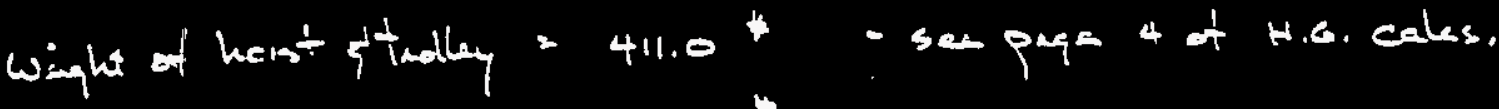

$$
\text { Litt: } 4000.0^{*}
$$

Imiact $15 \%$. Lift $=\frac{600.0^{*}}{5011.0^{*}}-$ Su Sictui 2.3 .4

Awowshle sthesses: $F_{b}=0.2(58.0)=11.6^{\mathrm{ks}}$ section 3.1 .1

$$
\text { Tension (corituds) }
$$

$\operatorname{Tay} 55 \times 18 . t$

Soctim Paninios:

Sx. $14.4 i^{3}$

$I_{x}: 57.6$ in $^{4}$

$T_{E}=0.94 \mathrm{is}$

$2 / A_{t}: 4.90$

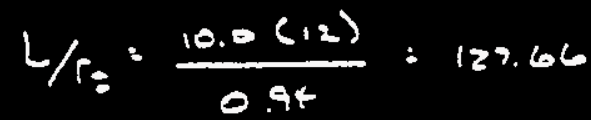$$
\overline{F b}_{x}: \frac{170 \times 10^{3}(1.0)}{(127.66)^{2}}=10.43^{\mathrm{ks1}}
$$

$F_{y_{x}}=\frac{12 \times 10^{2}(1.0)}{10.0(12)(4.20)}=21.28^{\mathrm{ks} 1}$

$24 x$

mas cth

chect stues: $f_{6}: \frac{12.15(12)}{14.4}=10.65^{k=1}<11.0^{k 81}$ or

check defloctioi:

$$
\Delta=\left[\frac{5.011(10.0)^{3}}{48\left(29 \times 10^{3}\right) 57.6}+\frac{5(0.02)(10.0)^{4}}{38+\left(29 \times 10^{3}\right) 57.6}\right](728=0.110)^{11}=5 / 1084 \text { or }
$$


WHC-SD-SNF-DA-016, Rev.

KAISER ENEINEERS

HANFERE

DESIGN ANALYSIS

ctient Westinghouse

subject Alternate Analysis Check of Calcs. by Harry Gotte of The Bartholomew $\mathrm{Co}$. Inc. for the 305 Bidg. Bridge Crane Mod.

Loeation 305 Building calc. Ho. N/A9 25$\}^{28}$

Revision $O$

Page No. 6 of

wo/Job No. LEI12

oore 9/20/95 _.. By Mark Axup

cheeked $9 / 27 / 95$

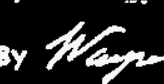

Revised

By 8. Bridge Girder Analysis for Underhung Monorail System - Kew slave gindu ondy
(witkal)

Dosian Loadin:

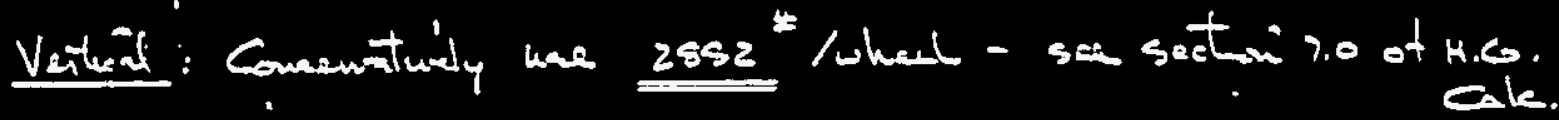

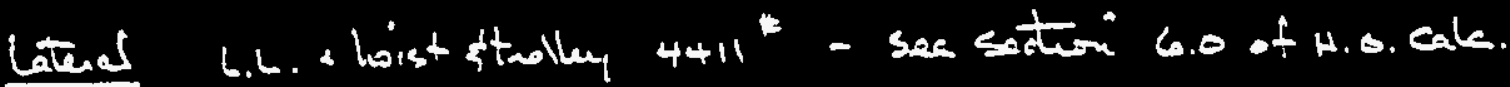

$$
\left.\begin{array}{c}
111 \\
30 \\
288 \\
323
\end{array}\right\} \text { Mine, see sietni } 7.0 \text { ot H.G. }
$$$$
\text { Latiel fure/when }=\frac{910 I}{2}(0.20)=516.3^{*}
$$

Assume ondy slace ginder wosists

$3920.0^{*}$

Latad loed. $\therefore$ dinid by 2

inglak ot 4

Lmaituding max. Load/gide $=2(2082)=5764$

lomitudinat ines: $5764.0(0.10)=576.4 \%$

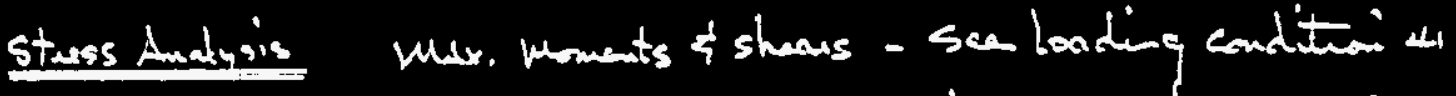
dise Mamal, $\rightarrow 2-310$

a. $5.0^{\circ}$ - Susatuin s.0 H.4.Cale.

$1 \cdot 31.0^{\prime}$ - Sud dig. H.4-101654

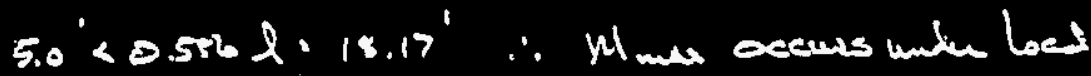

$$
\epsilon_{x}=1 / 2\left[31.0-\frac{5.0}{2}\right]=14.25^{\circ}
$$




\section{DESIGN ANALYSIS}

cliens Westinghouse

subjeer Alternate Analysis Check of Calcs. by Harry Gotte of The Bartholomew Co. Inc. for the 305 Bldg. Bridge Crane Mod. Lecation 305 Building wo/sob No. LE112

Date $9 / 20 / 95$

cheeked $9 / 27 / 95$ Revised $12 / 7 / 95$

Page No. 7 of

8. Bridge Girder Analysis for Underhung Monorail System - New slare ginde only Stanss Analysis: (comid.) ientical

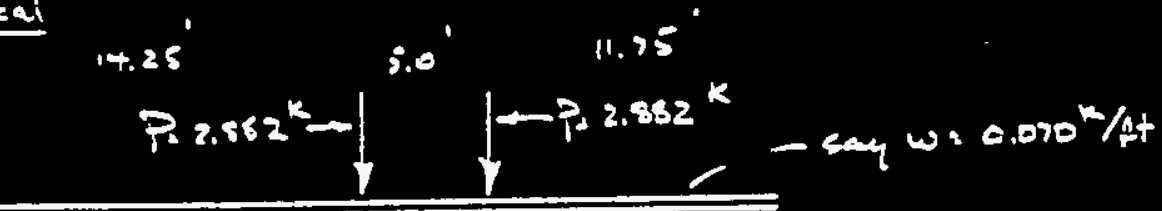

$R=\left[0.070(31.0)^{2} / 2-2.882(14.25-19.25)\right] 1 / 31.0=4.199^{k}$

$R_{L}=0.010(31.0)+2582(2)-4.199=3.735^{K}$

$M_{x}=3.735(14.25)-0.070(14.25)^{2} \frac{1}{2}=46.12^{1-k}$

$R_{\text {max }}=2.862\left[2-\frac{5.0}{31.0}\right]+\frac{0.070(31.0)}{2}=6.384^{k}$

(by ingietsoni)

Latuel

$$
m_{\text {max }}=\frac{0.520}{2(31.0)}\left[31.0-\frac{5.0}{2}\right]^{2}=6.81^{1 \cdot k}
$$

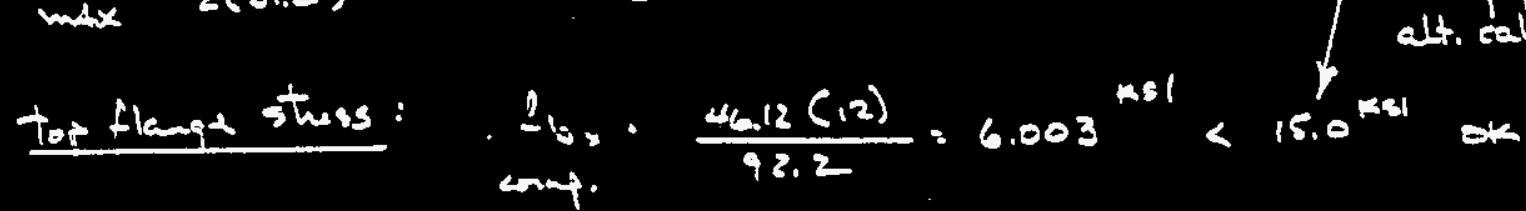

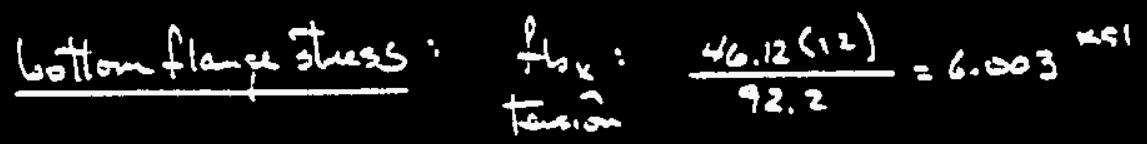

$$
\begin{aligned}
& \frac{1}{6 y}=\frac{6.01(12)}{10.71}=7.630^{\mathrm{ks} 1}
\end{aligned}
$$

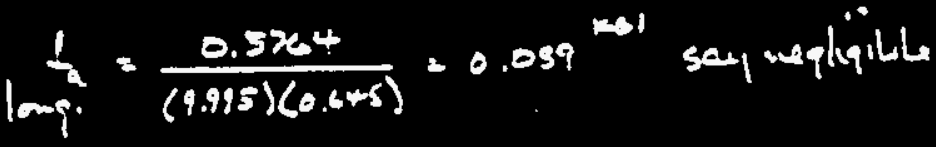


KAISER ENGINEERS

HANFDRE

DESIGN ANALYSIS

client Westinghouse

subject Alternate Analys is Check of Calcs. by Harry Gotte of The Bartholonew Co. Inc.

for the 305 Bldg. Bridge Crane Mod.

Location 305 Building

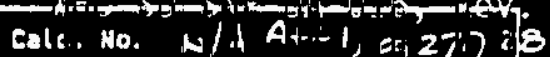

Revision !

Page vo. is a if

8. Bridge Girder Analysis for Underhung Monorail System

stress Avalyeis : (Contd)

botton Hange stuss: ched combind stress (contd.)

$f w .6 .003+7.630 \cdot 12.633$

Tonserisi

Par Aise $F 1.2,8 .(F+.5)$

$$
F_{V \text { indon }}=0.6(36.0): 21.6^{\mathrm{ks1}}>13.633^{\mathrm{ks1}} \text { ok }
$$

10. Simultaneous Girder Loads (wimbil)

Load case with underhung 2 ton monorail located directly under new column attached to existing bridge girder. Both monorail and 2 ton bridge hoist loaded to capacity.

Assumed that simultaneous lateral impact by the bridge hoist and the underhung monorail system is unlikely. Only lateral impact from the bridge crane hoist will be accounted for.

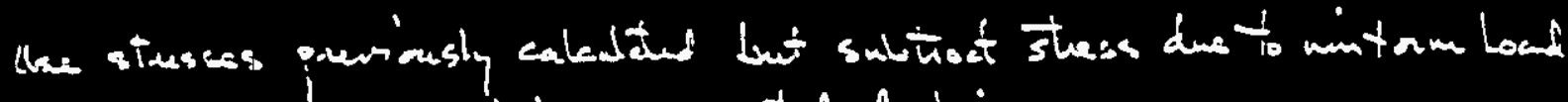
of $0.100 \mathrm{~K} / \mathrm{t}+\mathrm{s}$ so that it is not areonited fotwies

$\operatorname{lin}_{x} \times \frac{0.070(31.0)^{2}}{8}=8.409^{1-k} f f_{6} \cdot \frac{8.409(12)}{92.2}=1.094^{\mathrm{ksi}}$.

Sturses duato embing loading:

$$
\begin{aligned}
& \text { (3.4) (4. 7) }
\end{aligned}
$$

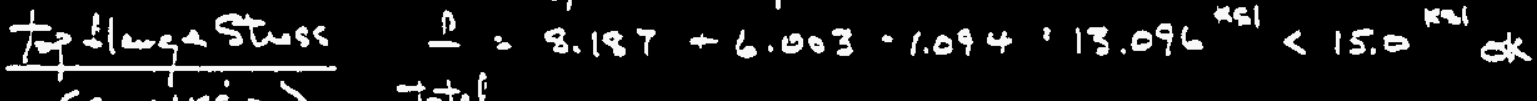

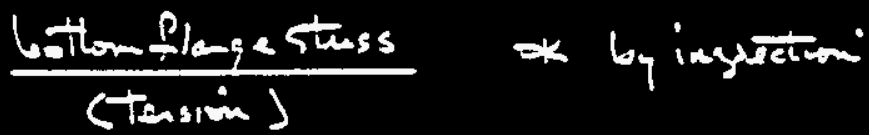


ctient Westinghouse

subjeet Alternate Analysis Check of Calcs. by Harry Gotte of The Bartholonew Co. Inc. for the 305 Bldg. Bridge Crane Mod. Location 305 Building wo/sob Mo. LE112

Date 9/22/95 By Mark Axup

cheeked $9 / 27 / 95$ sy Revised /2/7/95

\section{Original Girder Connection}

Chack coped soction tor shes.

mox. Exeign Shan: $\rightarrow 7$ of this attermet-check ealeulation

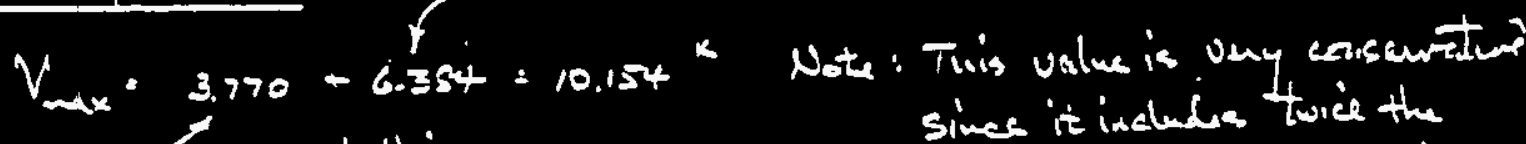

$$
\begin{aligned}
& \text { Cp. } 2 \text { of this } \\
& \text { allernate ethed } \\
& \text { caleubtion }
\end{aligned}
$$

Clude shou stress

Reminsing boom dopth : 7.375

$$
\begin{aligned}
& t_{\omega}=0.645 \\
& \frac{1}{-2} \cdot \frac{10.154}{(0.6+5)(7.375)}=2.135^{k 81}<0.4(36.0)=14.4^{k+1} \text { of }
\end{aligned}
$$

sheck Loal web yiald waig

Length of bearing = $12.5^{\circ}$

$$
f_{a}=\frac{10.154}{(0.645)(12.5)}=1.259
$$

kal

(aloug teab) $(0.645)(12.5)$

16. Nas Girds2 Connseion:

$$
V_{\text {man }} \cdot 6.304^{k}(\sec \text { dawan) }
$$

chode shem stures:

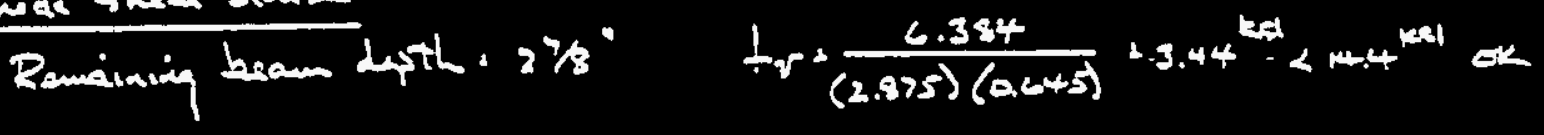
Local wab yialding ox by ingertani 
WHC-SD-SNF-DA-016, Rev. 0

Attachment 2:

Letter for 305 Building Crane Structure Analysis

by

Gary Wagenblast, WHC 


\section{CC: SA Dawson W/A-12A \\ RC Ingersoll W/B-103 GRW/LB}

Reference: Letter, C. R. Mllen to R. C. Ingersoll, same subject. doled July 27, 1983.

The 305 buildiny crane struc:Lure depicted on drawings 11-3-34a9)1 and II-3-34292 was analyzed as reyucsted in the reference intler.

The upper rails have the capacity to withstand one bridge crane having a capacity of 10 tons or two bridge crancs having a 5 ton capacity cich. The combination of one 10 ton bridge and onc 5 ton hridge, as proposed. would require modifications to the rail beams and modifications to all beam-to-column attachments.

The lower rails are adequate for the existing electromechanical manipulator bridge. The addition of a second manipulator bridge would require either a modification to the rail beans or physical barriers to assure a separation of 5 feet between hridges. Ho modifications to beam attachments would be required in cither case.

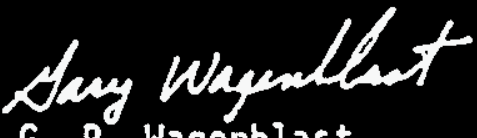

G. R. Wagenblast

Engineer

ina 


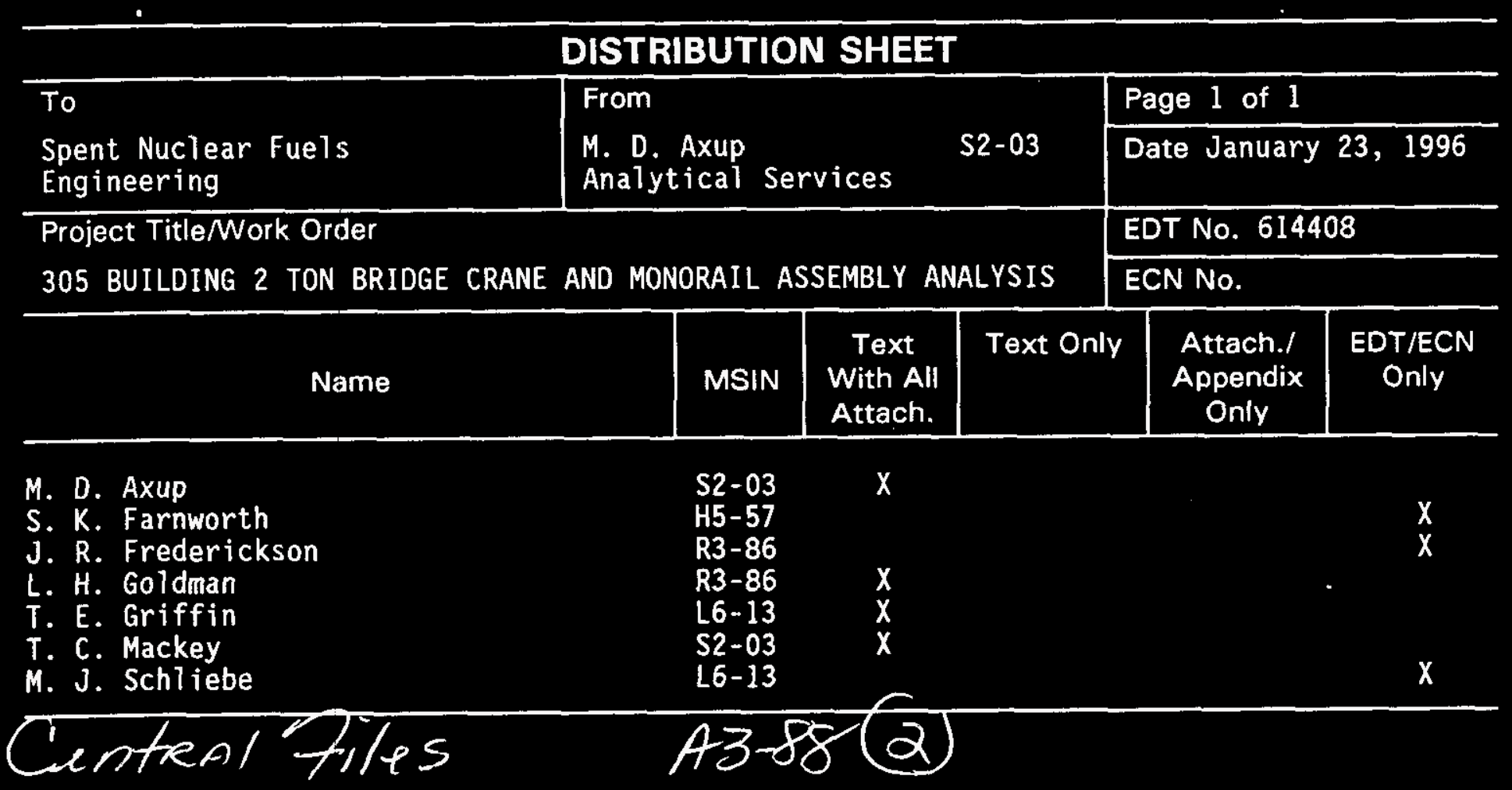

